\title{
The sub-arborescent lycopsid Omphalophloios feistmantelii (0. Feistmantel) comb. nov. emend. from the Middle Pennsylvanian of the Czech Republic
}

\author{
JIŘí BEK, STANISLAV OPLUŠTIL, JANA DRÁBKOVÁ \& JOSEF PŠENIČKA
}

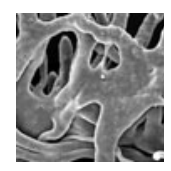

\begin{abstract}
About ninety compression specimens of sub-arborescent lycopsid Sporangiostrobus feistmantelii (Feistmantel) Němejc from the middle Westphalian strata of central and western Bohemia, Czech Republic, were studied. A new combination, Omphalophloios feistmantelii (O. Feistmantel) comb. nov. emend., is proposed and the original diagnosis is emended, mainly by new data concerning spores, sporangia, vegetative and reproductive parts. The basal vegetative part of the stem bears rhomboidal leaf cushions with bell-shaped leaf scars, although a larger part of the stem consists of a fertile axis bearing oval sporangia about 5-6 $\mathrm{mm}$ wide and $7-8 \mathrm{~mm}$ long. $O$. feistmantelii is estimated to be a plant of about 2 to $3 \mathrm{~m}$ in height of columnar habit sometimes once or twice dichotomizing in the fertile part of the stem. The fertile zone matured from bottom to top shedding first more than $20 \mathrm{~cm}$ long grass-like laminae and than ripened sporangia, leaving only pedicels on the naked axis (Puertollania-disarticulation stage). This suggests continuous reproduction from the time the plant reached the mature stage at the end of its life cycle. The older decorticated part of the stem displays the Knorria-type of preservation. In situ microspores possess large morphological variation and can be assigned to the genera Densosporites (Berry) Butterworth et al. and Cristatisporites (Potonié \& Kremp) Butterworth et al. In situ megaspores are of the Zonalesporites superbus-type. The stratification of sporangial walls is described from cuticle studies. O. feistmantelii is interpreted as a plant having an opportunistic life strategy and was able to colonize rapidly local habitats, particularly where there was limited competition, preferring peat and mixed peat-clastic swamps. $\bullet$ Key words: lycopsids, in situ spores, Omphalophloios, Sporangiostrobus, cuticle analysis, densospores, Superbisporites, palaeoecology, Pennsylvanian.
\end{abstract}

BeK, J., OPLuŠTIL, S., DRÁBKOVÁ, J. \& PŠENIČKA, J. 2015. The sub-arborescent lycopsid Omphalophloios feistmantelii (O. Feistmantel) comb. nov. emend. from the Middle Pennsylvanian of the Czech Republic. Bulletin of Geosciences 90(1), 227-279 (35 figures). Czech Geological Survey, Prague. ISSN 1214-1119. Manuscript received February 26, 2014; accepted in revised form October 22, 2014; published online January 21, 2015; issued January 26, 2015.

Jiři Bek, Department of Palaeoecology and Palaeobiology, Institute of Geology v.v.i., Academy of Sciences, Rozvojová 269, 16500 Prague 6, Czech Republic; mrbean@gli.cas.cz•Stanislav Opluštil, Faculty of Sciences, Charles University, Albertov 6, 12843 Prague 1, Czech Republic; oplustil@natur.cuni.cz・Jana Drábková, Czech Geological Survey, Klárov Prague 1, Czech Republic; jana.drabkova@geology.cz・Josef P̌̌enička, West Bohemian Museum, Kopeckého sady357/2, 30100 Pilsen; jpsenicka@zcm.cz.

Sub-arborescent lycopsids are important but quite rarely found Pennsylvanian plant fossils. Their general habit is roughly similar and all modern reconstructions show columnar or up to several times dichotomizing stems with sporangia arranged in fertile zones (Pigg \& Rothwell 1983, Wagner 1989, Drábková et al. 2004, Bek et al. 2008). Four main genera of Pennsylvanian subarborescent lycopsids are known; Omphalophloios White, Spencerites Scott and Polysporia Newberry (or its anatomically preserved equivalent Chaloneria Pigg \& Rothwell). Polysporia was monopodial whereas Omphalophloios and Spencerites were up to several times dichotomously divided (Němejc 1931, Wagner 1989, Drábková et al. 2004, Bek et al. 2008). Spencerites is monosporangiate while the genera Omphalophloios and Polysporia are bisporangiate.

Plants of these genera were important elements of Pennsylvanian peat-forming and clastic wetlands of the Euramerican province, however, their contribution to biomass is usually relatively minor (e.g. Phillips et al. 1974). Omphalophloios is considered the main producer of densospores, which dominated palynospectra of many Euramerican Pennsylvanian coals or portions thereof (Smith \& Butterworth 1967, Peppers 1996, Opluštil et al. 1999). Surprisingly remains of parent plants are only rarely found as compressions. Among few exceptions belongs the Puertollano Basin in central Spain and localities in central and western Bohemia, Czech Republic, where their fragments 
are preserved in volcanic ash bands intercalated in coals whereas mudstone in roof of the Lower Block Coal of the Illinois Basin is an excellent example of a rich occurrence of Omphalophloios in the North America.

Detailed studies of specimens from USA and Spain (e.g. Brousmiche-Delcambre et al. 1995; Wagner 1989, 1999; Wagner et al. 2003) led to a significant progress in our understanding to the morphology of this plant. On the other hand, comparably rich material collected in central and western Bohemia for more than one and a half centuries was last revised by Němejc in 1931. Since that time, however, new extensive material has been collected. Most of these specimens are preserved in volcaniclastics generated by volcanic ash fall, which buried vegetation in situ (e.g. Opluštil et al. 2007, 2009a, b). Simple taphonomy as well as rich material collected partly by two of authors (SO and JD) provide a wealth of information that can further contribute to better understanding to this conservative lycopsid plant. Specimens previously named Sporangiostrobus feistmantelii $\mathrm{O}$. Feistmantel are transferred to the genus Omphalophloios based on the re-examination of Brousmiche-Delcambre et al. (1995) who studied the type collection of Omphalophloios cyclostigma (Lesquereux) White. Brousmiche-Delcambre et al. (1995) demonstrated that Sporangiostrobus Bode is a junior synonymum to Omphalophloios. Diagnoses of Sporangiostrobus feistmantelii given by Feistmantel and Němejc were emended based on re-examination of the morphology of plants, sporangia and their cuticles and in situ micro- and megaspores of all known specimens. A new combination, i.e., transfer of the species to the genus Omphalophloios, is suggested here and the first reconstruction of the whole plant is illustrated.

\section{History of Omphalophloios}

The earliest known specimen of Omphalophloios is a fragment of vegetative stem described by Sternberg (1823) as Lepidodendron anglicus (Sternberg) Kidston. A fertile specimen, found in the Saar Basin (Germany), was for the first time described by Goldenberg (1856) as "eine Fruchtähre zu Sigillaria elegans". Slightly earlier, Corda in his unpublished manuscript provided a description of two forms of similar plants later re-described and illustrated by O. Feistmantel (1875-1976). He assigned Corda's specimens Embolianthemum sexangulare Corda to Sigillariostrobus cordai O. Feistmantel and Embolianthemum truncatum Corda to Sigillariostrobus feistmantelii O. Feistmantel.

Later White (1898) re-described several specimens determined previously by Lesquereux (1880) as Lepidodendron cyclostigma Lesquereux and assigned them to a newly established lycopsid genus Omphalophloios. White (1898) believed that Omphalophloios to be an arborescent lepidodendroid lycopsid that possessed two different kinds of leaf cushions and leaf scars.

In 1928, Bode described two fragments of the fertile parts of a plant of systematically uncertain position. He was able just to state that they are of pteridospermous or pteridophytic affinity. Therefore Bode (1928) established a new genus Sporangiostrobus and described his specimens from Orzesze in Upper Silesia, Poland as S. rugosus Bode and S. orzeschensis Bode.

In 1931, Němejc published an excellent paper on Omphalophloios (named by him as Sporangiostrobus), based on the study of Feistmatel's specimens and some new ones from the Pennsylvanian of the Czech Republic. He macerated micro- and megaspores from a single specimen and demonstrated the bisporangiate character of Omphalophloios for the first time. He was also the first to interpret Omphalophloios as trunks or branches with sterile and apical fertile zones and to prove that sporangia were attached to the stem and not arranged in cones. Němejc was sure that Omphalophloios was a lycopsid more primitive than Sigillariostrobus Hirmer and Lepidostrobus (Brongniart) Brack-Hanes \& Thomas.

Chaloner (1956, 1962) proposed two new species, Sporangiostrobus langfordii Chaloner and S. ohioensis Chaloner, from North America. He provided further morphological details and assigned in situ microspores to Densosporites (Berry) Butterworth et al. and in situ megaspores to Zonalesporites superbus (Bartlett) Potonié \& Kremp.

In 1970, Leisman published the first information about the anatomy of Sporangiostrobus and its in situ microspores [compared with the spore genera Radiizonates Staplin \& Jansonius, Vallatisporites Hacquebard, Cingulizonales Dybová \& Jachowicz, Cristatisporites (Potonié \& Kremp) Butterworth et al. and Densosporites] and megaspores (Zonalesporites superbus-type) based on permineralized (coal-ball) specimens from Kansas, USA. He also described the occurrence of primary xylem, an exarch siphonostele and distal ligules for the first time. These findings were the basis of an emended diagnosis (Leisman 1970).

Remy \& Remy (1975) proposed a new species, Sporangiostrobus puertollanensis Remy \& Remy, from the Stephanian of Puertollano, Spain. They described only microspores of the Densosporites-type and mentioned three layers of the sporangial wall and cuticles. They further suggested succulent or halophyte affinity. Partly disarticulated fertile zones with abscissed sporangia and retained pedicels were interpreted as vegetative stems and assigned to the genus Puertollania Remy \& Remy.

Later Wagner \& Spinner (1976), based on extensive collections from Puertollano provided the first description of the vegetative part of Sporangiostrobus under the name Bodeodendron Spinner \& Wagner. In 1989, Wagner pub- 


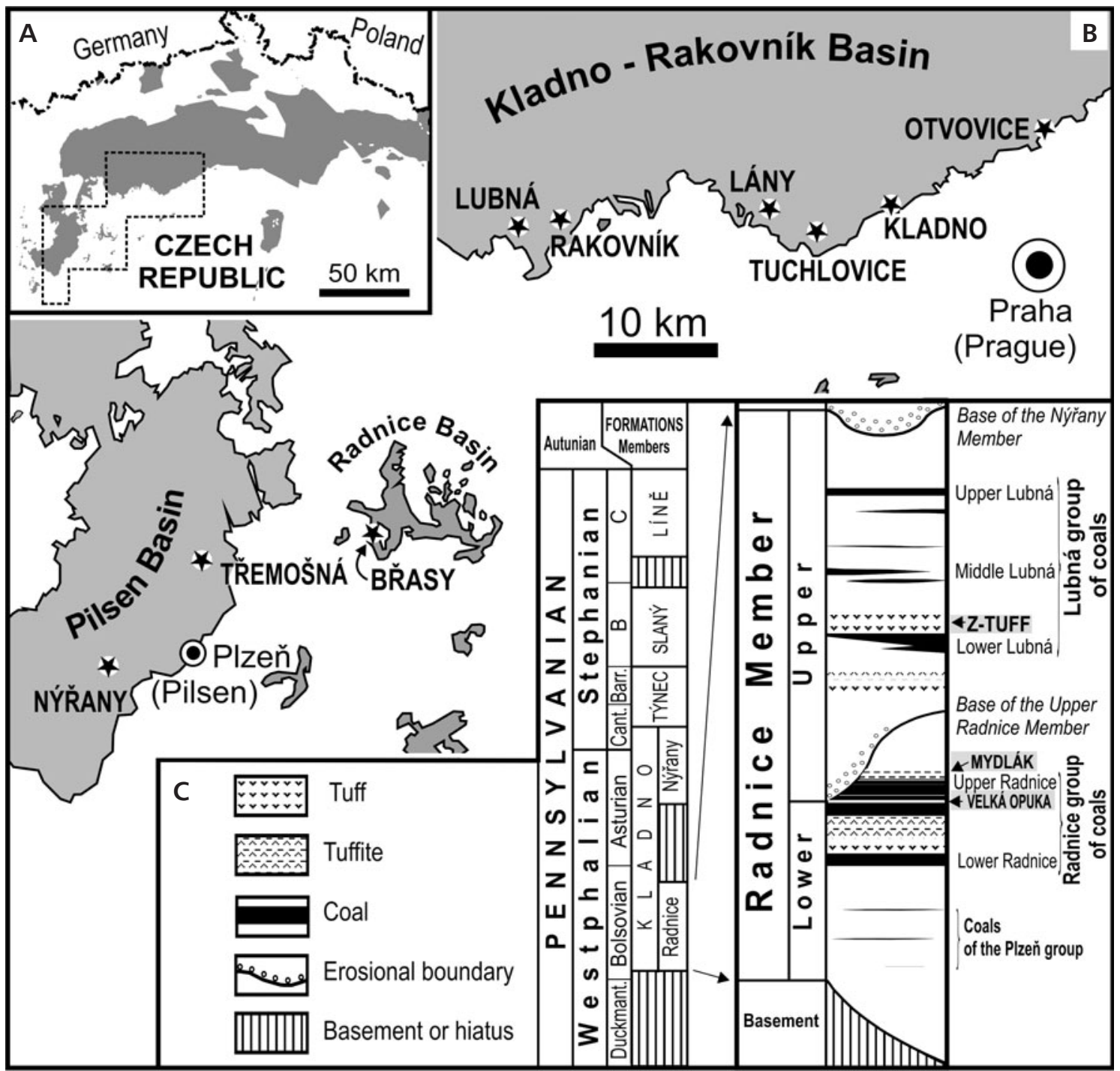

Figure 1. Geographic position of localities of Omphalophloios feistmantelii (O. Feistmantel) comb. nov. emend. in basins of central and western Bohemia, Czech Republic and their stratigraphical range. $\bullet$ A - distribution of Late Carboniferous continental strata in the Czech Republic. $\bullet$ B - localities of O. feistmantelii in the basins of central and western Bohemia. $\bullet \mathrm{C}$ - stratigraphy of the basins in central and western Bohemia and the occurrence of O. feistmantelii. Horizons providing Omphalophloios specimens are highlighted in grey.

lished an important paper based on thousands of specimens from Puertollano. He described various stages of disarticulation of Omphalophloios, the type of micro- and megaspores and stressed a direct correlation between Omphalophloios, high densospore counts and the durite content of the coals.

Bek \& Straková (1995) described the microsporangiate apical fertile area of $O$. feistmantelii from the Bolsovian of the Kladno-Rakovník Basin, Czech Republic, published the first SEM photomicrographs of in situ densospores, stressed the morphological variations of in situ densospores, which can be assigned to nine species of the genus Densosporites and one of the genus Cristatisporites. It is important to note that Bek \& Straková (1995, Fig. 7 herein) described different diameters of in situ densospores with those from microsporangia close to the apex being about half the diameters of in situ densospores isolated from microsporangia close to the base. The occurrence of peculiar circular objects full of microspores (Fig. 8A-D), which were macerated from microsporangia (Bek \& Straková 1995), is also very interesting.

Brousmische-Delcambre et al. (1995) provided a straight synonymy of Sporangiostrobus and White's (1898) lycopsid genus Omphalophloios based on compression specimens from Missouri, USA and on rich material from Puertollano, Spain. Brousmiche-Delcambre et al. (1995) macerated only megaspores of the Superbisporites-type from megasporangia, which had been interpreted by White in 1898 as leaf cushions. This showed that Sporangiostrobus and Bodeodendron and also Puertollania are 


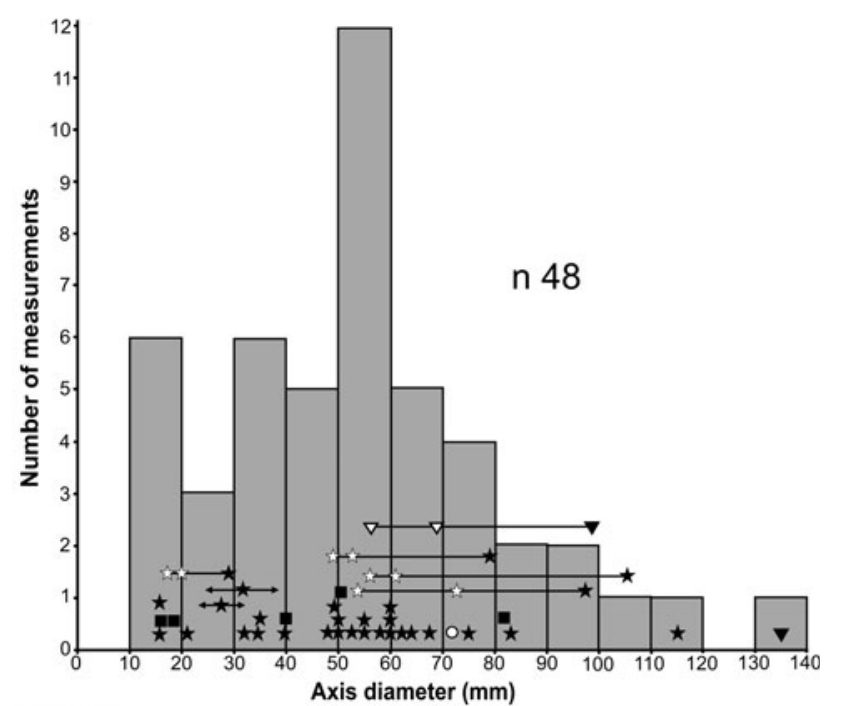

Fertile axis:

$\star$ cylindrical, $\nleftarrow \star$ conical with range of the diameter, $\leftrightarrow \hookrightarrow-\star$ dichotomizing ( $\star$ parent, radaughter axis) - fertile axis without sporangia (Puertollania)

Decorticated axis (Knorria)

ovegetative axis with leaf cushions $\quad \boldsymbol{\nabla}$ non-dichotomizing axis, $\nabla-\nabla \longrightarrow$ dichotomizing axis

Figure 2. Frequency of the occurrence of Omphalophloios axes of various diameters. Each symbol (or group of symbols connected by line) represent individual specimen. The position of symbols on horizontal axis indicates diameter of plant axis while vertical axis indicates number of measurements in a particular interval.

younger synonyms of Omphalophloios, which can be applied to both vegetative and fertile parts. However, it also significantly extends the geographical distribution of these primitive lycopsids.

In 1996, Coquel \& Brousmiche-Delcambre provided a more throrough description of in situ microspores of $\mathrm{Om}$ phalophloios, which they described as being of Cristatisporites-Densosporites-Cingulizonates-type.

Bek (1998) and Bek \& Opluštil (1998) described Omphalophloios from the Bolsovian of the Kladno-Rakovník Basin, Czech Republic, mainly its microspores, and emphasised variations of densospores, which they correlated with twelve species of Densosporites and five of Cristatisporites.

Wagner et al. (2003) also macerated in situ microspores of the Cristatisporites-type and in situ megaspores of the Zonalesporites-type from Omphalophloios puertollanense (Remy \& Remy) Wagner from the Stephanian C of Puertollano.

The latest results on the study of Omphalophloios was presented by Opluštil et al. (2010) who re-examined Bode's (1928) type specimens, Sporangiostrobus orzeschensis and S. rugosus, which represent fragments of fertile areas with microsporangia containing Densosporites. These two species, distinguished by Bode (1928) on differences in rough spore morphology, have been ascribed by later authors to intraspecific variation. Additional criteria that might justify retaining two different species were not found, since the cell pattern of the sporangial wall is essentially the same for all the species studied. Therefore, Opluštil et al. (2010) synonymised both species and proposed a new combination Omphalophloios orzeschensis (Bode).

\section{Stratigraphical range and geographic distribution}

The specimens of Omphalophloios feistmantelii have been found only at several localities in the Late Palaeozoic basins of central and western Bohemia, where they occur in three different stratigraphic horizons (in stratigraphic order): the "Velká opuka" tonstein intercalated in the Upper Radnice Coal, a mudstone (called "Mydlák") in roof of the Upper Radnice Coal and the Z-tuff bed in roof of the Lower Lubná Coal (Fig. 1). All of these stratigraphic levels are located in the Radnice Member of the Kladno Formation (late early Moscovian, lower Bolsovian). Most of the specimens are preserved in volcaniclastic rocks of the Velká opuka tonstein and the Z-tuff bed with a very few specimens preserved in mudstone.

\section{Material and methods}

The study material involves about 90 specimens stored in the collections of the National Museum (NM), Prague (34 cataloged specimens), Czech Geological Survey (CGS), Prague (about 35 mostly uncataloged specimens), Charles University, Faculty of Sciences (FS), Prague (two specimens) and West Bohemian Museum (WBM), Pilsen (18 specimens). The collection studied involves two of the type specimens first mentioned by Corda in his unpublished manuscript and later published and figured by O. Feistmantel (1875-1876). The latter author described Corda's specimens as Sigillariaestrobus Feistmanteli (species named after Karl Feistmantel, a palaeobotanist, coal geologist and father of O. Feistmantel) and S. Cordai. Only two from four specimens assigned by Feistmantel to S. Feistmanteli and re-described later by Němejc (1931) as Sporangiostrobus feistmanteli, were recently found. These are the specimens E974 and E6931, figured by Feistmantel (1875-1876) in plate LX, fig. 2 and fig. 1, respectively. The remaining two specimens assigned by Feistmantel to Sigillariaestrobus Cordai are missing. Nevertheless, Feistmantel's figures and description led us to the conclusion that the missing specimens represent only thicker axes of S. feistmanteli. Even Němejc (1931) assigned Feistmantel's specimens as well as his new collection to $S$. feistmanteli. We completely agree with this unification into one species since there are no other 

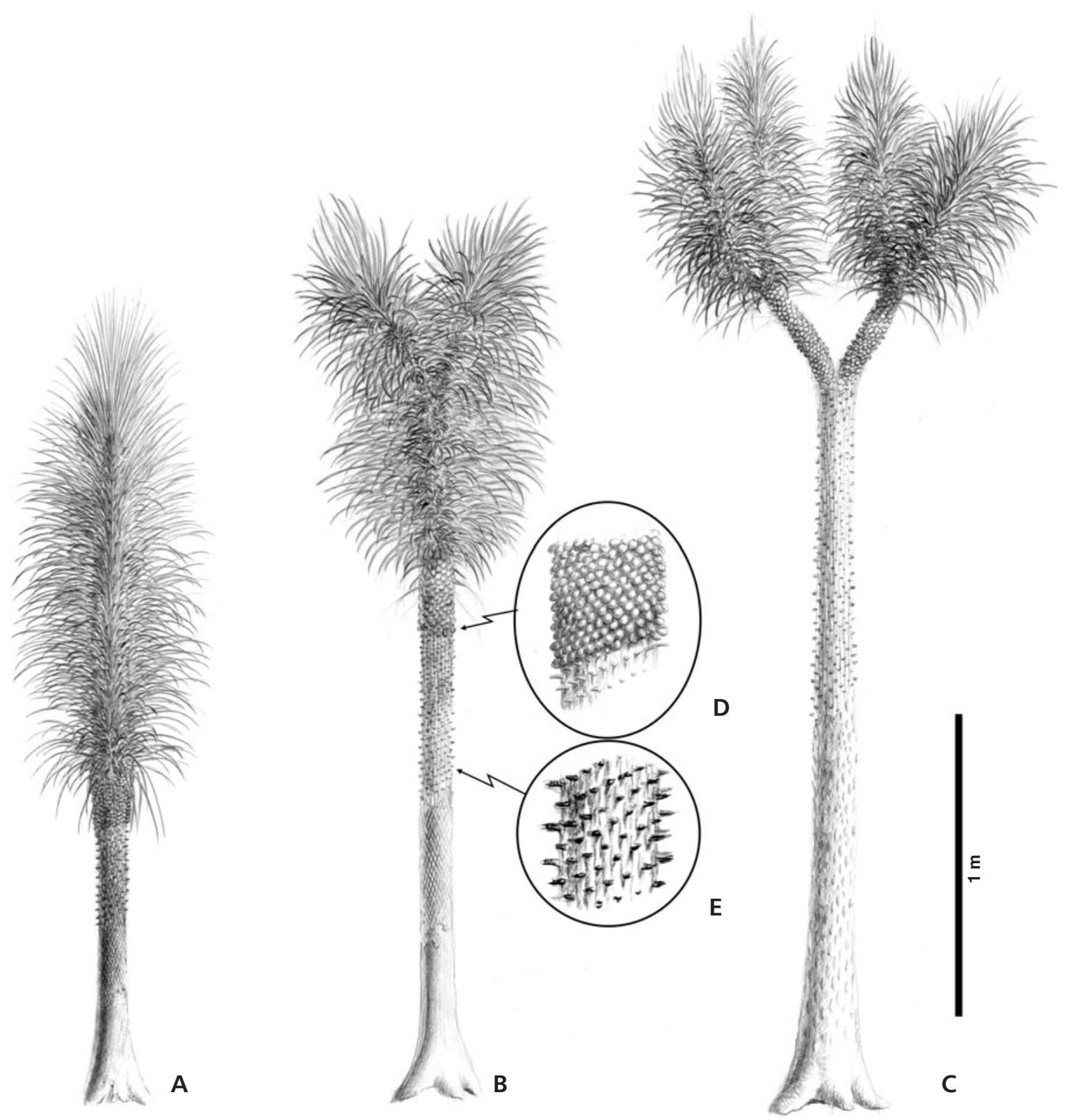

Figure 3. Hypothetical reconstructions of various growing stages of Omphalophloios feistmantelii (O. Feistmantel) comb. nov. emend. • A - young stage before the plant started branching. The columnar stem already bears fully matured sporangia, some of them being already shed leaving a naked axis of the "Puertollania" stage of the preservation. • B - plant in a later stage of its development after first branching with well developed "Puertollania" zone left after it shed sporangia. It is assumed that remnants of the uppermost bark of the vegetative part of the axis are still present. $\bullet \mathrm{C}-$ last stage of plant life cycle. Lower part of the stem is already decorticated (Knorria), the upper part shows pedicels without sporangia (Puertollania), sporangia are still present on the branches. $\bullet$ D - detail of Puertollania-stage of the preservation. $-\mathrm{E}$ - detail of axis-bearing sporangia without sporophyll laminae. Drawn by J. Svoboda.

features except the size that could justify keeping both species as separate.

Microspores were recovered by dissolving microsporangia in nitric acid for 24-48 hours and $\mathrm{KOH}$ for 1-2 hours. Most microspores were mounted in glycerine jelly for direct microscopic examination using a Nikon BX51 microscope. Some microspores were sputter-coated with gold for examination with a Cameca SX100 scanning elec- tron microscope (SEM). Descriptive terms for the spores follow the latest edition of the Glossary of Pollen and Spore Terminology (Punt et al. 2007). Spores are classified according to the system of dispersed spores suggested by Potonié \& Kremp (1954, 1955), Dettmann (1963), Smith \& Butterworth (1967) and Dybová-Jachowicz et al. (1977). In situ spores were compared directly with the original diagnoses (type specimens), descriptions and illustrations 


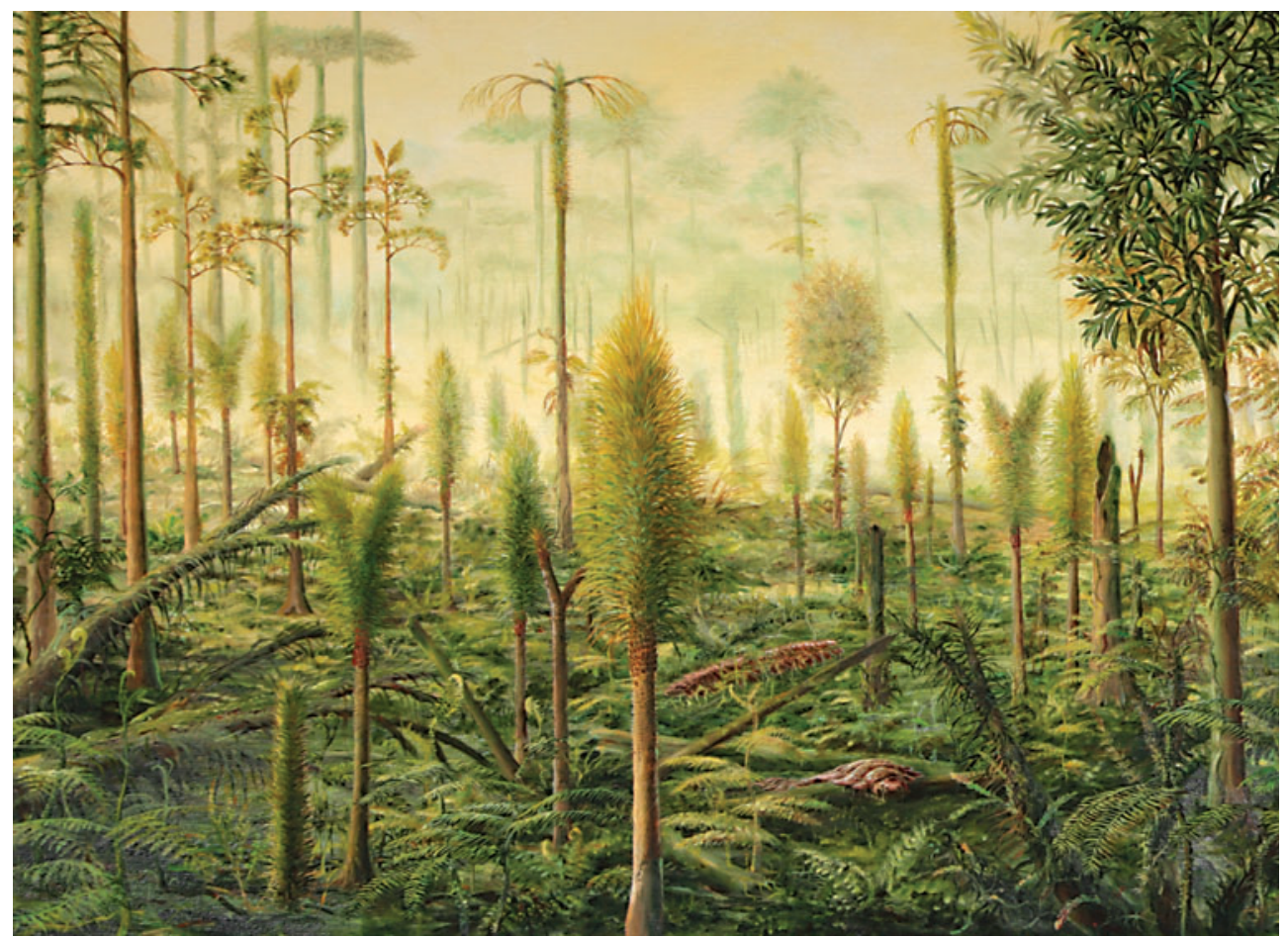

Figure 4. Reconstruction of part of the Upper Radnice Coal peat swamp colonized by $\mathrm{Om}$ phalophloios (O. Feistmantel) comb. nov. emend., with columnar plants with long leaves in the foreground. Behind is a lepidodendrid forest. Painted by J. Svoboda.

of dispersed spore species. Species determinations are based only on the original diagnoses, and not on the interpretations of subsequent authors.

Megaspores were recovered by dissolving small portions of cones (separated from the fertile specimens with mounted needle) in nitric acid for 12-24 hours and $\mathrm{KOH}$ for 1-2 hours. Some dry megaspores were examined in reflected light, some of these were sputter-coated with gold for examination with a CAMECA SX 100 SEM. Some transparent megaspores or their fragments were mounted in glycerine jelly for direct microscopic examination in trasmitted light. Two specimens (ZŠ537 from Puertollano, Emma Mine, Stephanian B-C, coal seam III and E390) were studied for comparison of Omphalophloios megaspores from the Czech Republic and Spain, and two specimens of O. cyclostigma (USNM 606556) and Omphalophloios sp. from the Pennsylvanian of the USA.

Cuticle structures of sporangia were studied on the set specimens for statistical confirmation of their structures. Specimens F775, F7475-9, F7480-1, F7483-5, F7487-8, F7490-2, F16317, F7486 and F7473 stored in the
Palaeontological Department of the West Bohemian Museum, Pilsen (Czech Republic), were macerated for sporangia and cuticles.

All specimens, except for F775, are preserved in the Velká opuka tonstein and come from the Kladno-Rakovník Basin. Specimen F775 comes from the Kladno Formation and is preserved on dark grey-colour claystone.

Sporangia were isolated with the aid of 35 per cent hydrofluoric acid for 24 hours. Selected sporangia and cuticles were directly examined using a JEOL JSM-6380LV SEM after the first step of the maceration. Other sporangia were macerated in nitric acid (65 per cent) for 16-20 hours depending on the degree of coalification, and subsequently washed in distilled water. Some sporangia were macerated in Schulze's solution for 20-45 minutes. Sporangia were examined under the SEM after the maceration in $\mathrm{HNO}_{3}$ and Schulze's solution. The remaining material was treated with 10 per cent potassium hydroxide for 1-2 hours to remove oxidation products and washed in distilled water again. Subsequently, sporangia with cuticles were observed under a Nikon BX51 phase contrast of biological microscope.

Figure 5. Omphalophloios feistmantelii (O. Feistmantel) comb. nov. emend. - A - fusiforme leaf cushions of vegetative part of the stem of Omphalophloios feistmantelii (O. Feistmantel) comb. nov. emend. showing the leaf scar preserved in the Velká opuka tonstein. František Mine in Otvovice. Kladno-Rakovník Basin. NM E6512; scale bar $10 \mathrm{~mm}$. $\bullet \mathrm{B}$ - detail of A; scale bar $5 \mathrm{~mm}$. $\bullet \mathrm{C}$ - thin rim of coalified outer cortical tissues of stem of Omphalophloios feistmantelii (O. Feistmantel) comb. nov. emend., preserved in the Z-tuff. Internal part (endocortical cast) is filled by sandstone with volcaniclastic admixture. Presence of outer cortex suggests it was tough and resisted decay much longer than other regions inside. Lubná, Kladno-Rakovník Basin. NM E2317; scale bar $10 \mathrm{~mm}$. $\bullet \mathrm{D}$ - leaf cushions of the vegetative stem of the specimen preserved in the Velká opuka tonstein. František Mine in Otvovice, Kladno-Rakovník Basin. NM E6513; scale bar $10 \mathrm{~mm}$. $\bullet$ E - fertile axis showing various stages related to an uneven split of 

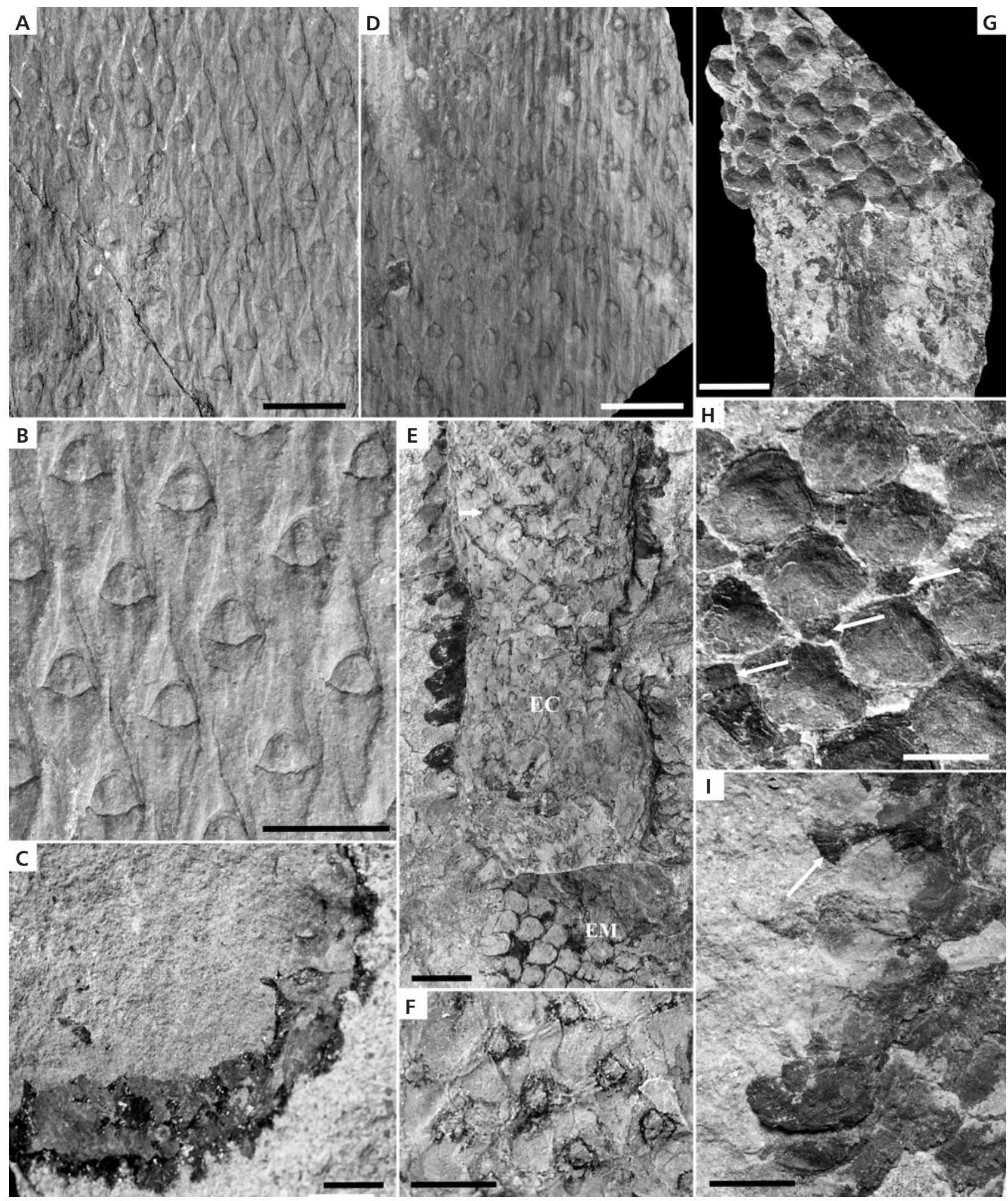

the matrix. Laterally attached are sporangia without sporophyll laminae. EC - endocortical cast showing the position of pedicels (arrow as an example) and imprints of sporangia on the cast surface. EM - external mold showing the original surface of the stem with imprints of the distal ends of sporangia into the tuff matrix. Tuchlovice, Kladno-Rakovník Basin. WBM F03721; scale bar $10 \mathrm{~mm}$. F - detail of E showing external mold; scale bar $5 \mathrm{~mm}$. - $\mathrm{G}$ - compression of fertile axis with sporangia with exposed internal cortical tissues beneath. Tuchlovice, Kladno-Rakovník Basin. WBM F03721; scale bar $10 \mathrm{~mm}$. $\bullet \mathrm{H}$ - detail of $\mathrm{G}$ showing sporangia. Arrows point to the distal parts of pedicels; scale bar $5 \mathrm{~mm}$. $\bullet \mathrm{I}$ - detail of G. Note laterally flattened sporangia along the margin of the stem. Arrows points to the pedicel; scale bar $5 \mathrm{~mm}$. 
SEM preparations, slides and digital photos from specimens are stored on the Palaeontology Department of the West Bohemian Museum, Pilsen, Czech Republic.

\section{Systematic section}

Class Lycopsida Scott, 1909

Order Isoetales Bartl, 1830

Family Sporangiostrobaceae Wagner, 1983

\section{Genus Omphalophloios White, 1898}

\section{Omphalophloios feistmantelii (O. Feistmantel) comb. nov. emend.}

Lectotype. - The specimen E974 (Fig. 17A, B) was selected as the lectotype. This specimen bears both megasporangia and microsporangia.

1875-1876 Sigillariaestrobus Cordai O. Feistmantel; O. Feistmantel, p. 254, pl. 60, figs 3, 4 .

1875-1876 Sigillariaestrobus Feistmanteli O. Feistmantel; O. Feistmantel, pp. 255-256, pl. 60, figs 1, 2.

1931 Sporangiostrobus Feistmanteli (O. Feistmantel) Němejc; Němejc, pp. 1-13, figs 1-7, pl. 1.

1995 Sporangiostrobus feistmantelii (O. Feistmantel) Němejc; Bek \& Straková, pp. 37-51, pls 1-8.

For more complete synonymy, see Bek \& Straková (1995).

Emended diagnosis. - Vegetative stem columnar with rhomboidal, flat, symmetrical to slightly asymmetrical leaf cushions without keel and parichnos markings. Leaf scars sub-triangular to bell-shaped, located about in middle of leaf cushions. Microsporangia smooth, circular to oval, helically arranged, densely spaced on columnar or dichotomously branched fertile axes/apices. Megasporangia and microsporangia alternating in irregular patches. Laminae grass-like, midrib prominent. Pedicels narrow, straight. Circular to oval trilete cingulate microspores. Sculpture of proximal and distal surface microspinate, microverrucate, microgranulate, spinate, granulate, verrucate or with foveolae. Laevigate inner body about half the radius. Large trilete coronate megaspores. Amb circular to subtriangular. Subequatorial corona approximately a half the megaspore radius, consisting of several layers of appendages. Laesurae very high, narrow, sinuous extending to the inner margin of corona. Contact faces ornamented by tubercles or spines. Distal surface covered by more or less densely spaced cylindric to clavate appendages.

Description. - Three forms of the preservation have been recognized: (1) compressions (mostly fertile parts of the stem); (2) impressions of vegetative and fertile axis; (3) endocortical casts and their impressions. The origins of these forms of preservation are explained in detail by Rex \& Chaloner (1983) and Chaloner (1999). The preservation of endocortical casts indicates that the outer cortex was much more tough and resistant to decay than the internal tissues, which resulted in a hollow stem filled with sediment. This type of the preservation is typical for specimens fossilised in mudstones, which underwent decompositional processes for a longer period of time compared to specimens buried instantly in volcanic ash.

\section{Vegetative axes}

Only two specimens (E6512-3, NM) of the vegetative axis of Omphalophloios feistmantelii were identified, comprising only about $3 \%$ of all the specimens. They represent small fragments preserved as impressions of helically arranged symmetrical to slightly asymmetrical rhomboidal leaf cushions with gently rounded lateral angles (Fig. 5A, $\mathrm{B}, \mathrm{D})$. Upper and lower margins of the cushions are slightly inflected in opposite directions. Leaf cushions are flat, smooth, without keel and parichnos markings and separated by thin lines that appear as ridges in impressions. The leaf cushions on specimen E6512 are about 16 to $18 \mathrm{~mm}$ long and 4 to $5.5 \mathrm{~mm}$ wide. The differences in width are partly related to flattening of the specimen along the lateral margin; the larger width is closer to original shape of leaf cushions. They reach their maximum width about the middle of the length of leaf cushion, where the subtriangular to slightly bell-shaped leaf scars are located. The leaf scars are 2.6 to $3 \mathrm{~mm}$ in height and 3.4-3.6 mm wide. No clear leaf vascular bundle markings were observed in the leaf scar.

It is not possible to estimate the diameter and the length of the vegetative axis of $O$. feistmantelii because neither of the specimens possesses their original lateral margins. They were, however, more than $60 \mathrm{~mm}$ wide and $120 \mathrm{~mm}$ long. The specimen E2317, preserved in the Z-tuff bed, contains a fragment of a nearly uncompressed stem buried by volcanic ash in an upright position and associated with remains of a fertile axis on the bedding surface. The stem diameter is about $88 \mathrm{~mm}$. The inner part of the stem is completely filled by tuff surrounded by about a $1 \mathrm{~mm}$ thick and locally undulating vitrain ring (Fig. 5C). Its decorticated outer surface displays very prominent vertical ribs. Due to its preservation in upright position, it has to represent the near-basal part of the stem, $<400 \mathrm{~mm}$ above the base, which is the thickness of the Z-tuff bed.

Leaves of the vegetative axis are absent on both specimens and we can only speculate that they were grass-like, single-veined and several tens of centimeters long like those of the similar species $O$. puertollanense. 


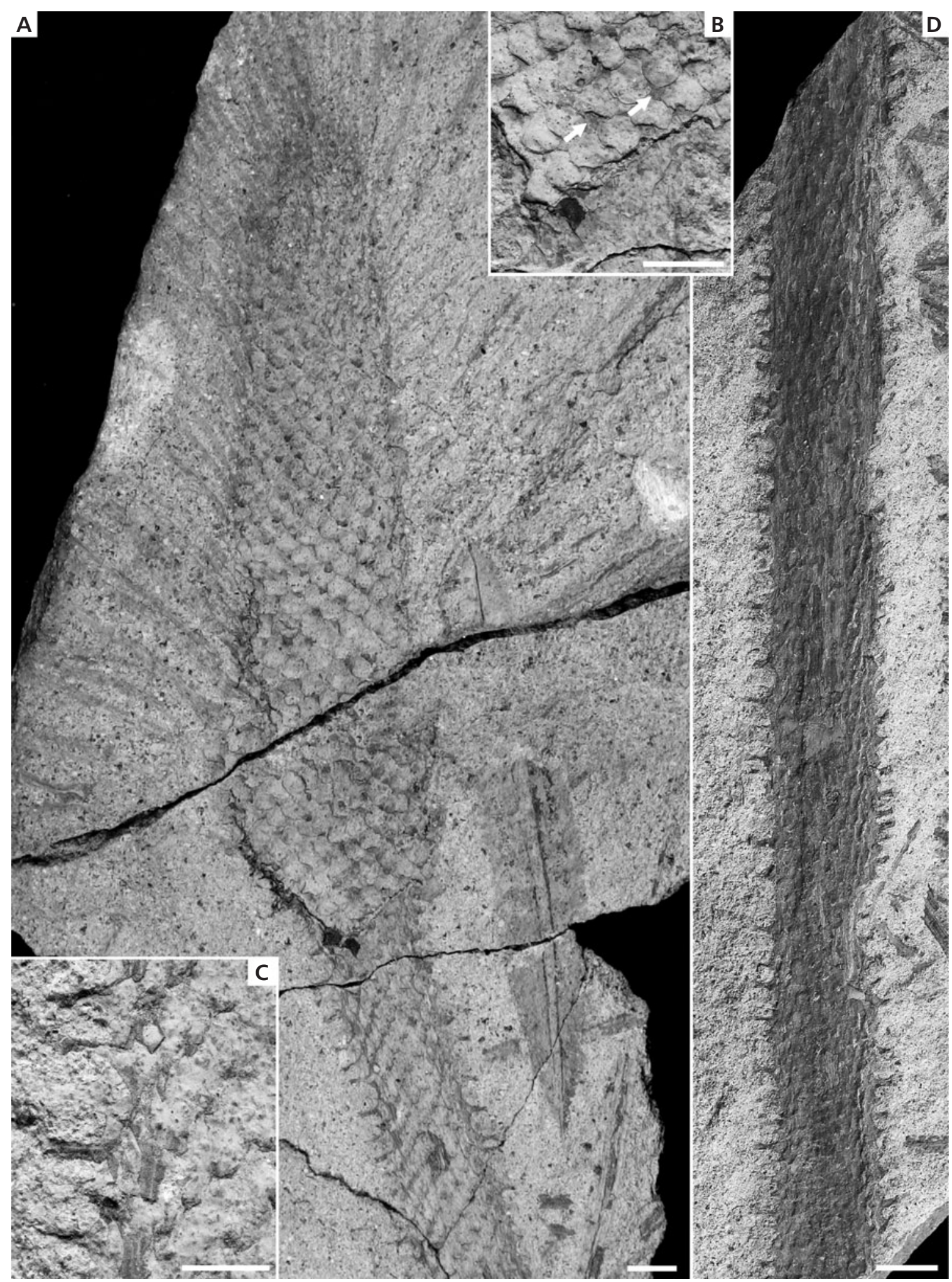

Figure 6. Omphalophloios feistmantelii (O. Feistmantel) comb. nov. emend. • A - fertile apex showing different stages of maturation; zone with complete sporophylls passes downward into axes with shed sporophyll laminae and consequently into the zone with shed sporangia where only pedicels left (Puertollania-stage of preservation). Z-tuff, Lubná, Kladno-Rakovník Basin. NM E5625b; scale bar $10 \mathrm{~mm} \cdot \bullet$ B - details of A. Notice the transition zone between the Puertollania-stage of maturity and zones bearing sporophyll laminae-less sporangia; scale bar $5 \mathrm{~mm}$. $\bullet \mathrm{C}$ - detail of A showing pedicel on "Puertollania"; scale bar $10 \mathrm{~mm}$. $・ \mathrm{D}$ - axis with pedicels left after shedding of the sporangia (Puertollania-stage of preservation) preserved as external mold. Z-tuff, Filip opencast Mine, Lubná, Kladno-Rakovník Basin. NM E3675; scale bar 10 mm. 


\section{Fertile axis}

Four different stages of the preservation of fertile axes related to disarticulation were recognized among the studied specimens: (1) axis with sporangia and laminae (complete sporophylls); (2) axes with sporangia but without laminae; (3) axes with pedicels lacking laminae and sporangia (laminae and sporangia were shed); (4) axes without outer cortical tissues. Stage 1 preservation is most common, comprising about $75 \%$ of all specimens.

The lengths and widths of fertile axes are variable with the complete length of a fertile axis with attached sporangia (stages 1 and 2) preserved only in specimen E5625b, which is $157 \mathrm{~mm}$ long of with about $20 \mathrm{~mm}$ at the base seeming to lack laminae (Fig. 6). In contrast, some fragments of fertile axes lacking both ends are over $250 \mathrm{~mm}$ long with complete sporophylls, thus showing Stage 1 preservation (Fig. 12A). The lengths of fertile axes without laminae (Stage 2) varies. That of the specimen E5625b is about $20 \mathrm{~mm}$ whereas the specimens E2202 and E6362 represent 158 and $123 \mathrm{~mm}$ long laminae-less axes respectively. If laminae are preserved, they are visible only along the edges. However, the preservation of laminae of some specimens is poor and it is not always clear whether they were present at the time of burial. Laminae-less fertile axes with sporangia still attached were observed on specimens preserved in mudstones. However, some specimens preserved in volcaniclastics with sporangia also seem to lack laminae. Although most of the fragments of fertile axes are cylindrical, some specimens show more or less pronounced tapering (Figs 10, 12A). The width of the fertile axes varies from 16 to $115 \mathrm{~mm}$ and the distribution of their diameters indicates clustering into discontinuous size classes: $65-50 \mathrm{~mm}, 40-30 \mathrm{~mm}$ and 25 to $18 \mathrm{~mm}$ (Fig. 2A). Axes wider than $70 \mathrm{~mm}$ are very rare.

Three specimens display V-shaped isotomously dichotomizing fertile axis (Figs 9A, 14A, 16A). The subsequent axes always reach about two-thirds of the thickness of parent axis. The divergent angles vary between $35^{\circ}, 45^{\circ}$ and $60^{\circ}$. The largest bifurcating axis is about $90 \mathrm{~mm}$ wide whereas the width of smallest one is only $30 \mathrm{~mm}$.

Stage 3 preservation is represented by disarticulated fertile axes without sporangia and laminae but covered with the proximal part of sporophylls, i.e. pedicels. Such preservation corresponds to Remy \& Remy's (1975) lycopsid genus Puertollania. These disarticulated axes were found in connection with preservation of the Stage 2 and/or 1 type (Fig. 6A). On this specimen the naked pedicel-bearing axis is about $80 \mathrm{~mm}$ long and 15 to $17 \mathrm{~mm}$ wide. However, the largest Puertollania specimen (E3675) is about $245 \mathrm{~mm}$ long and 16-17 mm wide fragment of a straight cylindrical axis, broken at both ends (Fig. 6D). Pedicels are arranged into a helix ascending at an angle of about $40^{\circ}$. Neighbouring pedicels in the helix are 3-3.5 mm apart. In proximal view the bases of pedicels can be surrounded by shallow imprints of circular sporangia (Figs 5E, F, H, I, 6C). The pedicels are about 4-5 mm long and $0.8 \mathrm{~mm}$ wide, except at the base and distal end where their width increases to about 2 and $1.3 \mathrm{~mm}$ respectively (Fig. 6). In cross section pedicels are probably subtriangular as indicated by the imprints of their proximal ends through the sporangia (Figs 11, 16A).

The Stage 4 represents decorticated Knorria-like preservation of axes without outer cortical tissues showing only discontinuous vertical and gently raised ridges about 2 to $3 \mathrm{~mm}$ apart (Fig. 22). These decorticated axes are usually preserved as mold-casts (Fig. 5G) and some of them dichotomize (Fig. 22). Their Knorria-type surface is separated from the outer surface of previous Stage 3 preservation only by about a $1 \mathrm{~mm}$ thick coalified tissue layer.

Endocortical-casts preservation is typical for some specimens preserved in mudstones. These casts are usually flat-oval in outline and show more or less imperfect versions of the leaf bases as narrow raised areas to squarrose-rhomboidal cushions with closed to slightly open ends (Fig. 21). Some of them bear sporophyll scars (Fig. 21B-D), while others are preserved as a combination of endocortical cast and external mold (Fig. 21F-H).

\section{Sporangia and sporophylls}

Sporangia of Omphalophloios feistmantelii are more or less circular to slightly oval disc-like bodies if observed as compressions from frontal view. In lateral view along the axis margins they are, oval, inserted at an angle of $30-50^{\circ}$, measured between the abaxial side of the long axis of the sporangium and the stem (Figs 5E, 10A, 11, 20A, B). This oval shape and position are considered to be nearer to the original shape of the sporangia and their angle of insertion. They are 7-8 $\mathrm{mm}$ long and 5-6 $\mathrm{mm}$ wide; their length/breath ratio varies between 1.40 and 1.45 . Sporangia are arranged

Figure 7. Omphalophloios feistmantelii (O. Feistmantel) comb. nov. emend., Z-tuff, Lubná, Kladno-Rakovník Basin, NM E5625a. • A-E - tetrads of microspores of the Densosporites cf. spinifer-type. These microspores were macerated from apical sporangia. All $\times 500$. $\bullet \mathrm{F}-$ microspore of the Densosporites annulatus-type; $\times 500 . \cdot \mathrm{G}-$ microspore of the Cristatisporites saarensis-type; $\times 500$. $\bullet \mathrm{H}-$ microspore of the Densosporites sphaerotriangularis-type. All these microspores were macerated from sporangia in the middle portion of the specimen; $\times 500$. $\bullet \mathrm{I}-$ part of sporangium showing mass of microspores and their distal surfaces. This sporangium was taken from apical part; SEM; scale bar $20 \mu \mathrm{m}$. $\bullet \mathbf{J}-$ tetrad of microspores of the Densosporites-type, isolated from apical sporangium; SEM; scale bar $10 \mu \mathrm{m} . \cdot \mathrm{K}-$ microspores of the Densosporites spinifer-type; $\times 500$. 

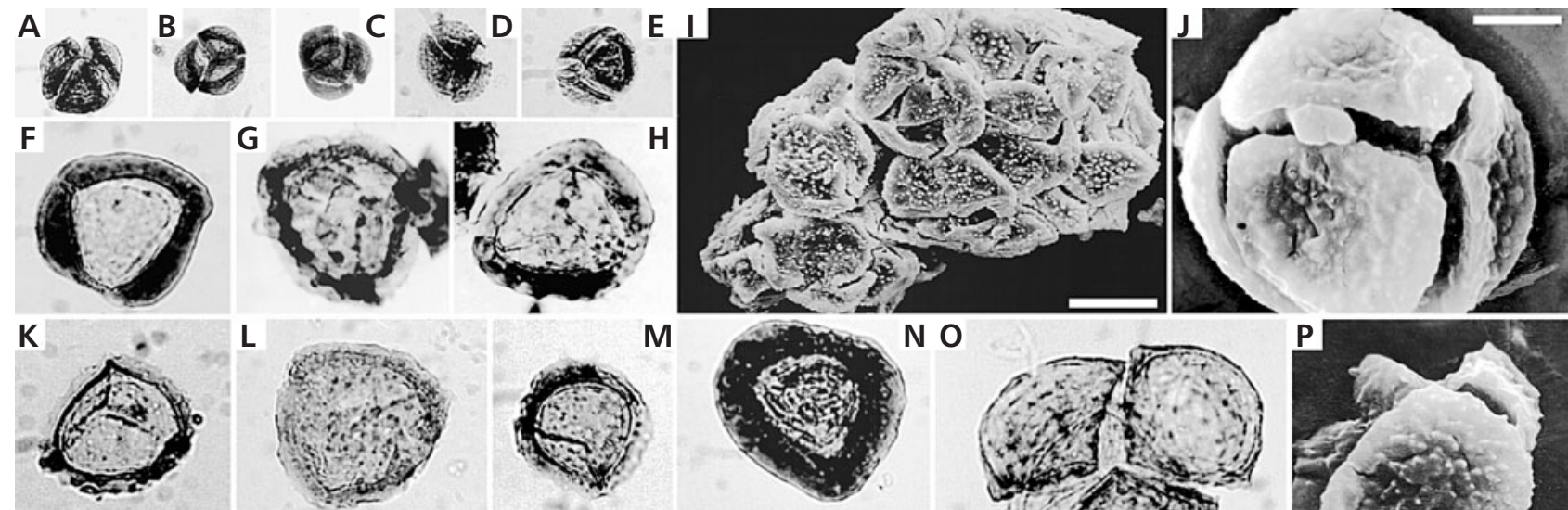

M
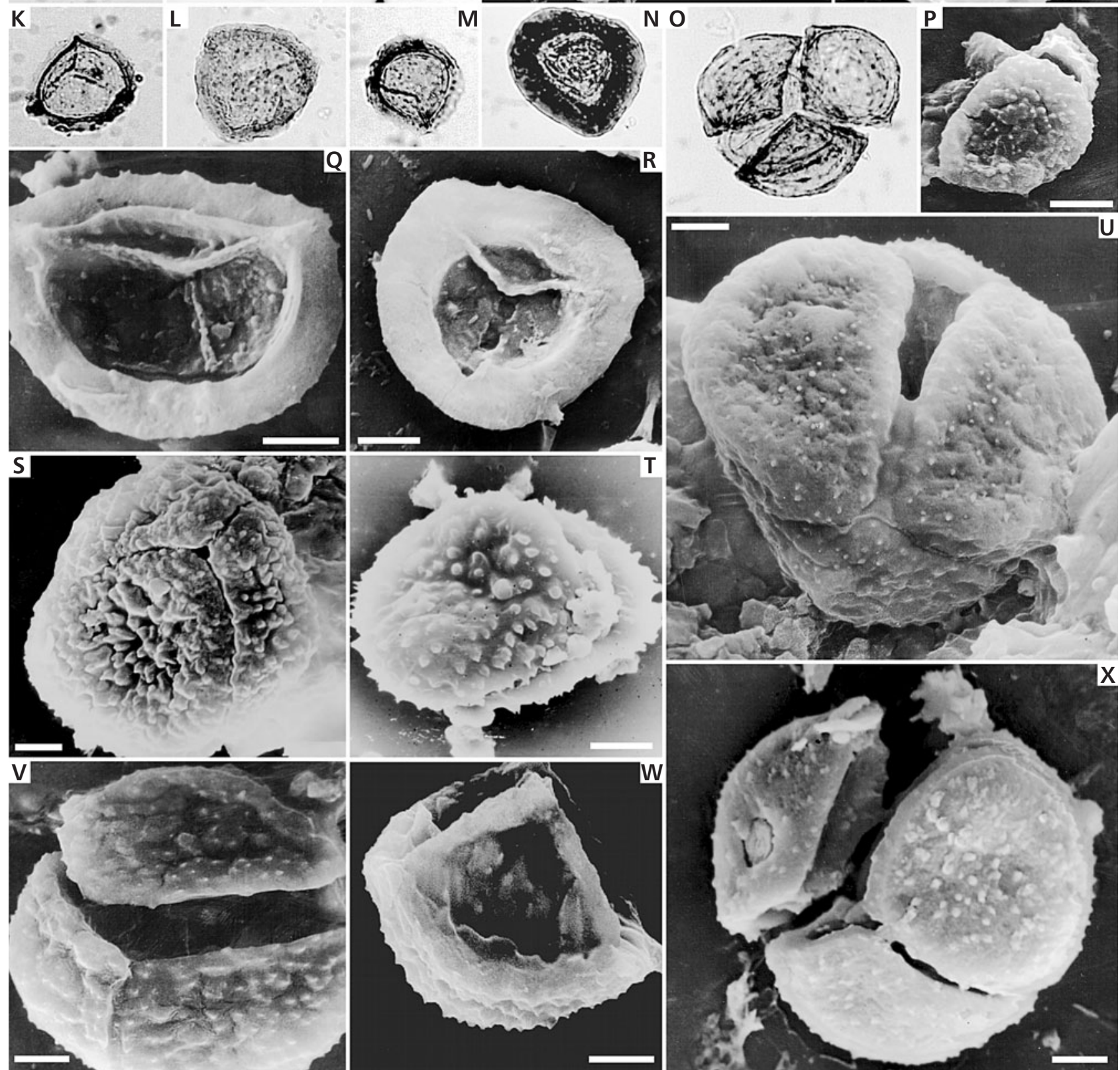

$-\mathrm{L}$ - microspore of the Densosporites granulosus-type; $\times 500 . \bullet \mathrm{M}-$ microspores of the Densosporites spinifer-type $\times 500$. $\bullet \mathrm{N}-$ microspore of the Densosporites lobatus-type. These microspores were macerated from sporangia in the middle portion of the specimen; $\times 500$. $\bullet \mathrm{O}-$ tetrad of microspores of the Densosporites spinifer-type; $\times 500 . \bullet \mathrm{P}$ - distal surface of microspore of the Densosporites-type, isolated from apical sporangium; SEM; scale bar $20 \mu \mathrm{m} . \cdot \mathrm{Q}$ - proximal surface of microspore of the Densosporites sphaerotriangularis-type. Notice labrum, finely microgranulate sculpture of central body and almost laevigate cingulum; SEM; scale bar $10 \mu \mathrm{m}$. $\bullet \mathrm{R}$ - proximal surface of microspore of the Densosporites pseudoannulatus-type. Notice the labrum and laevigate sculpture of central body and cingulum; SEM; scale bar $10 \mu \mathrm{m} . \bullet \mathrm{S}-\mathrm{V}, \mathrm{X}$ - tetrad of microspores of the Densosporites-type showing its distal sculpture. Notice the difference in sculpture elements; all SEM. All scale bars $10 \mu \mathrm{m}$. $-\mathrm{W}$ - lateral view of microspores of the Densosporites-type. Note the different sculpture of proximal (upper) and distal (lower) surfaces; SEM; scale bar $10 \mu \mathrm{m}$. 
in a helix ascending at an angle that varies between $35^{\circ}$ and $42^{\circ}$. They are densely packed and neighbouring sporangia are imbricated when preserved as compression (e.g., Figs 8E, F, 11, 16A, 24A). The zone of overlap can be up to $2 \mathrm{~mm}$ wide. The diameter of compacted sporangia in frontal view varies between 4.1 and $7.3 \mathrm{~mm}$. This variation is not related to whether they are mega- or microsporangiate. The distribution of megasporangia and microsporangia is very irregular. Megasporangia with visible impressions of megaspores can be easily distinguished from microsporangia with the naked eye ( $c f$. Figs $8 \mathrm{E}, \mathrm{F}, 11,17 \mathrm{~A}, \mathrm{~B}, 26 \mathrm{~A}$ ), which allows the distribution patterns of megasporangia and microsporangia to be seen. Some fragments are completely microsporangiate (e.g., E973, Fig. 16A; E5626, Fig. 10A), whereas others are megasporangiate (E6935, E6937; Fig. 9C, E) or mixed (IGP 2014/001, Fig. 10B; E2247, Fig. 14A).

Sporangia are smooth, except for the overprinted outline of the pedicels below or the megaspores within (e.g. Figs 11C, 17A). The sporangial surfaces display a polygonal cell pattern (Fig. 8G-J), described in detail below.

The attachment of the sporangium to the pedicel is not clearly seen. In some specimens, sporangia can be observed to be separated by pedicels if preserved along lateral margins of the stem. In these instances, the pedicels fill the space between the sporangia and seem to be attached adaxially along the whole sporangium length. The adaxial position of the sporangia on the pedicel was observed by Leisman (1970) on Sporangiostrobus (i.e. Omphalophloios) kansanensis Leisman. Sporophyll laminae are incomplete in all the specimens; the longest preserved laminae (specimens E982 and Z S̆ 480) observed are up to 160 and $180 \mathrm{~mm}$ long respectively. The laminae are narrow, grass-like with entire margins, about $2 \mathrm{~mm}$ wide with a prominent midrib (Fig. 9B, F). About 25-30 mm above the base they start to broaden and 3-4 mm above it they reach their maximum width of 6-6.5 mm (Figs 9C, D, 12A, B). However, their base itself is constricted to about $2 \mathrm{~mm}$, matching the width of pedicel at the point of attachment. Laminae were probably shed when sporangia ripened leaving a narrow zone along the fertile axis with only sporangia (Fig. 6A).

\section{Microsporangia}

All microsporangia from studied specimens were compressed from a variety of directions, so it is not possible to reconstruct the original exact shape. Nevertheless, microsporangia appear as disc-like (Figs 31F, 32C) or club-like in shape (Figs 31F, 32B) being 4-7 mm in diameter. The microsporangial wall is apparently two cell-layers thick (Figs 31G, 32E) and is around $30 \mu \mathrm{m}$ thick (Figs 32D/K, 31H/C).

The outer sporangial layer (Fig. 32E, arrow O), represented by epidermal cells, is impressed into a thick cuticle. The cellular details of the microsporangial outer layer can be clearly seen from the inner side of the cuticle, (Figs $32 \mathrm{H} / \mathrm{X}_{1} ; 31 \mathrm{G}$ ) whereas only poorly preserved cells are visible from the outer side of the cuticle (Fig. 32H/ $\mathrm{X}_{2}$ ). The thickness of the outer layer sensu stricto appears very thin but cannot be exactly specified because it is not well preserved (Fig. 32K). The cuticle of the outer layer displays conspicuous and well-preserved cells consisting of two types. The first type $\left(\mathrm{C}_{2}\right)$ occupies the dehiscence area (Figs $\left.33 \mathrm{~A} / \mathrm{C}_{2} ; 31 \mathrm{D}\right)$ and the second type $\left(\mathrm{C}_{1}\right)$ occupies the remaining area of other surface of the sporangium (Fig. 33A/C $_{1}$ ). The $\mathrm{C}_{1}$ type cells are random (the shape of cells is very variable), slightly elongate, 24(37)67 $\mu \mathrm{m}$ long and 10(16) $26 \mu \mathrm{m}$ wide (Figs 33B, C, 35B). Anticlinal walls are straight or rounded.

Interesting objects are located in the $\mathrm{C}_{1}$ area. The are individual cell, filled by very small honeycomb-like structures (?secretory cells) (Fig. 33F). These cells are $30 \mu \mathrm{m}$ long and $20 \mu \mathrm{m}$ wide and irregularly spread on the sporangium and could represent glandular cells with internal secretory structures.

Figure 8. Omphalophloios feistmantelii (O. Feistmantel) comb. nov. emend. • A, D - circular object full of microspores of the Densosporites-type macerated from microsporangium; Břasy, Radnice Basin. NM E5625a; scale bars $50 \mu \mathrm{m}$. • B, C - details of circular objects full of microspores of the Densosporites-type macerated from microsporangium; Břasy, Radnice Basin, NM 5625a; scale bars $100 \mu \mathrm{m}$. $\bullet \mathrm{E}-$ fragment of microsporangiate part of the fertile axis preserved in claystone. Třemošná, Pilsen Basin, NM d56/2004; scale bar $10 \mathrm{~mm}$. $• \mathrm{~F}$ - detail of E showing microsporangia; scale bar 3 mm. - $\mathrm{G}, \mathrm{H}$ - adaxial view of part of the sporangium with preserved epidermal cell pattern; SEM, low vacuum; scale bar $200 \mu \mathrm{m}(\mathrm{G})$ and $500 \mu \mathrm{m}$ (H). - I - adaxial view of sporangium; SEM, low vacuum; scale bar $1 \mathrm{~mm}$. $\bullet \mathrm{J}$ - abaxial view of sporangium; SEM, low vacuum; scale bar $1 \mathrm{~mm}$.

Figure 9. Omphalophloios feistmantelii (O. Feistmantel) comb. nov. emend. • A - dichotomizing fertile apex with attached distal laminae preserved in a tonstein in the Upper Radnice Coal. Radnice Basin. NM E982. Coll. by K. Feistmantel; scale bar 10 mm. • B - fragment of a fertile axis with sporophylls bearing adaxial sporangia. Arrows points to the pedicel and laterally extended laminae base. Velká opuka tonstein. Tuchlovice Mine in Tuchlovice, Kladno-Rakovník Basin. NM E2324; scale bar $10 \mathrm{~mm}$. $\bullet$ C - fertile axis fragment showing outer surface with megasporangia and laterally extended bases of sporophyll laminae. Velká opuka tonstein, Kladno, Kladno-Rakovník Basin. NM E6935; scale bar 10 mm. • D - thin fertile axis with distal laminae attached. Velká opuka tonstein, Tuchlovice Mine, Kladno-Rakovník Basin. CGS ZŠ 395; scale bar 10 mm. • E - fragment of fertile apex with distal laminae. NM E6937; scale bar 10 mm. • F - fertile apex. Velká opuka tonstein, Schoeller Mine, Kladno, Kladno-Rakovník Basin. NM E2329; scale bar 10 mm. 
A
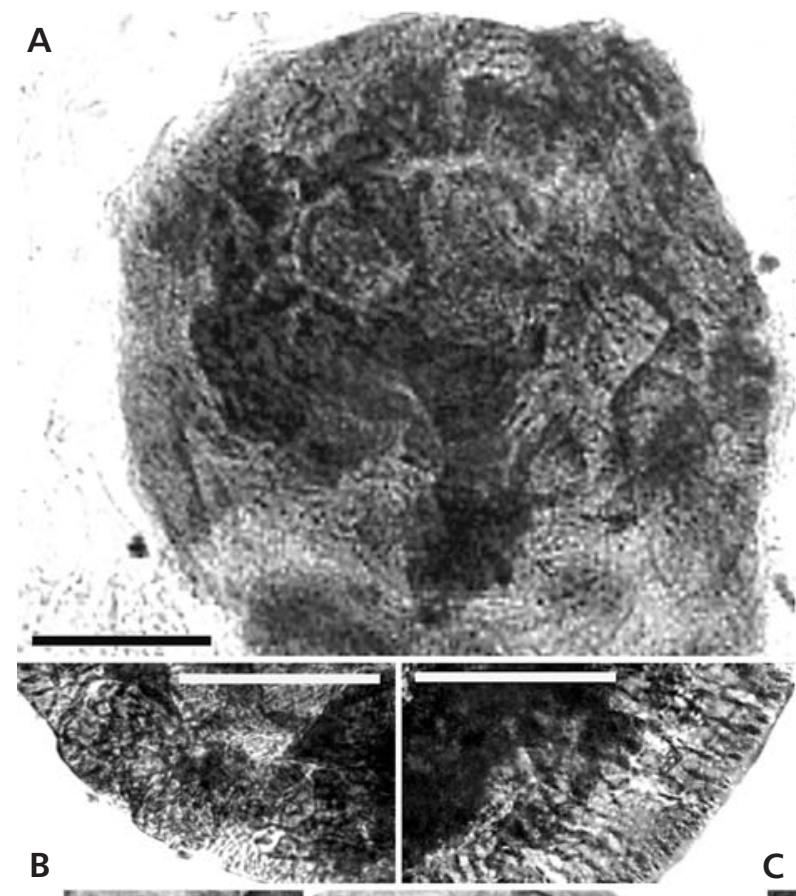
3. Q7.

19.6.
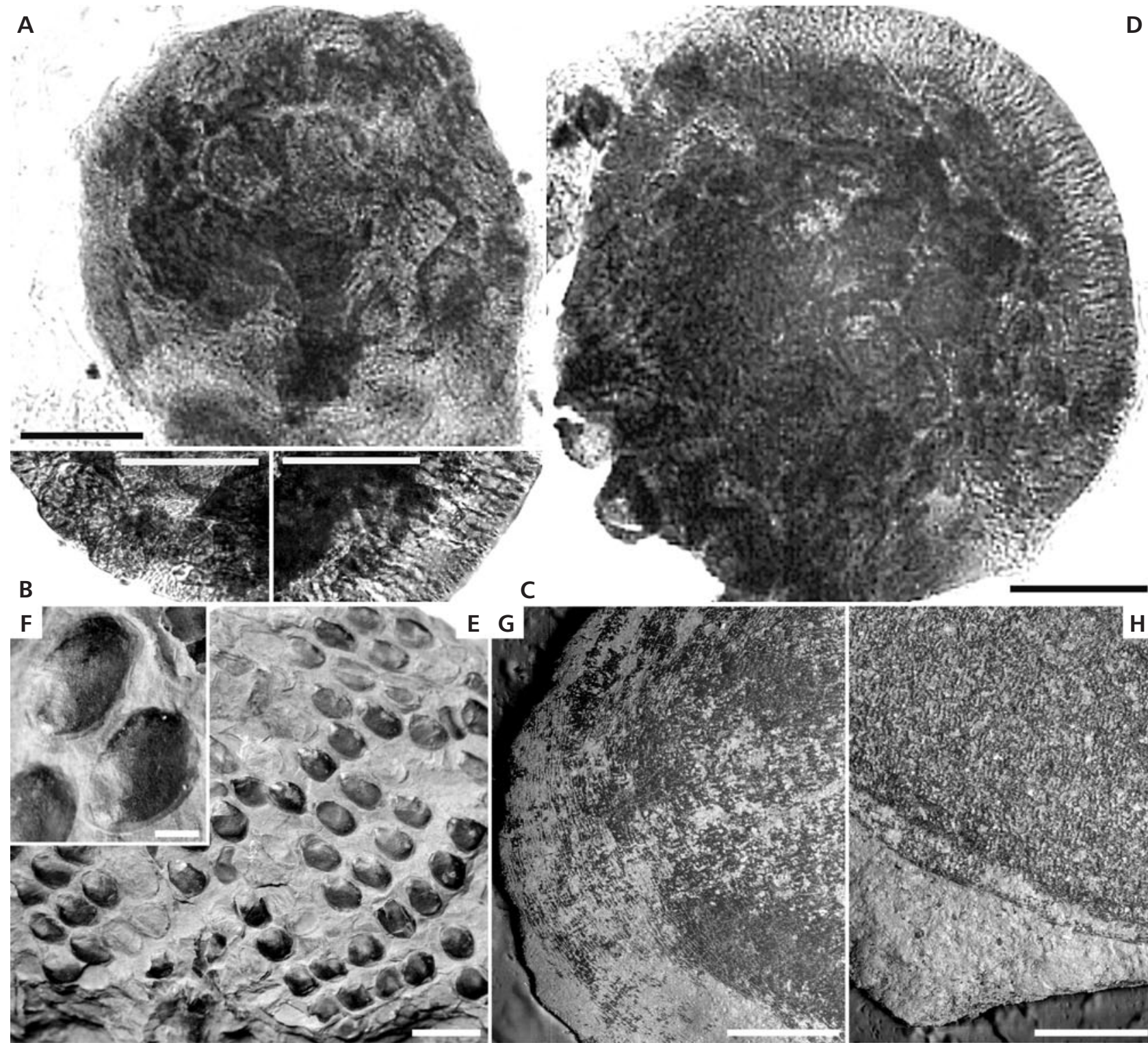
5 of
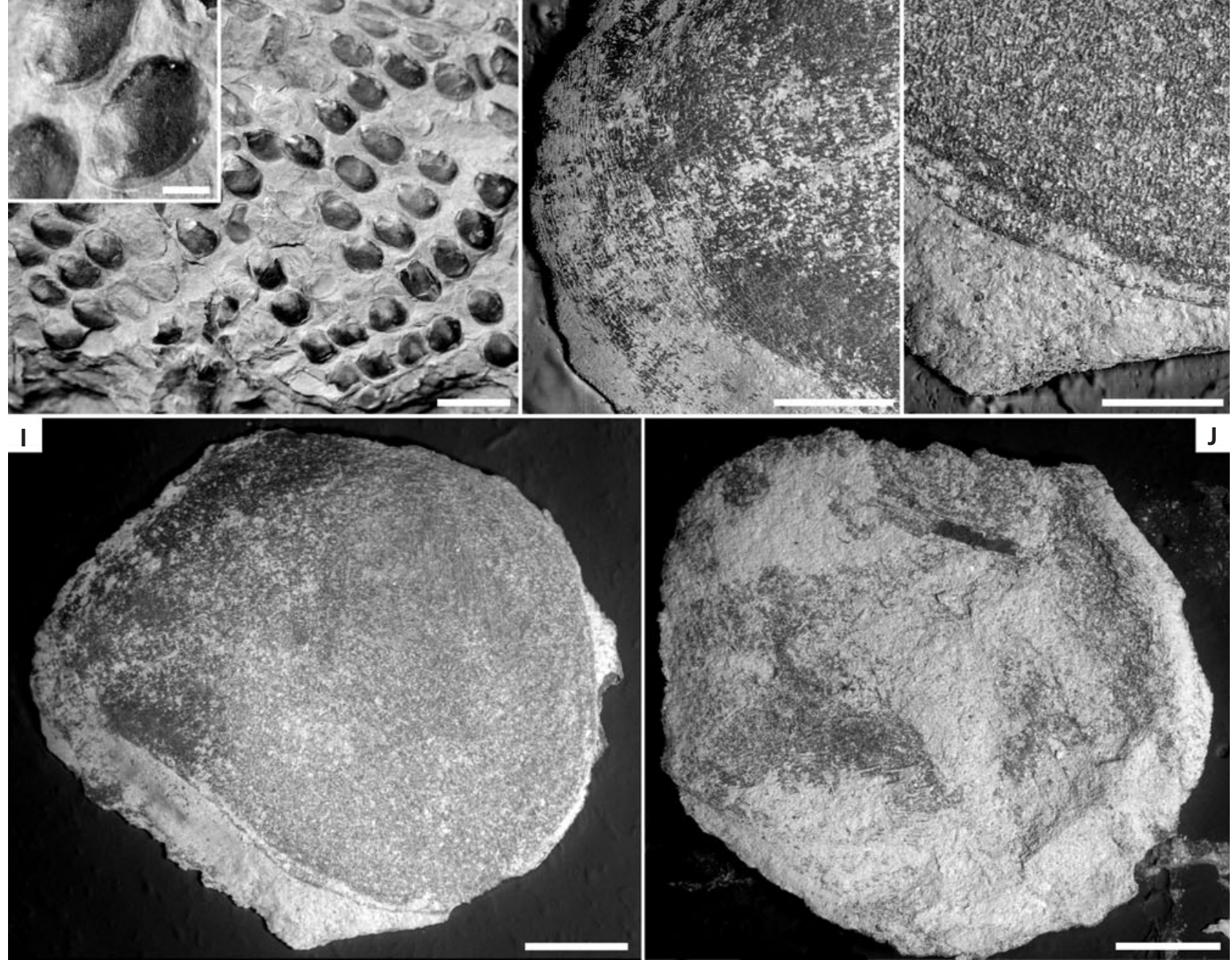


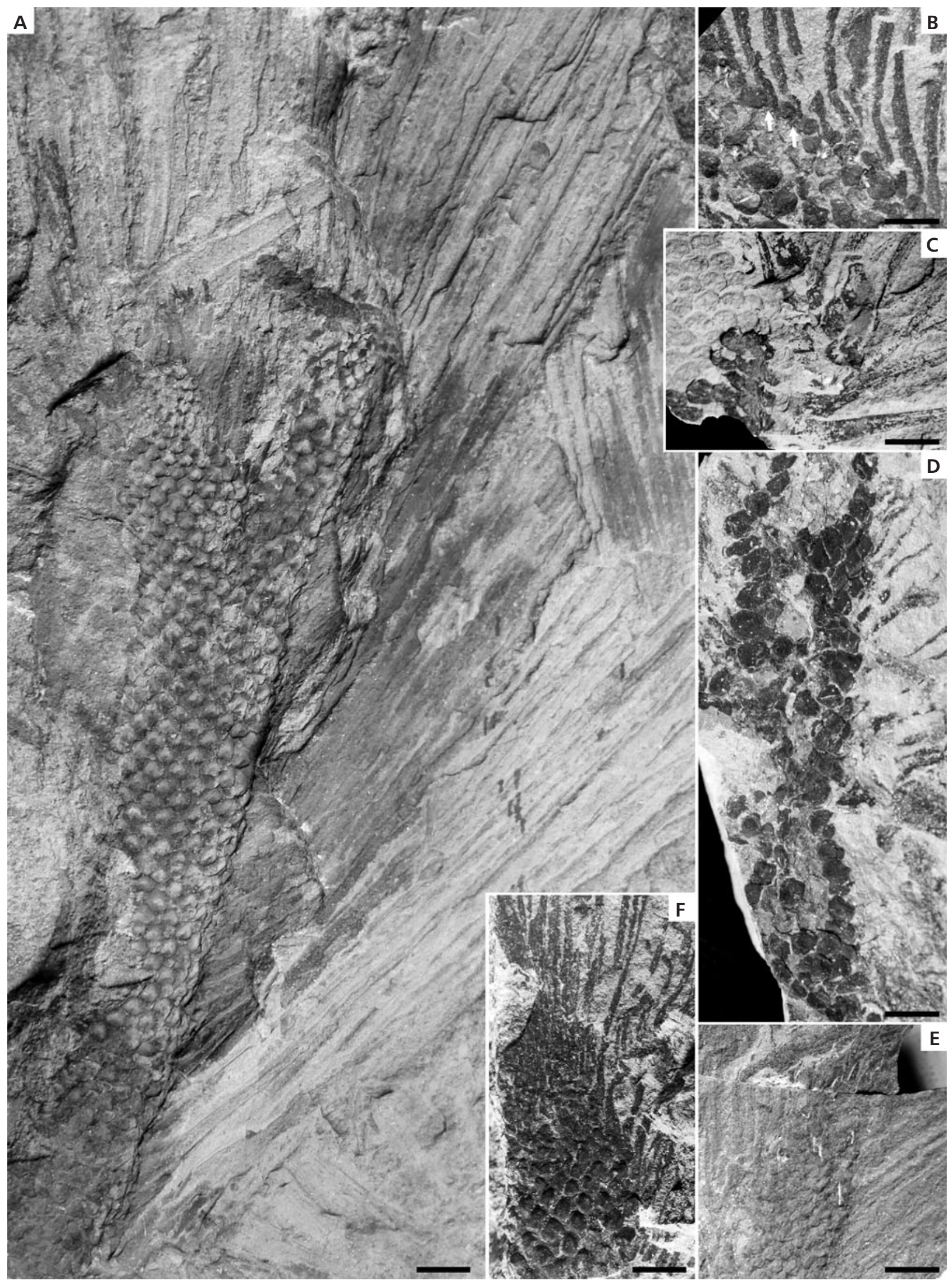




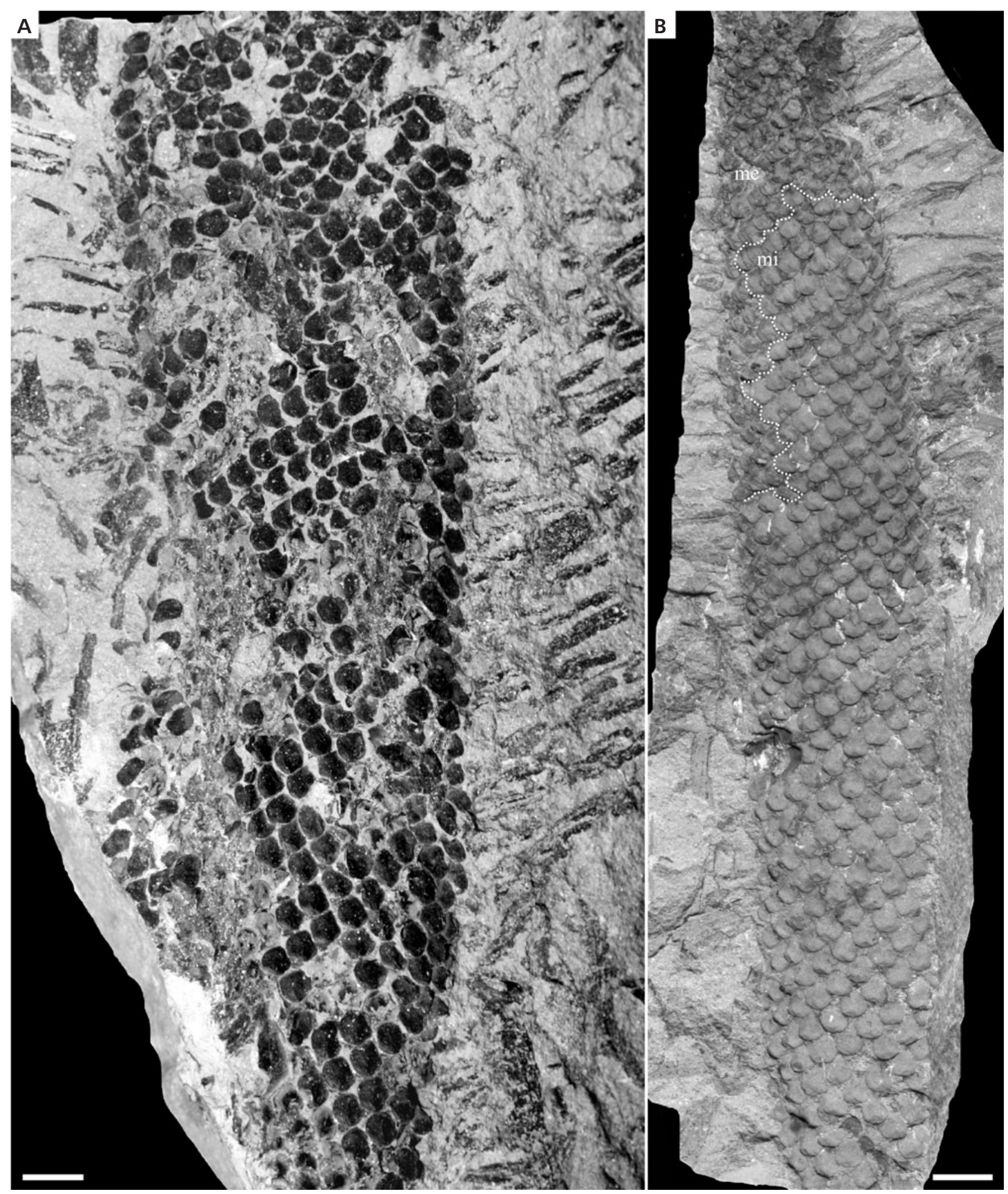

Figure 10. Omphalophloios feistmantelii (O. Feistmantel) comb. nov. emend. $\bullet A-$ microsporangiate part of fertile axis with attached distal laminae. Velká opuka tonstein. Tuchlovice Mine, Kladno-Rakovník Basin. NM E5626; scale bar $10 \mathrm{~mm}$ • B - gradually tapering dominantly microsporangiate part (mi) of fertile axis. Upper part of the specimen is mainly megasporangiate (me). Note the irregular boundary between mega- and microsporangiate part of the axis. Velká opuka tonstein. Ronna Mine, Kladno, Kladno-Rakovník Basin. FS IGP2014/001; scale bar 10 mm. 


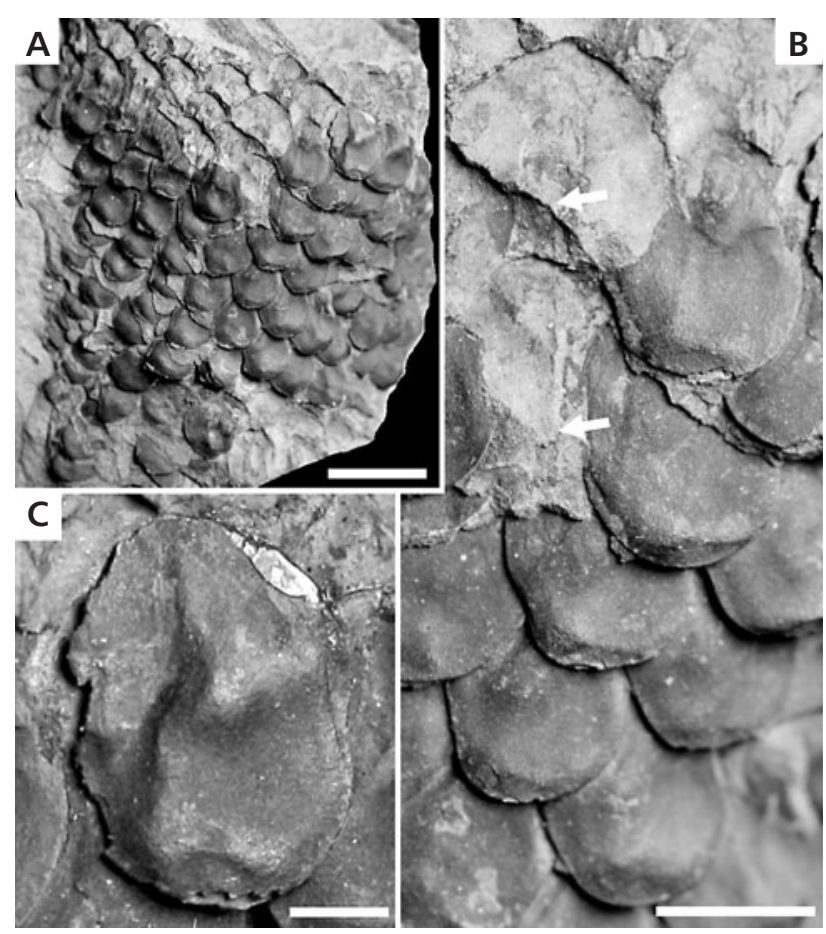

Figure 11. Omphalophloios feistmantelii (O. Feistmantel) comb. nov. emend. Břasy, Radnice Basin. NM E6931. • A - fragment of microsporangiate part of a fertile axis preserved in mudstone (Mydlák) from the roof of the Upper Radnice Coal. One of the original Corda's specimens redescribed and first figured by O. Feistmantel (1875-1976) in plate LX, fig. 1 as Sigillariaestrobus Feistmanteli O. Feistmantel; scale bar $10 \mathrm{~mm}$. - B - detail of A showing flattened and imbricated sporangia. Arrows points to pedicels imprinted into the matrix beneath the sporangium; scale bar $5 \mathrm{~mm}$. $\S \mathrm{C}$ - detail of A. Note the microsporangium with outline of pedicel overprinted from beneath the sporangium; scale bar $2 \mathrm{~mm}$.

Trichomatous papillae (Fig. 33G, I arrow) and thickened-wall cells (Fig. 33J) occur close to the dehiscence area. They are 8-20 $\mu \mathrm{m}$ long, needle-like in shape with an extended base (Fig. 33G).

A thickened elliptical rim inside some cells is an interesting structure that could be interpreted as a water pore, probably a laminar passive hydathode (Fig. $33 \mathrm{H}$ ). Such cells are $42 \mu \mathrm{m}$ long and $10 \mu \mathrm{m}$ wide.
The $\mathrm{C}_{2}$ type cells are randon, elongate, 21(33)55 $\mu \mathrm{m}$ long and 4(7)10 $\mu \mathrm{m}$ wide (Figs 32A area d, 33D, E) and create degenerated dehiscence area. These cells are generally narrower than $\mathrm{C}_{1}$ type of cells. Anticlinal walls are straight or rounded. The dehiscence area contains strips that probably represent cuticle above the sclerenchymatously thickened cells (Figs 33D, E, 35A dark areas). These strips are 100-250 $\mu \mathrm{m}$ long and 10-15 $\mu \mathrm{m}$ wide and consist of cells of the $\mathrm{C}_{2}$ type (Fig. 33E). The sclerenchymatous thickened cells probably enable the dehiscence of sporangia. Specimen F775 (Fig. 31B) shows the outer surface of the sporangium with granulations (Figs $32 \mathrm{G}$ arrow, F). The granulation occurs in the dehiscence area (Fig. 32F). It is not clear if the granulation represents the sclerenchymatously thickened cells or a type of trichomes or papillae. Clearly identifiable stomatal apparatuses were not observed. The dehiscence band is located in the equatorial area of the sporangium and is around $0.5 \mathrm{~mm}$ broad. The dehiscence band broadest is in the distal part of the sporangium and narrows toward to the base (Fig. 32A-C/d area).

The inner sporangial layer is not well preserved. Fig. 32K (arrow) shows palisade-like cells that are around $30 \mu \mathrm{m}$ long. This layer is observed only after maceration in HF. The layer dissolves after maceration in Schulze's solution because it is parenchymatous, a cell-type that is not resistant to Schulze's solution.

Rarely, in some parts of microsporangia, it is possible to observe a very thin layer (Fig. 32E arrow, I), which closely overlaps the microspores. This layer has reticulate (Fig. 32E arrow, I), fibrillose or slightly globous character and could be interpreted as the remains of tapetum. It consists of sporonin and is resistant to maceration.

\section{Megasporangia}

As in the microsporangia, all megasporangia were compressed and therefore, their exact original shape could not be reconstructed. Megasporangia are 5-7 $\mathrm{mm}$ in diameter

Figure 12. Omphalophloios feistmantelii (O. Feistmantel) comb. nov. emend. Velká opuka tonstein, Tuchlovice Mine, Kladno-Rakovník Basin. CGS $\mathrm{ZS}$ 474. $\bullet$ A - large fragment of fertile axis; scale bar $20 \mathrm{~mm}$. B - detail of A. Notice laterally extended base of distal laminae; scale bar $10 \mathrm{~mm}$. $\bullet \mathrm{C}-$ proximal surface of microspore of the Densosporites-type. Note sculptured proximal contact area, labrum and smooth proximal surface of cingulum; SEM; scale bar $20 \mu \mathrm{m}$. $・ \mathrm{D}$-distal surface of microspore of the Densosporites-type; SEM; scale bar $15 \mu \mathrm{m}$. $\bullet$ E-distal surface of microspore of the Densosporites-type. Note the different sculpture elements on specimens on D and E; SEM; scale bar $20 \mu \mathrm{m}$. $\bullet \mathrm{F}$ - detail of E showing the shape of sculpture elements; SEM; scale bar $5 \mu \mathrm{m}$.

Figure 13. Omphalophloios feistmantelii (O. Feistmantel) comb. nov. emend. Velká opuka tonstein, Tuchlovice Mine, Kladno-Rakovník Basin. CGS ZŠ 474. In situ megaspores of the Zonalesporites superbus-type. All SEM. • A - semilateral view showing elevated and flexuose rays of the trilete mark, contact area and distal surface (in the lower part). Almost the whole corona is destroyed; scale bar $500 \mu \mathrm{m}$. $\bullet \mathrm{B}$ - two transversally broken megaspores; scale bar $500 \mu \mathrm{m} . \bullet \mathrm{C}, \mathrm{F}, \mathrm{G}$ - distal view showing cylindrical to clavate projections, some of them growing together each other longitudinally (G) or in their terminal parts (C, F). The surface of the projections is coarse and sculptured. Note the terminal papillae; scale bars C, F $20 \mu \mathrm{m}$; G $10 \mu \mathrm{m}$. $\bullet$ D, E - detail of B of (specimen on the right). Cross-section of semilateral compressed megaspore extending in the distal part. Note of the solid projections in the cross-section and detail structure of exine (E); scale bar $20 \mu \mathrm{m}$. 


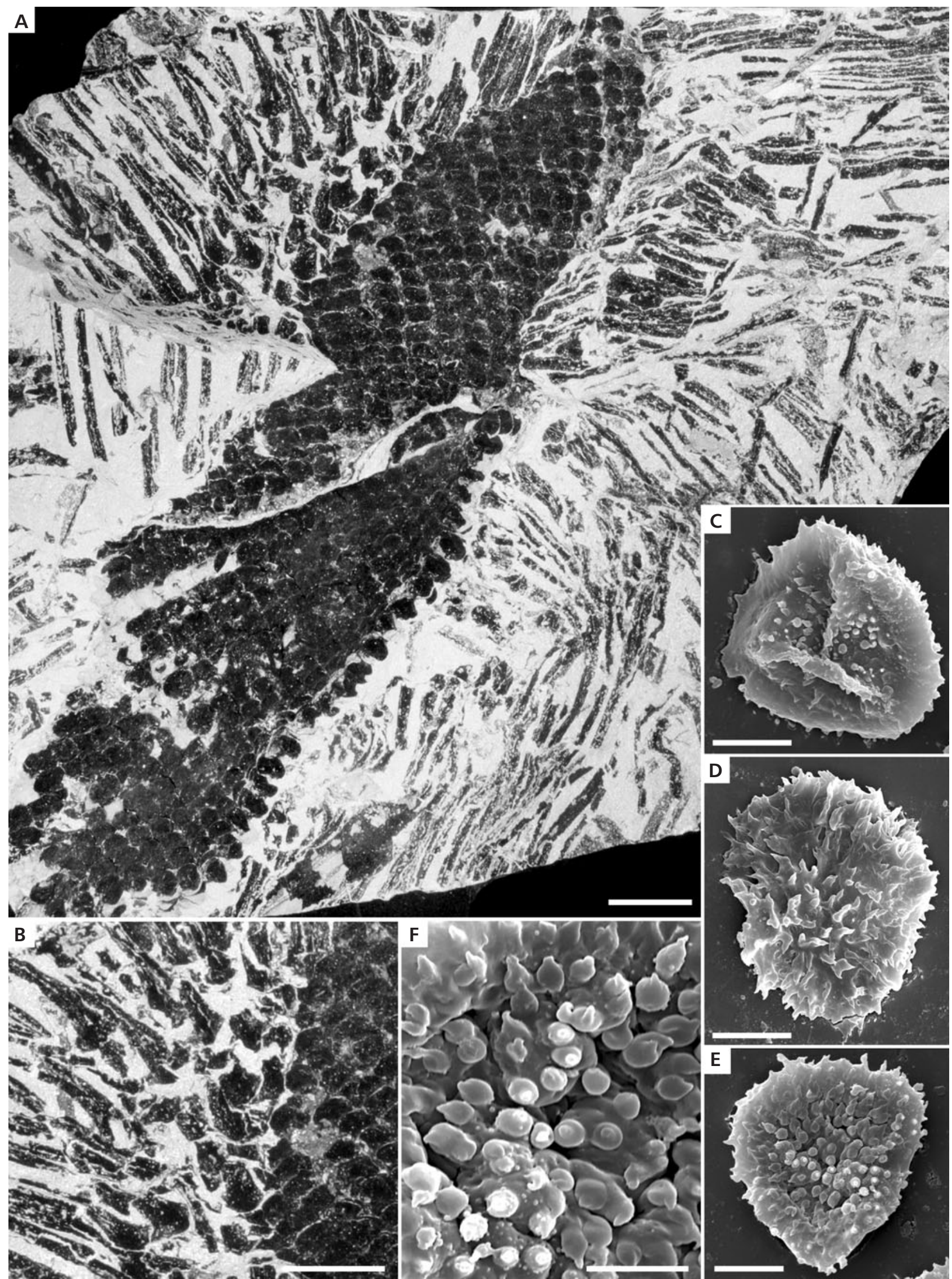




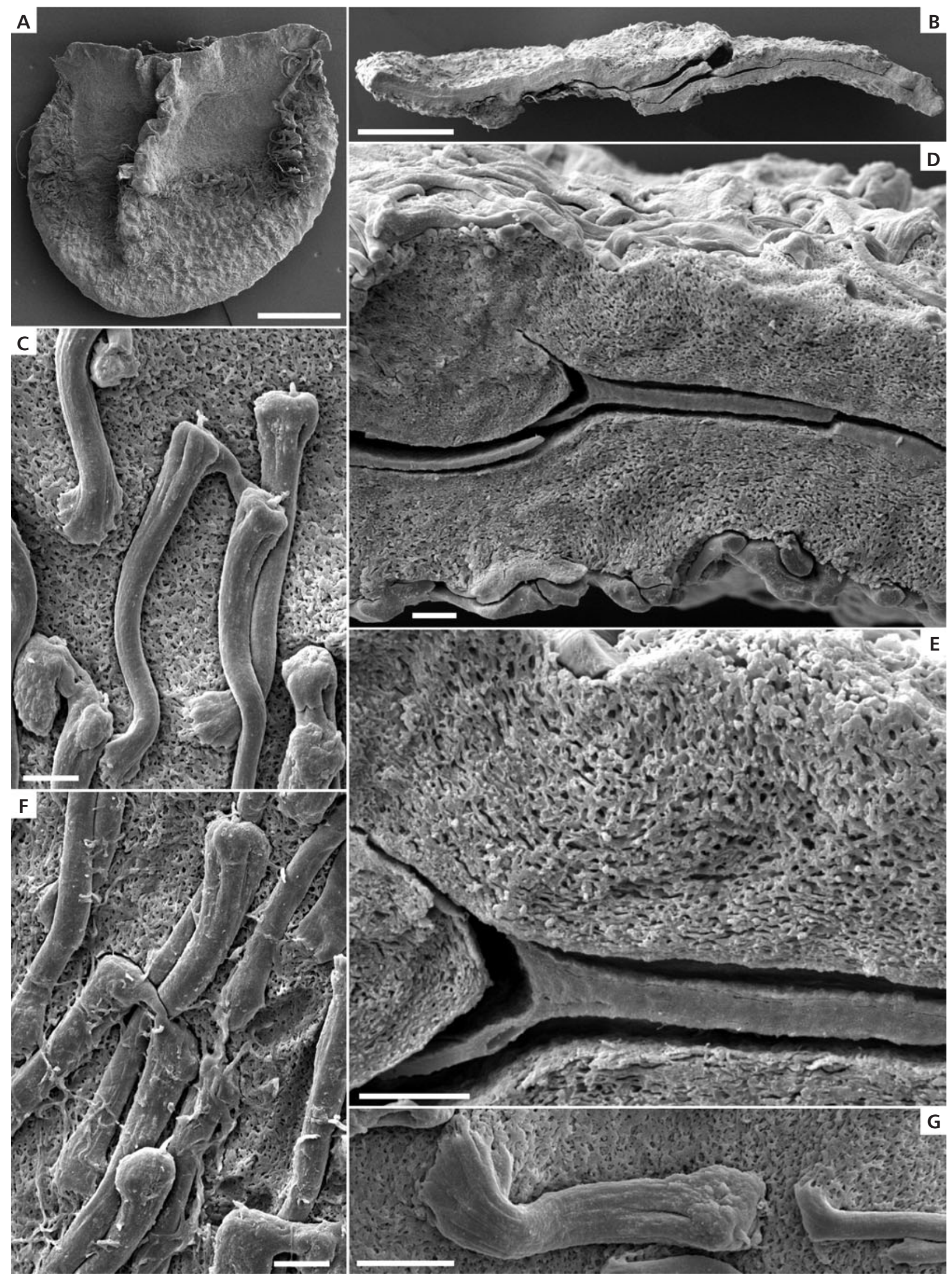



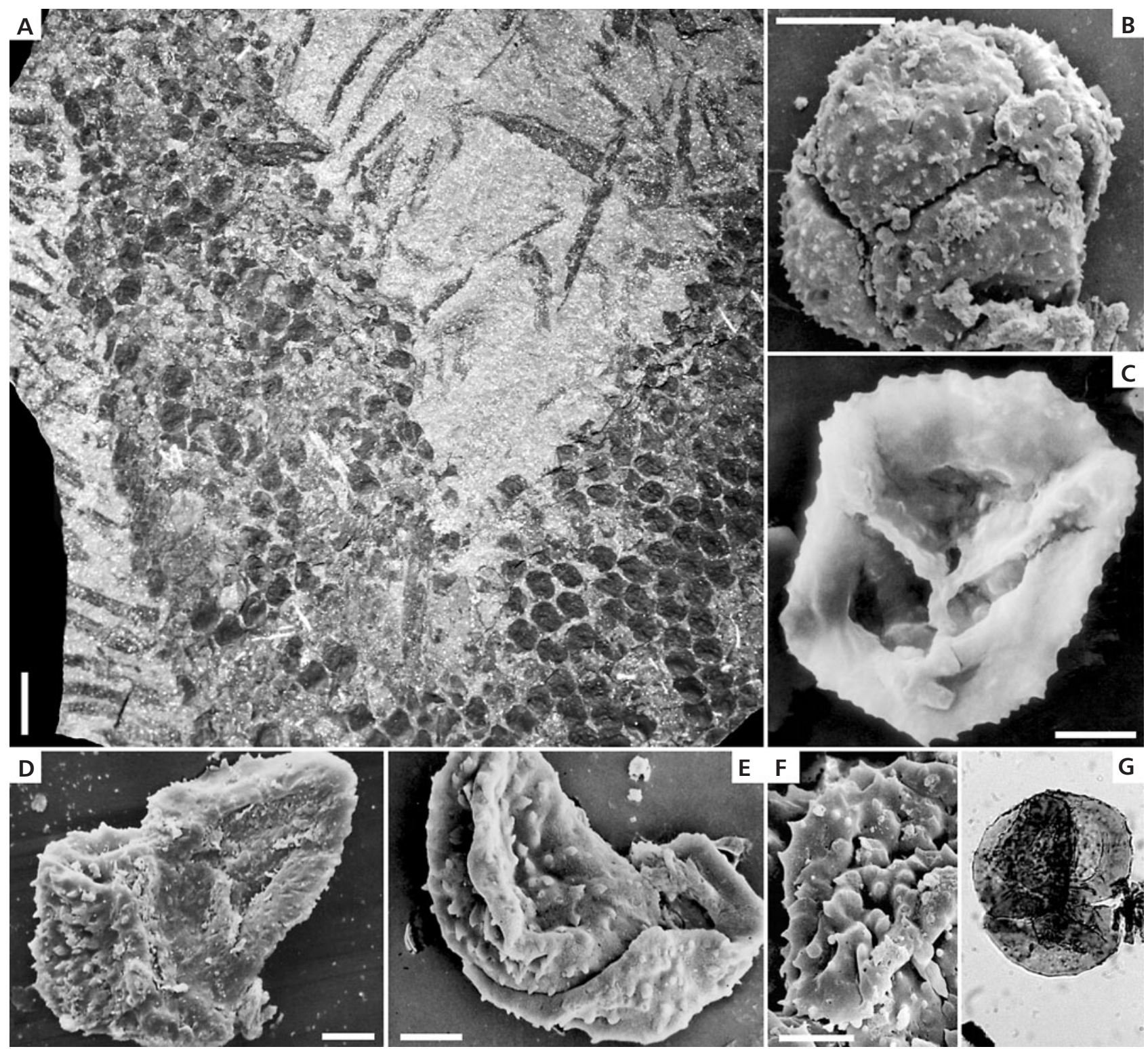

Figure 14. Omphalophloios feistmantelii (O. Feistmantel) comb. nov. emend. Velká opuka, Tuchlovice Mine, Kladno-Rakovník Basin. NM E2247. - A - dichotomizing fertile axis bearing still complete sporangia (both micro- and megasporangia) with distal laminae; scale bar $10 \mathrm{~mm}$. $\bullet$ B tetrad of microspores of the Densosporites-type; SEM; scale bar $25 \mu \mathrm{m}$. $\bullet \mathrm{C}$ - proximal surface of microspore of the Densosporites sphaerotriangularis-type; SEM; scale bar $10 \mu \mathrm{m}$. D - two microspores of the Densosporites-type. Note the difference between the sculpture of distal (left specimen) and proximal surfaces (right specimen); SEM; scale bar $10 \mu \mathrm{m}$. $\bullet \mathrm{E}$ - two specimens of microspores of the Densosporites-type; SEM; scale bar $10 \mu \mathrm{m}$. $\bullet \mathrm{F}$ - detail of distal surface of microspore of the Densosporites-type; SEM; scale bar $10 \mu \mathrm{m} . \bullet \mathrm{G}-$ tetrad of microspores of the Densosporites-type; $\times 500$.

(Fig. 32J). The megasporangial wall is around $10-20 \mu \mathrm{m}$ thick and like the microsporangial wall consisting of two one-cell thick (Figs 34B, 31A). Nevertheless, only fragments of the sporangial wall are preserved [Fig. 32I (from specimen Fig. 31E), J (arrow), L (arrow)] and frequently preservation is poor (Fig. 32L).

The cuticle of the outer layer displays conspicuous and well-preserved cells consisting of two types, as in the microsporangia. The first type $\left(\mathrm{C}_{2}\right)$ occupies the dehiscence area (Figs 32I (arrow), 34A, C, D/ $\mathrm{C}_{2}$ ) and the second type $\left(\mathrm{C}_{1}\right)$ occupies the remaining area of the sporangium outer surface (Fig. 34D/C 1 ).

The $\mathrm{C}_{1}$ type cells are randomly oriented, the cells are slightly elongate, $28(40) 72 \mu \mathrm{m}$ long and $12(18) 28 \mu \mathrm{m}$ wide (Fig. $34 \mathrm{D} / \mathrm{C}_{1}$ area). Anticlinal walls are straight or rounded. Cells filled by secretory structures, trichomatous papillae and laminar passive hydathodes were not observed on megasporangia, probably due to the fragmentary character of the sporangial wall.

The $\mathrm{C}_{2}$ type cells are random, and in shape are elongate, 
19(32)50 $\mu \mathrm{m}$ long and 5(8)11 $\mu \mathrm{m}$ wide [Fig. 34A, B (area d), D $\left(\right.$ area $\left.\mathrm{C}_{2}\right)$ ]. The dehiscence area, as in the microsporangia, contains strips that probably represent cuticle originally located above sclerenchymatously thickened cells (Fig. 34A, C, D). These strips are 100-250 $\mu \mathrm{m}$ long and 10-15 $\mu \mathrm{m}$ wide and consist of cells the same as the $\mathrm{C}_{2}$ type (Fig. 34C). The sclerenchymatously thickened cells probably aid the dehiscence of the sporangium. The dehiscence band is placed in the equatorial area of the sporangium and is around $0.4 \mathrm{~mm}$ broad.

\section{Microspores}

Trilete microspores are circular to subtriangular in shape and $28(53) 112 \mu \mathrm{m}$ in diameter. The cingulum reaches one-fifth to one-half of the radius. The distal surface (including cingulum) is laevigate, microgranulate, microspinate, microverrucate, granulate, verrucate, vermiculate, spinate, foveolate and conate (Figs 12D-F, 14B, D, F, 16B-E, $20 \mathrm{C}, \mathrm{H}, \mathrm{I})$. The proximal surface of the inner body is spinate, microspinate, verrucate, microverrucate, granulate, microgranulate, conate, laevigate (Figs $12 \mathrm{C}, 14 \mathrm{C}, 16 \mathrm{~F}$, 20D-G). The proximal surface of the cingulum is laevigate, spinate, microspinate, foveolate. The distal surface is more densely sculptured than the proximal surface. Rays of the trilete mark reaching to the end of the inner body. Sometimes the cingulum seems to be divided into lighter and darker zones, probably due to its irregular thickness. The inner body is laevigate, subtriangular to subcircular and possesses a trilete mark (Fig. 16F, G). All microspores belong to several species of the genera Densosporites and Cristatisporites (Figs 14B, E, G, 16G-L, 17C-F, 20J, K).

\section{Megaspores}

Trilete megaspores have a circular to subtriangular amb of the central body, 1330(1796)3024 $\mu \mathrm{m}$ in diameter (300 specimens). Megaspores are often equatorially to subequatorially compressed an obvious pyramidal shape of the proximal surface (Figs 13A, 15A, B, 18A, 23A, B, 24B-E, 26B, C, 27A, B, 28A, 29A). The central body is enveloped by a corona $286-940 \mu \mathrm{m}$ wide) in radial dimension. The corona is very delicate and often fragmentarily preserved due to mechanical damage (Figs 13C, F, 15D-I, 18B-G，19B-K，23B-I，24F-M，25，27C-K，28B-K, $29 \mathrm{C}-\mathrm{H}, 30$ ). It consists usually of six to ten (exceptionally more) layers of appendages the touching the central body in narrow zone in the subequatorial area (Figs 15D, E, 18B, 27C-E, 29C). The uppermost layer of the corona occurs in and area of curvature consisting of single appendages and sometimes can resemble a membrane. The width of the appendages is not constant and they can grow together. The bases of appendages are often widest at the base and attached by fine short fibres on the exine surface (Fig. 23G). Sometimes a small cavity can occur at the base of appendages. Appendages are of equal width but in the last third of their length are wide, usually variously entwinted, and not easily differentiated from one another. The margin of an appendage is not continuous and not always smooth, because distal appendages can protrude.

Laesurae is prominent, reaching above the inner margin of the corona. The labrum is narrow and high, often flexuose, and more complex and smooth in its terminal part (Figs 15A, B, 23A, C, 28D). The labrum is thickest in the area where the corona touches the central body. Laesurae can be sculptured by carrot-like or hairy spines of different

Figure 15. Omphalophloios feistmantelii (O. Feistmantel) comb. nov. emend. Tuchlovice Mine, Kladno-Rakovník Basin. NM E2247. Megaspores compared to the dispersed spore species Zonalesporites superbus (Bartlett) Karczewska; all SEM. • A, B - semilateral view showing the elevated rays of the trilete mark, contact area and proximal appearance of the corona. Note the shape of the labrum; scale bar $200 \mu \mathrm{m}$. $\bullet \mathrm{C}-$ distal view showing cylindrical to clavate projections densely covering the entire distal surface. Majority of corona is destroyed; scale bar $200 \mu \mathrm{m}$. $\bullet \mathrm{D}-$ proximal view showing detail of contact area (left part) and corona; scale bar $100 \mu \mathrm{m}$. $\bullet$ E - detail of D. Basal part of first (proximal) corona layer; scale bar $20 \mu \mathrm{m}$. $\bullet \mathrm{F}-$ the surface of the contact area covered by conical spines with very narrow conical tips; scale bar $20 \mu \mathrm{m} . \bullet \mathrm{G}$ - detail of distal surface with club shaped projections coalesced in their terminal parts. Note their smooth surface; scale bar $20 \mu \mathrm{m}$. $\bullet \mathrm{H}, \mathrm{I}$ - details of distal surface with club-shaped projections, some of them are coalesced in their terminal parts. Note their smooth surface $(\mathrm{H})$ and coarse and longitudinally furrowed surface (I); scale bar $20 \mu \mathrm{m}$. $\bullet \mathrm{I}-\mathrm{detail}$ of distal surface with club-shaped projections, some of them are coalesced in their terminal parts. Note their smooth surface; scale bar $20 \mu \mathrm{m}$.

Figure 16. Omphalophloios feistmantelii (O. Feistmantel) comb. nov. emend. Velká opuka tonstein, Ronna Mine, Kladno, Kladno-Rakovník Basin. NM E973. - A - dichotomizing fertile axis; scale bar $10 \mathrm{~mm} . \bullet \mathrm{B}$ - distal surface of microspores of the Cristatisporites splendidus-type. Note the prominent spinae; SEM; scale bar $25 \mu \mathrm{m}$. $\bullet \mathrm{C}$ - detail of photomicrograph B; SEM; scale bar $2 \mu \mathrm{m}$. $\bullet \mathrm{D}$ - distal surface of microspores of the Cristatisporites splendidus-type. Note the prominent spinae; SEM; scale bar $25 \mu \mathrm{m}$. $\bullet \mathrm{E}-$ two microspores of the Cristatisporites splendidus-type. Note the different sculptures of proximal (left specimen) and distal (right specimen); SEM; scale bar $25 \mu \mathrm{m}$. $\bullet \mathrm{F}$ - central body and fragment of a cingulum of a microspore probably of the Densosporites-type. Note the laevigate sculpture and very thin exine of the central body; $\times 500$. $\bullet \mathrm{G}-$ central body of amicrospore probably of the Densosporites-type. Note the prominent trilete mark, laevigate sculpture and very thin exine of the central body; $\times 500$. $\bullet \mathrm{H}$, I, $\mathrm{K}-$ microspores of the Cristatisporites splendidus-type. Note the prominent distal sculpture; all $\times 500$. $-\mathrm{J}$ - distal surface of microspores of the Cristatisporites splendidus-type. Note prominent spinae; SEM; scale bar $25 \mu \mathrm{m} . \bullet \mathrm{L}$ - lateral view of a microspore of the Cristatisporites splendidus-type; SEM; scale bar $25 \mu \mathrm{m}$. 
Jiří Bek et al. • The sub-arborescent lycopsid Omphalophloios from the Middle Pennsylvanian of Bohemia

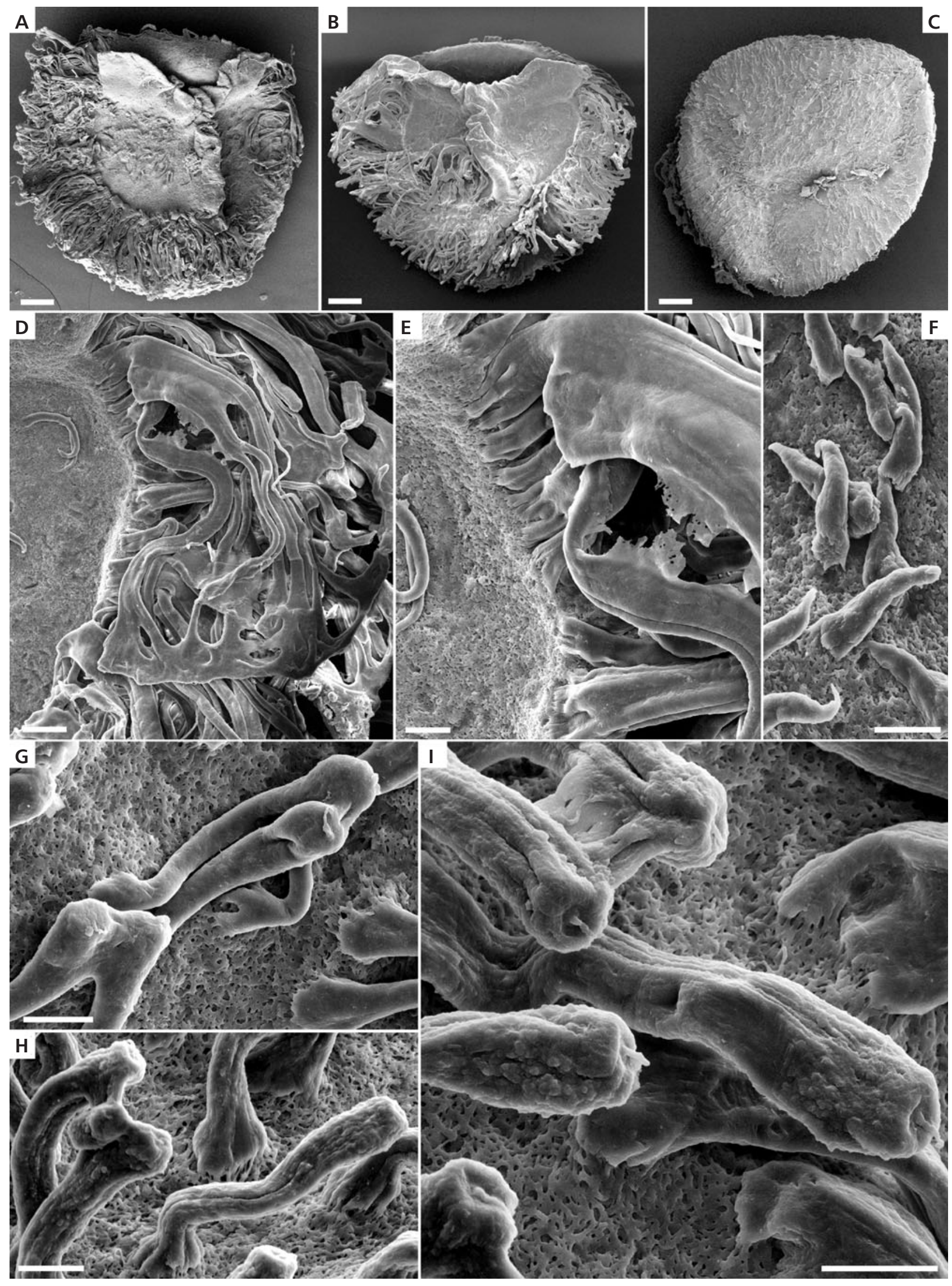




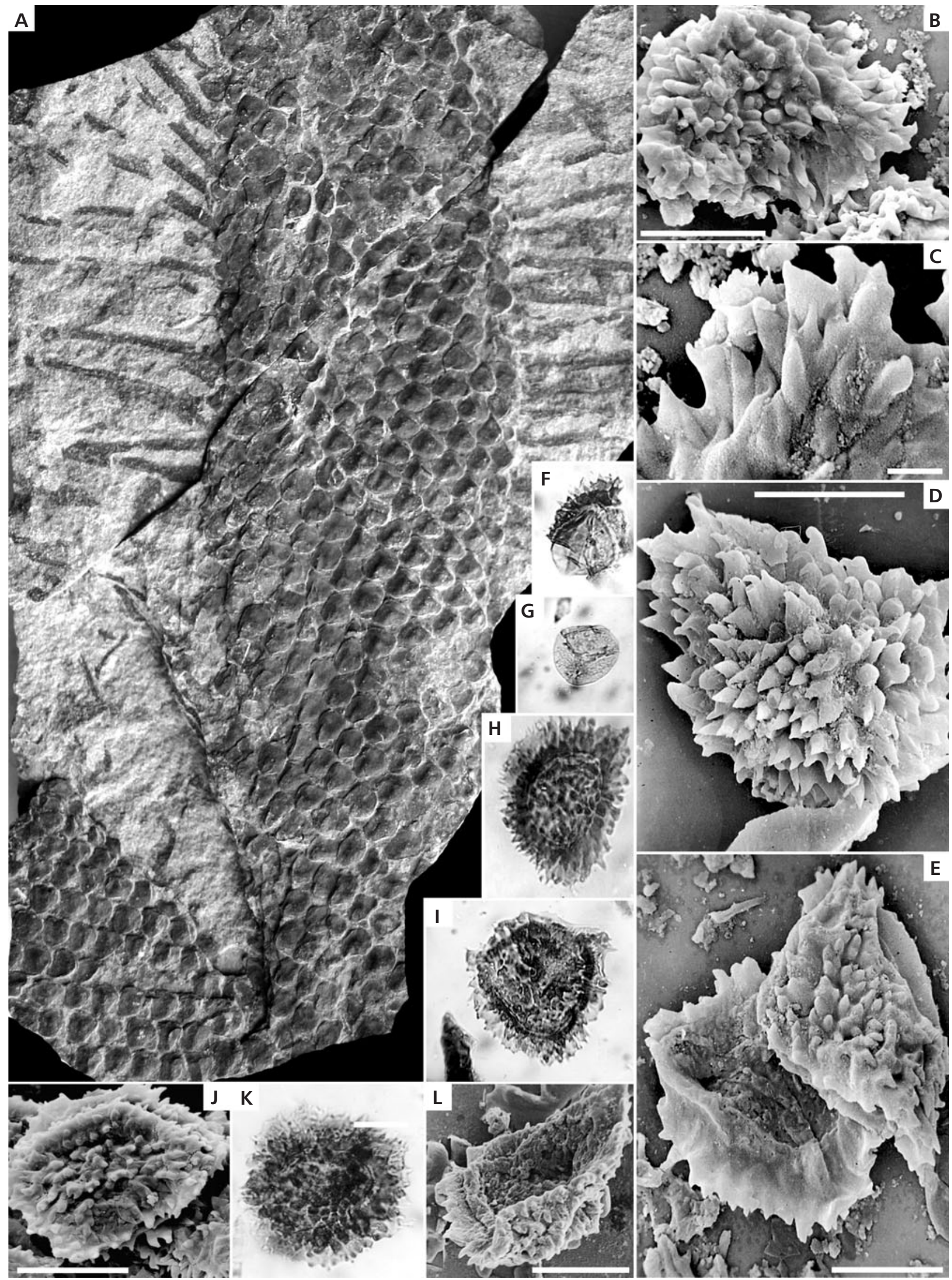



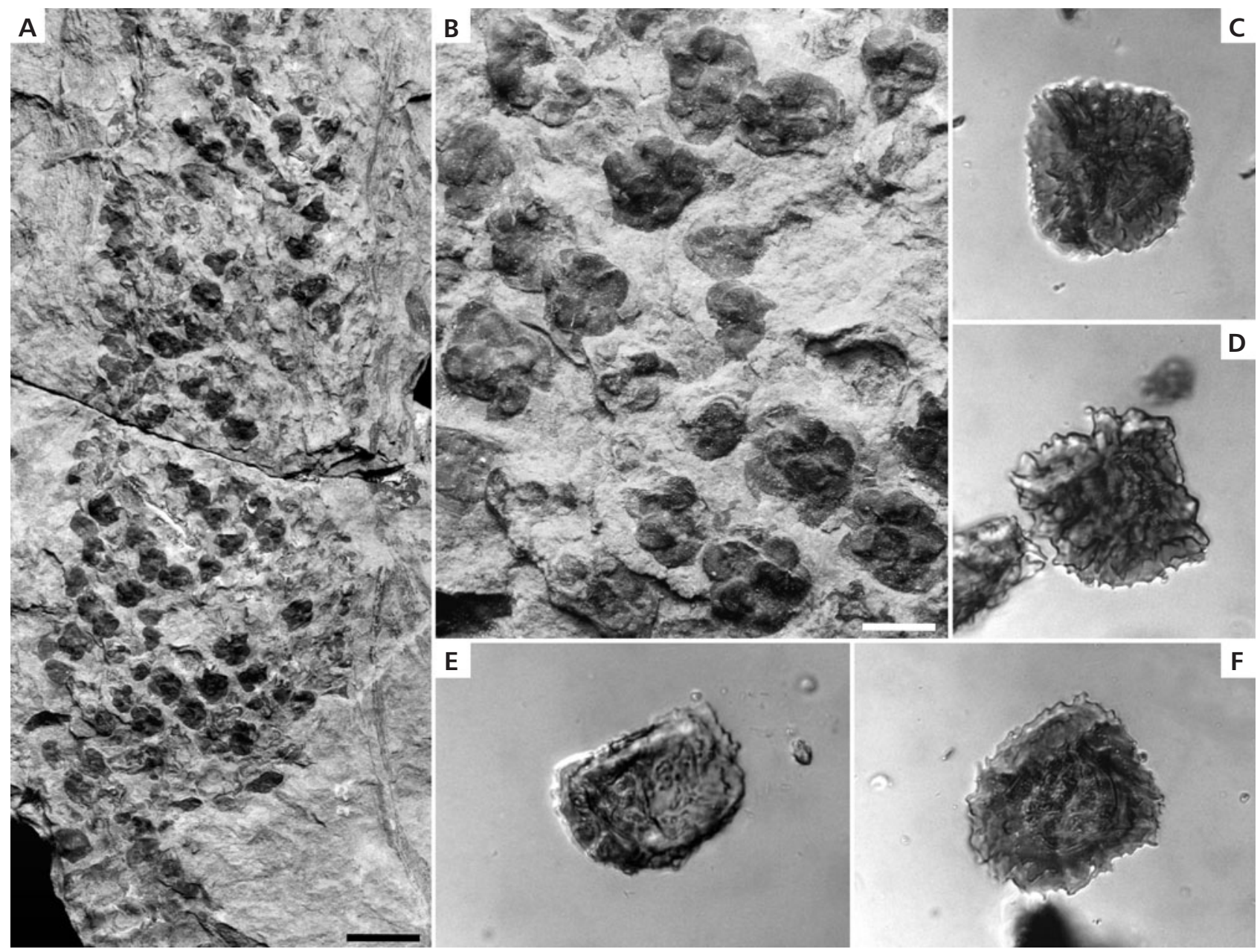

Figure 17. Omphalophloios feistmantelii (O. Feistmantel) comb. nov. emend. One of the Corda's type specimens later redescribed and first figured by O. Feistmantel (1875-1876) in plate LX, fig. 2 as Sigillariaestrobus Feistmanteli. This specimen was selected as the lectotype. NM E974. Břasy, Radnice Basin. $\bullet \mathrm{A}-$ fertile axis bearing micro- and megasporangia preserved in the mudstone; scale bar $10 \mathrm{~mm}$. $\bullet \mathrm{B}-\mathrm{detail}$ of megasporangia of the lectotype; scale bar $3 \mathrm{~mm}$. $・ \mathrm{C}, \mathrm{E}$ - distal surfaces of microspores of the Densosporites-type; all $\times 500$. $\bullet \mathrm{D}$, F - proximal surfaces of microspores of the Densosporites-type; all $\times 500$.

lengths occurring at the laesurae bases. Fine spines occur at terminal margins.

Contact area with spinae and baculae is relatively large. Spines are widest at their bases or in their lowest thirds, tapering towards their narrow apices where they terminate in conical tips. Spines in the equatorial area are longer.

The distal surface of the megaspore is usually covered by cylindrical or club-like appendages (Figs 15C, 19A, 25A, 26B, 27B, 28B, 29B). Distal appendages are prolately cylindrical with rounded blunt or somewhat with swollen apices (Figs 13C, F, G, 15F, G-I, 18C, E, F, 19B, D, F-K, 23F, 24F, I, 25D, E, G, 27K). Their surface is smooth or they are of club-like shape with more or less regular striation. Their sculpture is laevigate, spinate to rugose. Blunts are slightly lapsed to the central depression. Hairy papillae grow from the central area of this depression, which can be $6 \mu \mathrm{m}$ long and strangulated several times (Figs 15I, 19A, D, F, 25G, H). That papillae are integrated that can be seen in the transverse section. Distal appendages are shortest in the polar area, but close to the corona are longer, grow together in layers and usually coincide with the corona. The corona is irregularly perforated from the distal side (Figs 24G, K, L, M, 25B, C).

The exine is 50-60 $\mu \mathrm{m}$ consisting of a basal lamina and the outer layer (Figs 13B, D, E, 26D, F-H).

The basal lamina forms the central body, which possesses a subcircular amb. The central body is 1100 to $1596 \mu \mathrm{m}$ in diameter. Rays of the trilete mark reach almost to the margin of the central body. Lenticular structures occur in the interradial area and are 12-15 $\mu \mathrm{m}$ in diameter. These structures are arranged in ten rows.

In situ megaspores are correlated with the dispersed species Zonalesporites superbus. 


\section{Discussion on spores}

\section{Microspores}

\section{Dispersed densospores}

Cingulate spores of genera Densosporites, Cristatisporites and Cingulizonates are usually included in one group called densospores.

More than thirty dispersed species of Cristatisporites and 80 species of Densosporites are described in the Carboniferous literature (Bek \& Straková 1995).

The genus Densosporites was proposed by Berry (1937) and emended by Butterworth et al. (1964, p. 101) as "spores trilete; outline convexly triangular to subcircular; two-layered; intexine (central body) thin, psilate or faintly roughened, laesurae indistinct, apical papillae sometimes present; proximal surface of outer layer evenly arched or with zona slightly raised above the central proximal area; sutural ridges weak to strong; sometimes connected at their extremities to the zonal region; proximal sculpture generally absent or minor except for scalloping of the zona in some species, faint roughening or granulosity of the central proximal area, and granulaes, spines or apiculae on the zona; sculpture of central proximal area usually differentiated from distal zonal surface, usually granulose; zona psilate, granulose, spinose, apiculose, verrucose etc.; internal vacuoles rare or absent."

The genus Cristatisporites was proposed by Potonié \& Kremp (1954) and emended by Butterworth et al. (1964, p. 108) as: "Spores trilete; outline subcircular to subtriangular; two-layered; intexine often indistinct, when preserved almost fills the exoexinal cavity, sculpture absent-minor; central proximal area of exoexine minutely sculptured, usually surrounded by a loose ring of setae, apiculae, granules or small pits; sutural ridges or grooves often indistinct, terminated by the setose ring; zona beyond the setae psilate or with scattered granules or small apiculae; spore margin irregular with small scattered processes, or strongly incised if the distal sculpture carries to the equatorial margin; distal sculpture prominent, often mamoid or with warts that in part bear setose tips; inner surface of exoexine may be minutely foveolate and vacuolated."

There are some morphologically related and similar genera, like Anulatisporites (Loose) Potonié \& Kremp, Cingulizonates, Radiizonates and Tholisporites Butterworth \& Williams. Several dispersed species assigned originally to Densosporites were transferred later to Cristatisporites, Cingulizonates, Cirratriradites Wilson \& Coe and Anulatisporites. Some species of Anulatisporites, Cirratriradites, Cingulizonates, Cristatisporites, Hymenozonotriletes Naumova and Radiizonates were later

Figure 18. Omphalophloios feistmantelii (O. Feistmantel) comb. nov. emend. Břasy, Radnice Basin. NM E974, lectotype. Megaspores compared to the dispersed spore species Zonalesporites superbus (Bartlet) Karczewska; all SEM. $\bullet$ A - semilateral view showing elevated rays of the trilete mark, contact area, proximal appearance of the corona and clavate projections on the distal part of megaspore; scale bar $500 \mu \mathrm{m}$. $\bullet \mathrm{B}-$ proximal surface with corona, contact area and high, narrow winged laesurae with vertical plications and striation; scale bar $200 \mu \mathrm{m}$. $\bullet \mathrm{C}-\mathrm{detail}$ of A and B. The surface of the contact area covered with spines (some of them are longitudinally grooved striated at the base) with very narrow conical tips; scale bar $20 \mu \mathrm{m}$. $\bullet \mathrm{D}-\mathrm{detail}$ of A. Corona consists of several layers of five to six equatorial appendages. Long cylindrical appendages are not equally wide. Terminal parts are variously grown together; scale bar $100 \mu \mathrm{m}$. $\bullet \mathrm{E}$ - detail of A and B. Upper part of laesurae covered with variously long and wide spines; scale bar $20 \mu \mathrm{m}$. $\bullet \mathrm{F}$ - detail of spines with a microspore of the Densosporites-type; scale bar $20 \mu \mathrm{m}$. $\bullet \mathrm{G}$ - detail of spines of various length and shape; scale bar $100 \mu \mathrm{m}$.

Figure 19. Omphalophloios feistmantelii (O. Feistmantel) comb. nov. emend. Břasy, Radnice Basin. NM E974, lectotype. Megaspores compared to the dispersed spore species Zonalesporites superbus (Bartlett) Karczewska. $\bullet$ A - distal view showing cylindrical to clavate projections densely covering the entire distal surface. The corona is destroyed; SEM; scale bar $500 \mu \mathrm{m}$. $\bullet$ B - detail of A. Terminal parts of distal projections. Note the thin membrane coating the projections; SEM; scale bar $10 \mu \mathrm{m}$. $\bullet \mathrm{C}$ - detail of A showing long narrow cylindrical distal projections; SEM; scale bar $50 \mu \mathrm{m}$. $\bullet \mathrm{D}-\mathrm{detail}$ of A showing terminal parts of distal projections. Note papillae on apexes of projetions; SEM; scale bar $20 \mu \mathrm{m}$. $\bullet$ E - detail of A showing several projections; scale bar. $\bullet \mathrm{F}$ - detail of cylindrical distal projections. Note the hook-like projections and longitudinal furrows on some projections; SEM; scale bar $50 \mu \mathrm{m}$. - G-K - morphological variability of distal projections. Note the hook-like projections on J and K; F scale bar $10 \mu \mathrm{m}$; G-K scale bars $20 \mu \mathrm{m}$.

Figure 20. Omphalophloios feistmantelii (O. Feistmantel) comb. nov. emend. Z-tuff, Filip opencast Mine near Lubná, Kladno-Rakovník Basin. CGS Z $\breve{S} 473$. • A - fertile axis; scale bar $10 \mathrm{~mm}$. • B - detail of A. Note laterally oval sporangia alongside attached obliquely to the axis; scale bar $5 \mathrm{~mm}$. $\bullet \mathrm{C}$ - four microspores of the Densosporites lobatus-type. Note the different sculptures of proximal (left specimen) and distal (right specimen); SEM; scale bar $25 \mu \mathrm{m}$. • D, E, F, G - proximal surfaces of microspores of the Densosporites anulatus (D), Densosporites sphaerotriangularis (E, G) and Densosporites lobatus-type (F). Note the differences among sculpture elements on central body and proximal part of cingulum; all SEM; all scale bars $25 \mu \mathrm{m}$. $\bullet \mathrm{H}, \mathrm{I}-$ tetrads of microspores of the Densosporites-type. Note the different size and number of sculpture elements; both SEM; both scale bars $25 \mu \mathrm{m}$. $\bullet \mathrm{J}$ - three microspores of the Densosporites lobatus-type showing differences among the diameters and sculptures of proximal (right specimen) and distal (upper and lower left specimens) surfaces. Note that the diameter of lower specimen is more than twice smaller than diameter of right specimen; SEM; scale bar $25 \mu \mathrm{m}$. $・ \mathrm{~K}$ - detail of distal sculpture of microspore of the Cristatisporites-type. Note the prominent dense spinae; SEM; scale bar $5 \mu \mathrm{m}$. 
Jiří Bek et al. • The sub-arborescent lycopsid Omphalophloios from the Middle Pennsylvanian of Bohemia
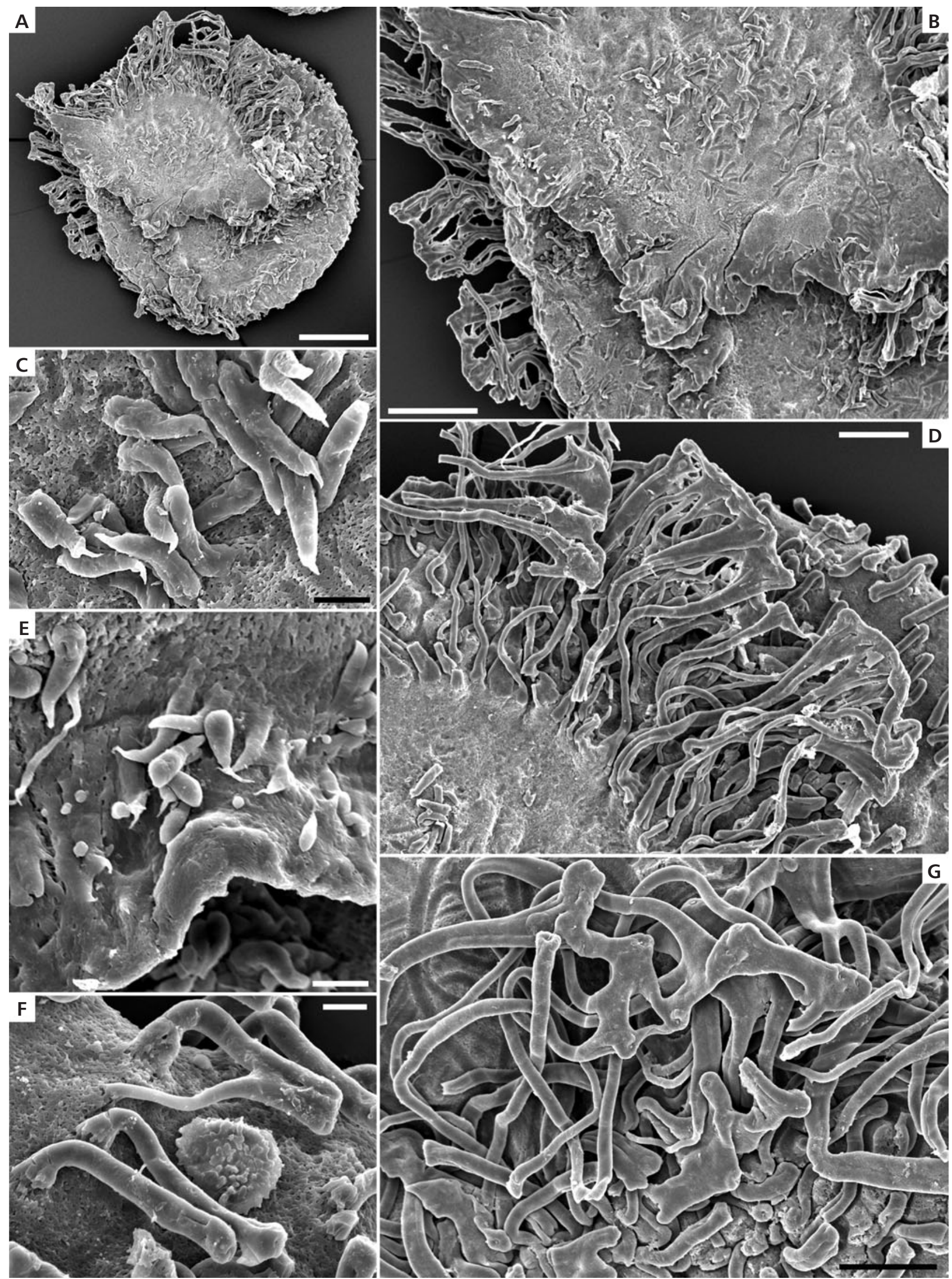

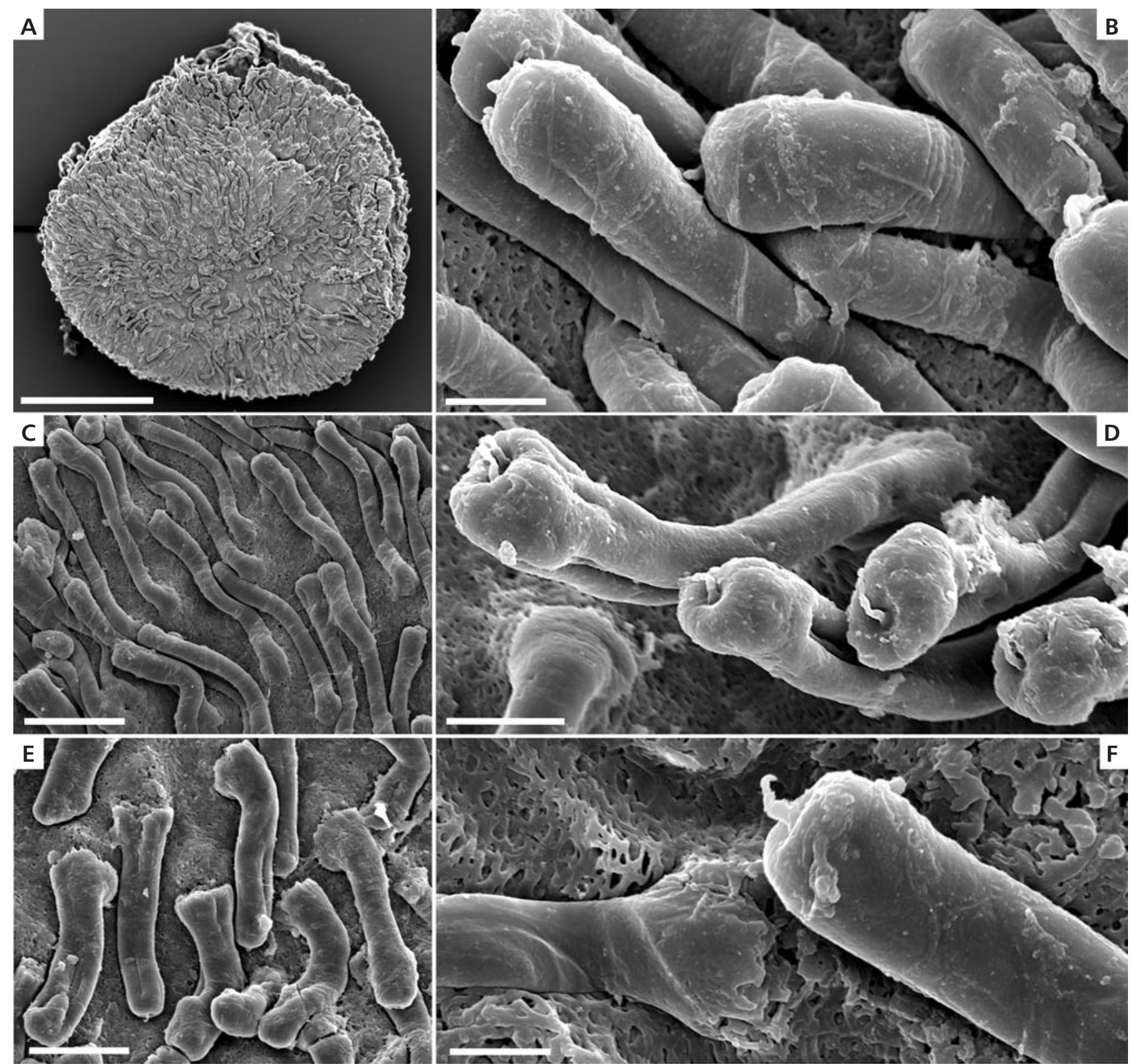

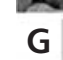

G

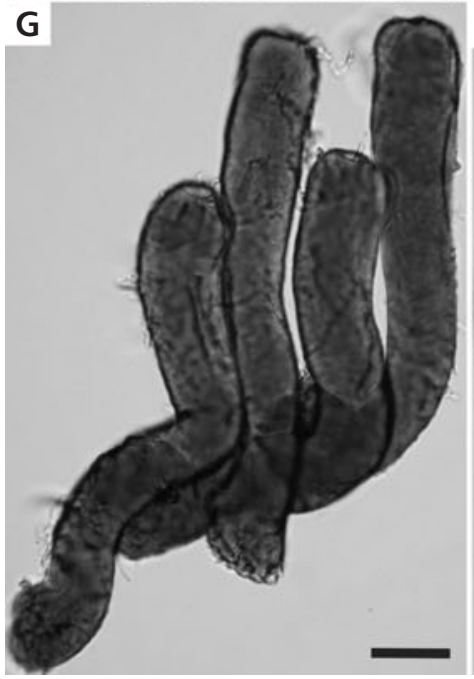

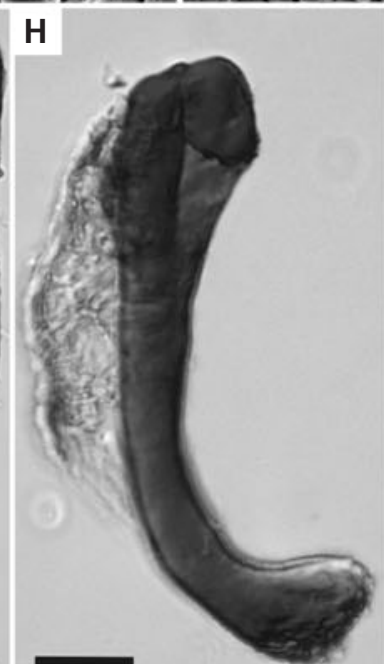
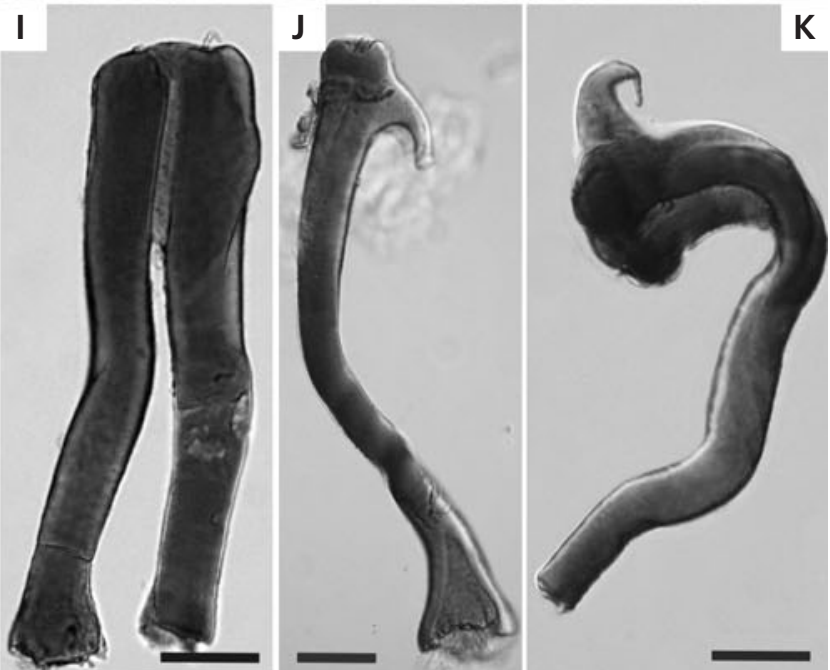


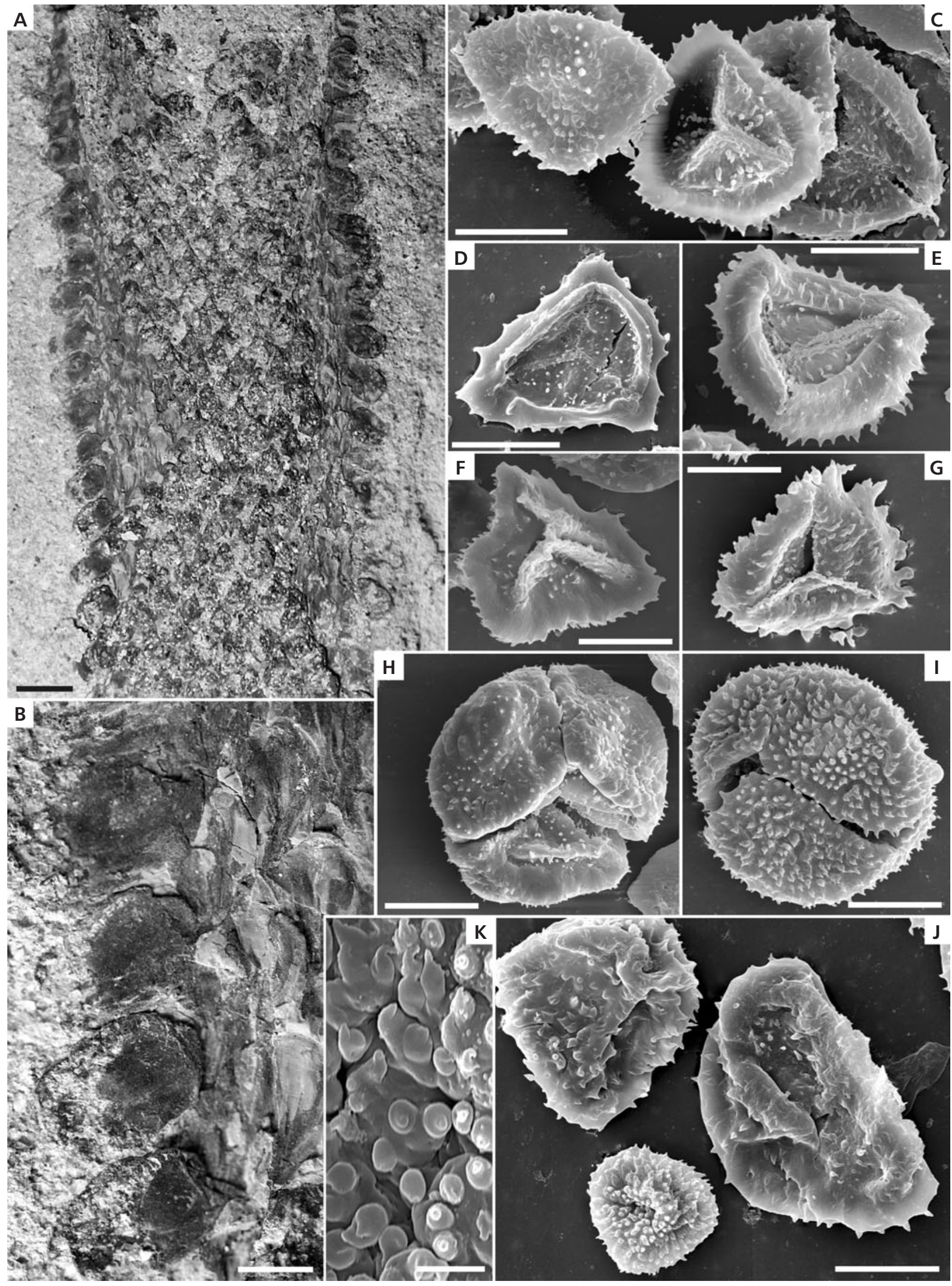


assigned to Densosporites. The classification of some species assigned to Densosporites are/can be questionable usually due to poor descriptions and illustrations, like Densosporites brevispinosus (Waltz) Luber \& Waltz, D. verriculifer (Luber) Luber \& Waltz, D. brachyacanthus (Waltz) Luber \& Waltz, D. subtilis (Waltz) Luber \& Waltz, D. duplicatus (Naumova) Luber \& Waltz, D. ciliaris (Waltz) Luber \& Waltz, D. dentatus (Waltz) Luber \& Waltz, D. fimbriatus (Waltz) Luber \& Waltz, D. heterotomus (Waltz) Luber \& Waltz or D. polyzonalis (Naumova) Luber \& Waltz.

Dispersed spores referred to the genus Tholisporites look very similar to some specimens of Densosporites resembling some laevigate or over-macerated specimens of this genus and might be synonymous with Densosporiteslike Anulatisporites.

From the natural view, almost all varieties that belong to the Carboniferous (and especially Pennsylvanian) dispersed genera Densosporites, Cristatisporites, Anulatisporites and Tholisporites can be traced to microsporangia of one parent plant species and, therefore, represent one biological spore species. It means, that we have specimens of one biological spore species, which belong to several species of four genera in artificial morphological system of the classification of Palaeozoic spores. We cannot be sure about parent plants of some Mississippian densospores, which sometimes look slightly different from most Pennsylvanian densospores.

\section{In situ densospores}

Several of Carboniferous dispersed densospore species can be found in one sporangium or in sporangia of one specimen of Omphalophloios. Densospores represent an example of extreme morphological variation in one natural spore species, encompassing several tens of artificial dispersed species (Leisman 1970, Bek \& Straková 1995). The specific classification of these densospores in dispersed spore assemblages cannot be used as proxy evidence for specific differences among their parent plants. These variations are shown in Figs 7, 12, 14, 16, 17 and 20.

There are only four reports of in situ densospores from plants other than the sub-arborescent Omphalophloios and all of them are from herbaceous lycopsids. Bharadwaj (1958) described Densosporites covensis Berry from sporangia of Porostrobus canonbiensis (Chaloner) Chaloner. Chaloner (1962) described densospores from sporangia of Porostrobus zeilleri Nathorst and Bothrodendrostrobus mundus Hirmer (Chaloner, 1967). Bek \& Leary (2012) isolated microspores of the Cingulizonates-type from the herbaceous lycopsid Porostrobus nathorstii (Leary \& Mickle) Bek \& Leary.

Microspores of the genus Densosporites of Omphalophloios origin were first described as in situ by Bode (1928) from Sporangiostrobus orzechensis and S. rugosus. The same microspores were reported by Němejc (1931) from specimens of S. feistmantelii. Chaloner (1962) mentinoned in situ microspores of the Cristatisporites-type [C. solaris (Balme) Smith \& Butterworth] from Sporangiostrobus ohioensis. Leisman (1970) was the first to show the extreme variation of in situ densospores with microspores isolated from permineralized Sporangiostrobus kansanensis compared with dispersed spores of the genera Densosporites (D. simplex Staplin, D. intermedius Butterworth \& Williams, D. rotatus Staplin), Radiizonates $[R$. rotatus (Kosanke) Staplin \& Jansonius, $R$. aligerens (Knox) Staplin \& Jansonius], Cingulizonates, Cristatisporites and even Vallatisporites. It may be possible that some of these in situ microspores are poorly preserved and/or damaged contributing to such an unusual number of correlated spore genera and species.

Remy \& Remy (1975) erected a new species Sporangiostrobus puertollanesis from the Stephanian of Spain with microspores compared to the dispersed species Densosporites sphaerotriangularis Kosanke.

Coquel \& Brousmiche-Delcambre (1996) also described from $S$. puertollanesis microspores assigned to the dispersed genera Densosporites, Cristatisporites and even Cingulizonates.

Bek \& Straková (1995) described Bohemian in situ densospores (Fig. 7) belonging to the dispersed species Densosporites sphaerotriangularis, D. spinifer, D. cf. spinifer, D. granulosus, D. lobatus, D. glandulosus, D. pseudoannulatus, D. anulatus, D. gracilis and Cristatisporites cf. saarensis. Later Bek \& Opluštil (1998) described in situ densospores from the same parent plant species

Figure 21. Omphalophloios feistmantelii (O. Feistmantel) comb. nov. emend. • A - external mold of a probable fertile axis preserved in silty mudstone and showing rised sporophyll bases with the position of pedicel base. Distal laminae are preserved along the margin (arrow). Břasy, Radnice Basin. NM E6932; scale bar $10 \mathrm{~mm}$. $\bullet \mathrm{B}$ - detail of A; scale bar $5 \mathrm{~mm}$. $\bullet \mathrm{C}$ - external mold of a possibly a vegetative axis showing leaf scars on flat leaf basis. Břasy, Radnice Basin. NM E6934; scale bar $10 \mathrm{~mm}$. $\bullet$ D - detail of C; scale bar $5 \mathrm{~mm}$. $\bullet$ E - endocortical cast of an axis showing outline of slightly raised leaf bases and the position of the scar. Břasy, Radnice Basin, NM E6936; scale bar $10 \mathrm{~mm}$. $\bullet \mathrm{F}$ - specimen showing several modes of preservation. EC - endocortical cast with imperfectly preserved raise outline of leaf basis with scar and remain of internal cortical tissues (a), EM - external mold (separated by dot line from EC) showing imprints of raised leaf bases with a scar (lb) and where sporophyll still complete preserved are imprints of the basal part of distal laminae (1). Břasy, Radnice Basin. NM E6933; scale bar $10 \mathrm{~mm}$. $\bullet \mathrm{G}$ - detail of F showing endocortical cast; scale bar $5 \mathrm{~mm}$. $\bullet \mathrm{H}-\mathrm{detail}$ of F. Note the external mold. Arrow points to the scar; scale bar $5 \mathrm{~mm}$. $\bullet \mathrm{I}$ - endocortical mold showing internal part of cortical tissues with poorly preserved outline of the leaf basis. Břasy, Radnice Basin. NM E6936; scale bar $10 \mathrm{~mm}$. $\bullet \mathrm{J}$ - detail of I; scale bar $5 \mathrm{~mm}$. 


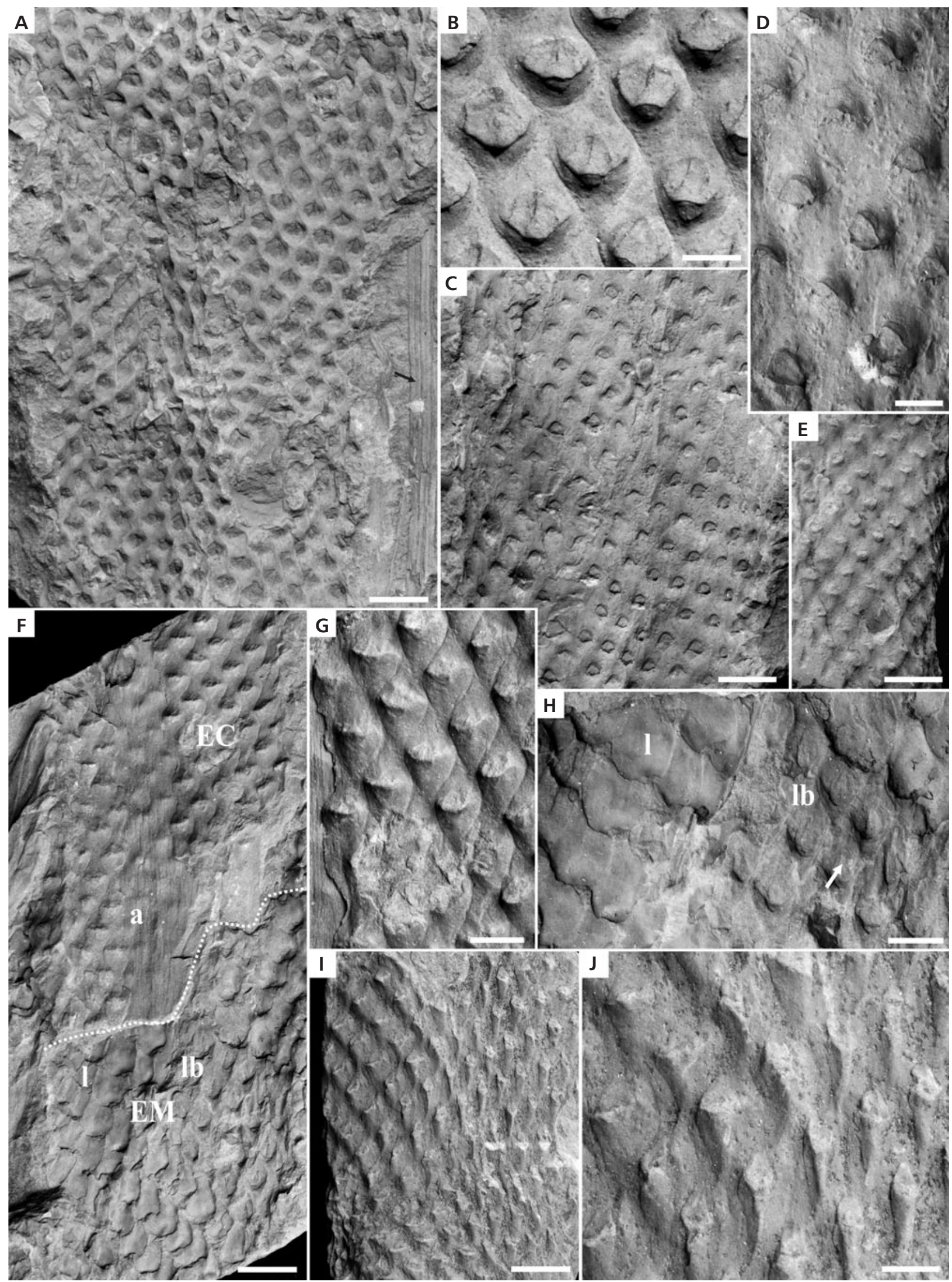




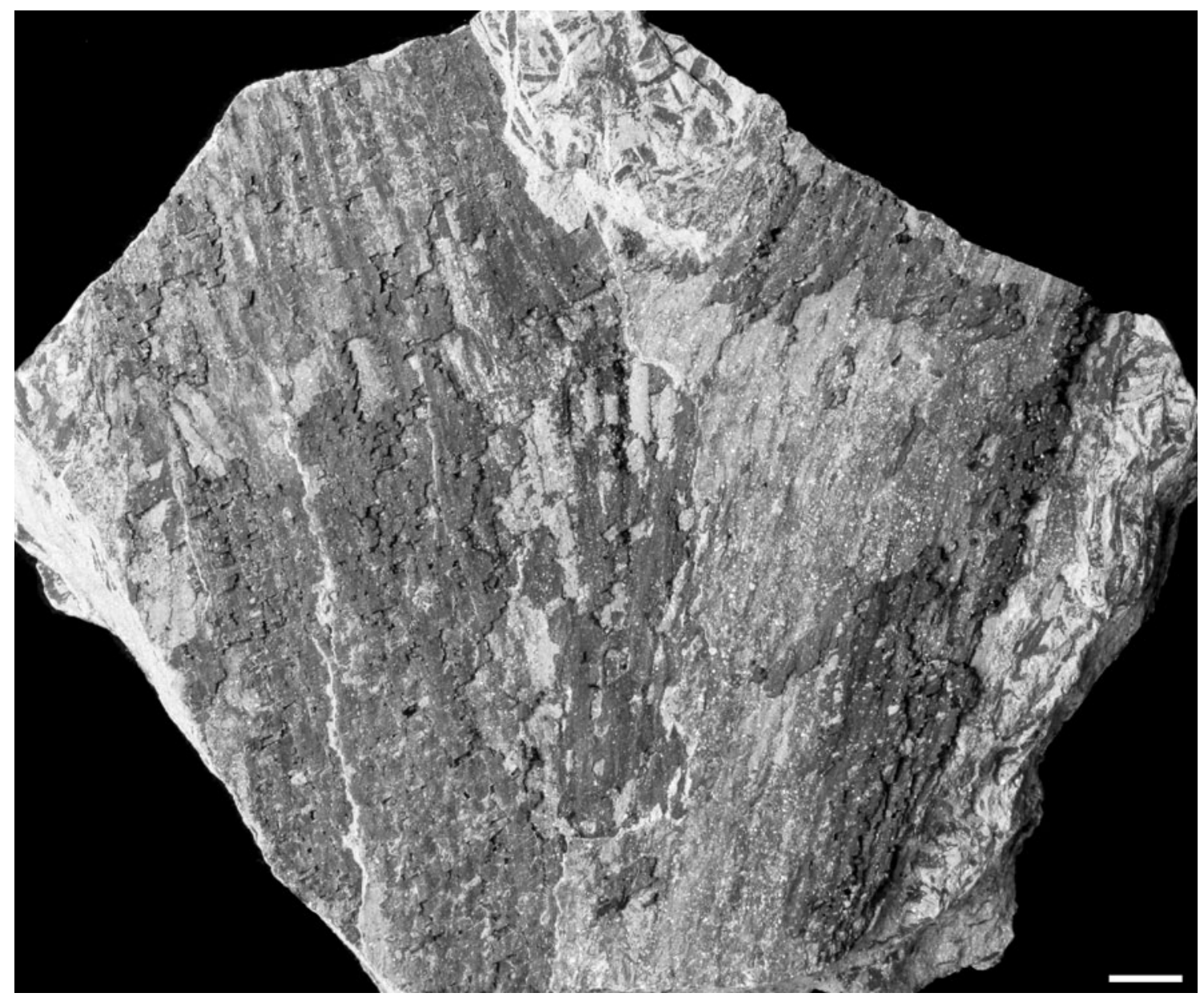

Figure 22. Omphalophloios feistmantelii (O. Feistmantel) comb. nov. emend. Decorticated dichotomizing axis showing endocortical zone with Knorria-type of preservation. Velká opuka tonstein. Tuchlovice Mine, Kladno-Rakovník Basin. CGS ZŠ400; scale bar 10 mm.

Sporangiostrobus feistmantelii and assigned them to the dispersed species Densosporites lobatus, Cristatisporites indignabundus, C. solaris and C. saarensis.

\section{Megaspores}

\section{Dispersed Omphalophloios megaspores}

Coronate megaspores are an important component of Carboniferous microfloras, known from Viséan to Kasimov- ian. They occur in large numbers at some levels and have great stratigraphic value. Coronate megaspores are known from the Devonian [Coronispora variabilis (Fuglewicz \& Prejbisz) Turnau \& Karczewska] but they are smaller with a different structure of corona (Zavailova \& Turnau 2012) from those of the Carboniferous. The study of megaspores of this type in LM and TL was not very successful due to the equatorial corona and thick exine. Their taxonomy is not always clear and precise (Spinner 1965).

Dybová-Jachowicz et al. (1977) followed the detailed study of Karczewska (1975) using three methods: light

Figure 23. Omphalophloios feistmantelii (O. Feistmantel) comb. nov. emend. Velká opuka tonstein, Tuchlovice Mine, Kladno-Rakovník Basin. FS IGP2014/002. Megaspores compared to the dispersed spore species Zonalesporites superbus (Bartlett) Karczewska; all SEM. • A - proximal view showing elevated rays of the trilete mark, contact area and proximal and distal appearance of the corona and clavate projections on the distal part of megaspore (on the left); scale bar $500 \mu \mathrm{m}$. $\bullet \mathrm{B}$ - lateral view; scale bar $500 \mu \mathrm{m}$. $\mathrm{C}$ - detail of A showing the contact area and labrum. Note the prominently undulated labrum with spines; scale bar $100 \mu \mathrm{m}$. $\bullet \mathrm{D}, \mathrm{E}$ - growth of appendaxes of corona in the curvature area; $\mathrm{E}$ - appendages are covered by a thin membrane; scale bars $50 \mu \mathrm{m} \cdot \bullet \mathrm{F}$ - detail of B showing contact area with spines. Note the smooth sharp spines; scale bar $20 \mu \mathrm{m}$. $\bullet \mathrm{G}-$ detail of B showing contact area and cabrum. Note the narrow spines on the labrum and a part of contact area; scale bar $50 \mu \mathrm{m}$. $\bullet \mathrm{H}$ - detail of A showing proximal view of corona. Long narrow appendages are connected in their terminal parts; scale bar $100 \mu \mathrm{m}$. $\mathrm{I}-$ distal view. Distal clavate appendages growing and merged together with corona; scale bar $100 \mu \mathrm{m}$. 

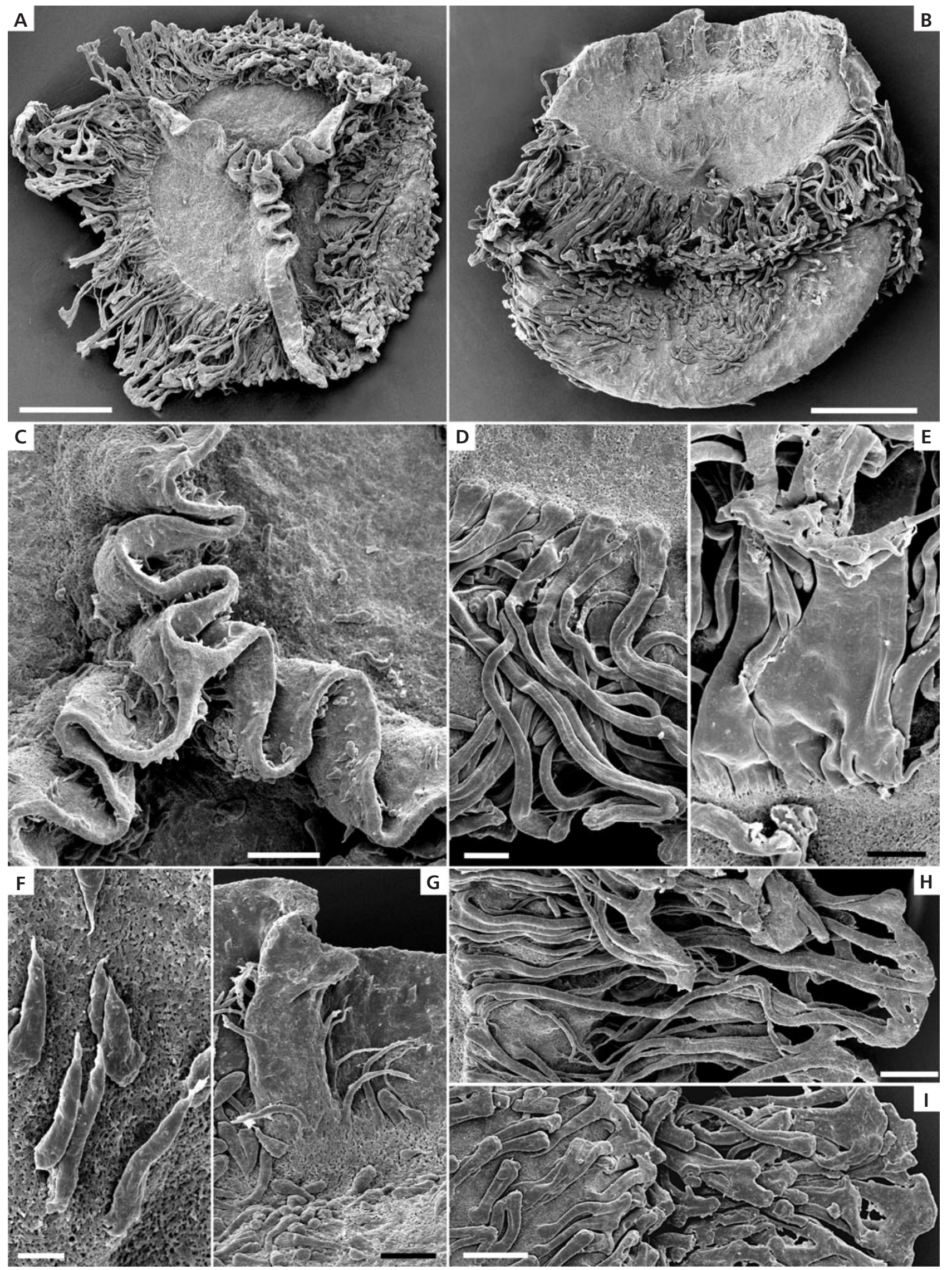
(LM) and transmitted (TL) microscopy and SEM. The result was the revision of this complicated group of megaspores. Dybová-Jachowicz et al. (1977) suggested three genera, Zonalesporites Ibrahim, Radiatisporites Potonié \& Kremp and Rotatisporites Potonié \& Kremp. The ultrastructure of the exine of some coronate megaspores (Zonalesporites, Rotatisporites) from the Illinois and Moscow basins was studied with TEM by Glasspool et al. (2000, 2009).

The genus Zonalesporites was proposed by Ibrahim (1933) and emended by Potonié \& Kremp (1954) for zonate or coronate trilete megaspores. Dybová-Jachowicz et al. (1977) mentioned as synonymous genera Macrosporites Renault, Superbisporites Potonié \& Kremp (in part), Megatrymenozonales Ischenko \& Semenova (in part) and Coronatisporites Loboziak.

Dybová-Jachowicz et al. (1977) supposed that the dispersed species Sporites clavatopilosus Wicher and Superbisporites superbus (Bartlett) Potonié \& Kremp are synonymous to Zonalesporites superbus.

The assignment of coronate megaspores suggested by Potonié \& Kremp (1954) was often far from certain, which was the reason why Spinner (1965) expanded and emended the diagnosis of Zonalesporites.

Zonalesporites superbus was defined by Bartlett (1928, p. 20 as Triletes superbus Bartlett) based on LM study and, therefore it was not possible to recognise proximal and distal sculptures. Arnold (1961, p. 24) revised this material, studied proximal and distal surfaces and emended the diagnosis.

The genus Rotatisporites was erected by Potonié \& Kremp (1954) and emended by Dybová-Jachowicz et al. (1977) to accommodate megaspores in which the corona consists of bifurcated or dichotomosous fibrils that grows together to forms the ring with spinules and clavules. Synonymous were given as Superbisporites (in part) and Megahymenozonales Ischenko \& Semenova (in part).

Dybová-Jachowicz et al. (1977) synonymised Triletes ramosus Arnold and Superbisporites dentatus Potonié \& Kremp with Rotatisporites dentatus (Zerndt) DybováJachowicz et al., which is supported by Dijkstra (1952) who noted that Triletes ramosus proposed by Arnold (1950) is closely similar to Triletes dentatus and mentioned that the only difference is their stratigraphical levels.

\section{In situ Omphalophloios megaspores}

All known megaspores isolated from Omphalophloios are thick-walled with a central body enveloped by an equatorial zona consisting of mass of appendages creating a corona. In situ megaspores of the Zonalesporites-type were described for the first time by Němejc (1931) from Bohemian

Figure 24. Omphalophloios feistmantelii (O. Feistmantel) comb. nov. emend. preserved in the Z-tuff. Lubná, Kladno-Rakovník Basin. CGS ZŠ 478. In situ megaspores compared to the dispersed spore species Zonalesporites superbus (Bartlett) Karczewska; A-C - reflected light. D-K, M SEM. • A - fragment of fertile axis bearing micro- and megasporangia; scale bar $10 \mathrm{~mm}$. $\bullet$ B, C - proximal (B) and distal view (C) of the same megaspore specimen; scale bar $500 \mu \mathrm{m}$. $\bullet \mathrm{D}, \mathrm{E}$ - semilateral views of megaspores. Note (D) proximal (right) and distal appearance of folded corona (middle); scale bar $500 \mu \mathrm{m}$. - F, I - detail of contact area. Spines are simple or grow together at the base. Spines can be rough with unclear longitudinally wrinkled spines terminated by laevigate narrow conical tips; scale bar $20 \mu \mathrm{m}$. $\bullet \mathrm{F}$ - the surface of contact area covered by rough longitudinally wrinkled spines; scale bar $20 \mu \mathrm{m}$. - G, H, M - proximal views of corona. First layer is dissected, formed by projections and terminally coalesced (G); scale bar $50 \mu \mathrm{m}$. The layer can be partially membranous $(\mathrm{H})$, or it has nearly membranous appearance $(\mathrm{M})$; scale bar $200 \mu \mathrm{m}$. $\bullet \mathrm{J}$ - detail of corona (break away); scale bar $200 \mu \mathrm{m}$. $\bullet \mathrm{K}$ - detail of corona (distal view); scale bar $100 \mu \mathrm{m}$. $\bullet \mathrm{L}$ - membranous appearance of corona; scale bar $20 \mu \mathrm{m}$.

Figure 25. Omphalophloios feistmantelii (O. Feistmantel) comb. nov. emend. preserved in the Z-tuff. Lubná, Kladno-Rakovník Basin. CGS ZŠ 478. Megaspores compared to the dispersed spore species Zonalesporites superbus (Bartlett) Karczewska; all SEM. A-C reflected light; D-M SEM. • A - distal view (details are on B-F). Corona and distal projections (partly broken); scale bar $500 \mathrm{~mm}$. $\bullet$ B - detail of (A) showing distal projections growing together. Distal appendages can cover corona; scale bar $200 \mu \mathrm{m}$. $\bullet \mathrm{C}$ - detail of distal surface of corona. Note the papillae visible on the distal surface of corona (the same as on distal projections); scale bar $100 \mu \mathrm{m}$. $\bullet \mathrm{D}$ - distal appendages growing together longitudinally or in their apical parts. Note terminal papillae and different pattern of growing together of appendages; scale bar $50 \mu \mathrm{m}$. $\bullet$ E- distal projections growing together and reach corona; scale bar $50 \mu \mathrm{m} . \bullet \mathrm{F}$ - detail of rough distal surface (A). Note scars of broken appendages; scale bar $20 \mu \mathrm{m}$. $\bullet \mathrm{G}$ - distal surface densely covered by single or mutually growing together sculptured projections. Note their hook-like appearance; scale bar $20 \mu \mathrm{m}$. $\bullet \mathrm{H}-$ detail of G. Note the prominently sculptured terminal part of the projection and several times compressed central papillae; scale bar $5 \mu \mathrm{m}$.

Figure 26. Omphalophloios feistmantelii (O. Feistmantel) comb. nov. emend., preserved in the Z-tuff. Lubná, Kladno-Rakovník Basin. CGS ZŠ 476. Megaspores compared to the dispersed spore species Zonalesporites superbus (Bartlett) Karczewska; A, B reflected light; C-H SEM. • A - fragment of fertile axis bearing megasporangia with attached distal laminae; scale bar $10 \mathrm{~mm}$. $\bullet \mathrm{B}-$ lateral view. Note the densely ornamented distal surface; scale bar $500 \mu \mathrm{m} . \bullet \mathrm{C}$ - distal view. Broken megaspore. View on the proximal wall of megaspore from its inner side. Inner body and trilete mark are visible; scale bar $500 \mu \mathrm{m}$. • D - transversally broken megaspores; scale bar $500 \mu \mathrm{m}$. $\bullet \mathrm{E}$ - note the lenticular structures in interradial area; scale bar $200 \mu \mathrm{m}$. $\bullet \mathrm{F}-$ detail of D. Note fractured appendages of corona (left); scale bar $20 \mu \mathrm{m} . \bullet \mathrm{G}$ - detail of D. Note the cross-section of labrum and different thickness of proximal and distal walls of megaspore; scale bar $20 \mu \mathrm{m}$. $\bullet \mathrm{H}$ - detail of $\mathrm{G}$; scale bar $35 \mu \mathrm{m}$. 
Jiří Bek et al. • The sub-arborescent lycopsid Omphalophloios from the Middle Pennsylvanian of Bohemia

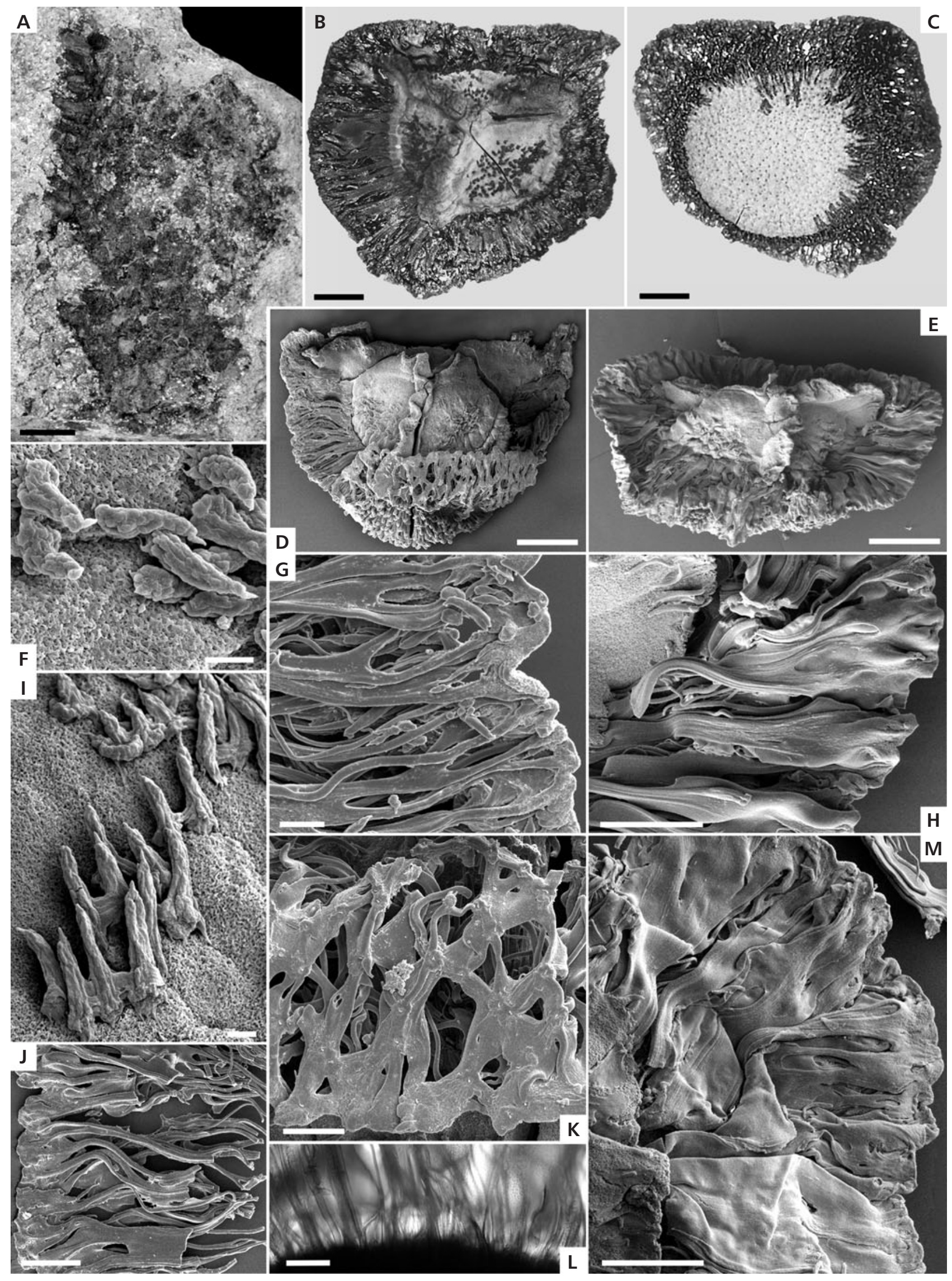





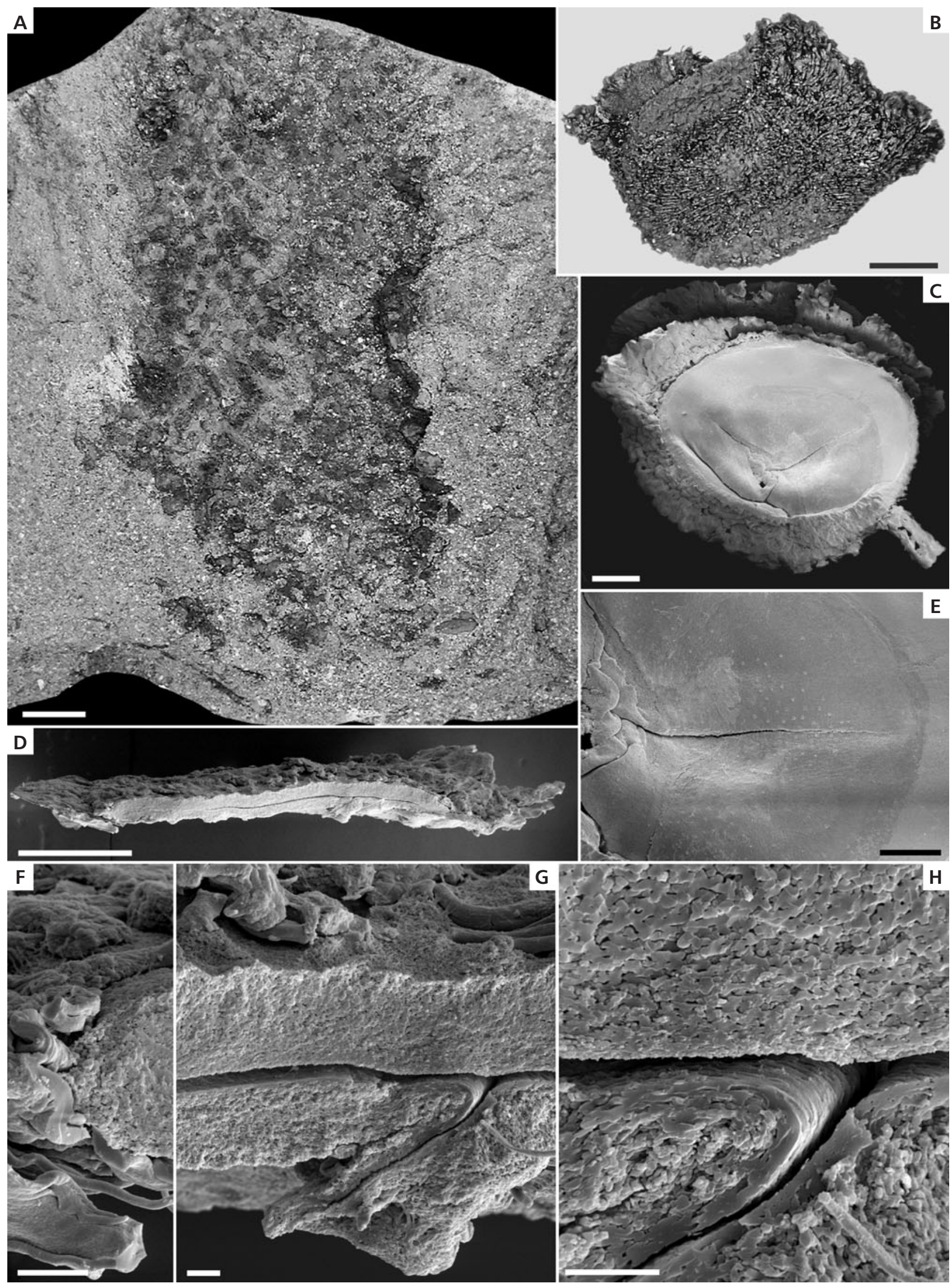
specimens of Sporangiostrobus feistmantelii. In situ megaspores of the Zonalesporites superbus-type were described from Sporangiostrobus langfordii (Chaloner 1956), S. ohioensis (Chaloner 1962) and S. kansanensis (Leisman 1970). Brousmiche-Delcambre et al. (1995) described in situ megaspores of the Superbisporites dentatus-type from a specimen of Omphalophloios cyclostigma.

Megaspores were macerated from fourteen specimens from three localities in the Czech Republic: Tuchlovice Nosek Mine, Břasy (lectotype) and Lubná. They were isolated from the lectotype from the Břasy locality showing that those macerated from the Lubná locality differ mainly in the diameter and in the development of sculpture elements. Megaspores from specimens from the Tuchlovice Nosek Mine locality possess distal appendages of various morphological variations. Some appendages are smooth, some of them rugose and others are of the transitional type. It is evident, that sculpture elements of one megaspore species vary. Also differences in diameter are not indicative of different megaspore species, because the diameter of megaspores isolated from several specimens from one locality is variable. Based on these facts in situ megaspores isolated from specimens from the three localities mentioned above can be correlated with the same dispersed spore species, Zonalesporites superbus.
Megaspores described by Chaloner (1956) from Sporangiostrobus langfordi and Chaloner (1962) from S. ohioensis were compared with the dispersed species Zonalesporites superbus, but they differ from those isolated from Omphalophloios feistmanteli in having a more continuous lace-like structure to the corona.

Also Leisman (1970) assigned megaspores macerated from Sporangiostrobus kansanensis to the dispersed spore species Zonalesporites superbus. But these megaspores are generally smaller than average for this species and possess smaller laesurae, a narrower and more massive corona and lack distal ornamentation. In fact, megaspores isolated from $S$. kansanensis are similar to the dispersed species Zonalesporites brasserti (Stach \& Zerndt) Potonié \& Kremp, as mentioned by Bartram (1987, p. 196). They should, however, be treated as Zonalesporites cf. brasserti because they are larger than most specimens of this species (their diameter is between average diameters of Z. superbus and Z. brasserti).

Brousmiche-Delcambre et al. (1995) described megaspores isolated from two sporangia of topotypes (no microsporangia were found) of Omphalophloios cyclostigma, which were assigned to the dispersed species Superbisporites dentatus (Zerndt) Potonié \& Kremp. Two of us sampled (JB) and macerated (JD) megaspores from the same specimens of $O$. cyclostigma in the collection of

Figure 27. Omphalophloios puertollanensis Wagner, Emma Mine, $3^{\text {rd }}$ Seam, Puertollano Basin, Spain. CGS ZŠ 537 and NM E390. In situ megaspores classified as Zonalesporites cf. superbus (Bartlett) Karczewska; all SEM. • A - proximal view showing the elevated rays of the trilete mark, contact area and proximal and partially distal tappearance of the corona (folded part on the right); scale bar $500 \mu \mathrm{m}$. $\bullet \mathrm{B}-$ distal view; scale bar $500 \mu \mathrm{m}$. $\bullet \mathrm{C}-\mathrm{detail}$ of $\mathrm{A}$ showing surface of corona. Note the mebrane appearance of the first proximal layer of corona; scale bar $100 \mu \mathrm{m}$. $\bullet$ D - detail of B showing distal surface of corona. Note the mebrane appearance of the first proximal layer of corona; scale bar $200 \mu \mathrm{m}$. $\bullet \mathrm{E}$ - detail of A showing the proximal membranaceous appearance of corona. Note the openings in their terminal part of mebrane; scale bar $100 \mu \mathrm{m} . \bullet \mathrm{F}$ - detail of B, D (left); notice detailed structure of corona and papillae (white objects); scale bar $20 \mu \mathrm{m} . \bullet \mathrm{G}$ - detail of labrum (left) and contact area (right). Note the spines; scale bar $20 \mu \mathrm{m}$. $\bullet \mathrm{H}-\mathrm{detail}$ of distal part of corona. Note the margin of corona; scale bar $100 \mu \mathrm{m}$. $\bullet \mathrm{I}, \mathrm{J}$ - detail of distal appendages in the basal part of corona and near corona; scale bar $50 \mu \mathrm{m}$. - K - distal clavate projection. Note the terminal papillae; scale bar $20 \mu \mathrm{m}$.

Figure 28. Omphalophloios cyclostigma (Lesquereux) White, topotypes Pitcher's coal mine in Henry County, Missouri, Washington D.C., USA. USNM 606556. In situ megaspores (USNM 606556-1) compared to the dispersed spore species Rotatisporites dentatus (Zerndt) Dybová-Jachowicz et al.; G-light microscope; A-F, H-K SEM. • A - proximal view showing elevated rays of the trilete mark, contact area, proximal and distal appearance of corona and distal surface; scale bar $500 \mu \mathrm{m}$. $\bullet \mathrm{B}$ - tetrad of megaspores showing distal surface and corona; scale bar $500 \mu \mathrm{m}$. $\bullet \mathrm{C}$ - megaspore broken in the equatorial plane. View from the inner proximal side. Note the shape of central body with trilete mark; scale bar $500 \mu \mathrm{m}$. $\bullet \mathrm{E}-\mathrm{detail}$ of A. Distal view of corona; scale bar $100 \mu \mathrm{m}$. $\bullet \mathrm{F}$ - detail view of A showing sculptural elements of the corona; scale bar $100 \mu \mathrm{m}$. $\bullet \mathrm{G}-$ separated projections of corona. Note the expanded and ring-like structure in terminal part; scale bar $50 \mu \mathrm{m}$. $\bullet \mathrm{H}$ - detail of B showing distal surface; scale bar $50 \mu \mathrm{m}$. $\bullet \mathrm{I}-$ detail of A showing marginal part of corona. Note the finger-like appendages on their margins; scale bar $50 \mu \mathrm{m} . \bullet \mathrm{J}$ - detail of C showing the central body (thin laevigate on the left). Note the stratification of exine; scale bar $50 \mu \mathrm{m}$. $\bullet \mathrm{K}$ - detail of finger-like appendages the margin of the corona. Note the punctate surface; scale bar $20 \mu \mathrm{m}$.

Figure 29. Omphalophloios sp. Specimen from the roof shale of the Lower Block (early Moscovian) of the Illinois Basin, USA. In situ megaspores compared to the dispersed spore species Zonalesporites brasserti (Stach \& Zerndt) Dybová \& Jachowicz; all SEM. • A - semilateral view showing elevated rays of the trilete mark, contact area, proximal appearance of the corona and clavate projections on the distal surface; scale bar $200 \mu \mathrm{m}$. $\bullet$ B - tetrad of megaspores showing distal surface and corona; scale bar $200 \mu \mathrm{m}$. $\bullet \mathrm{C}$ - proximal view. Contact area ornamented by spines; scale bar $50 \mu \mathrm{m}$. $\bullet \mathrm{D}-\mathrm{lateral}$ view. Detail of laesurae, contact area and distal surface of corona in radial region (lower); scale bar $50 \mu \mathrm{m}$. $\bullet$ E - detail of B showing distal surface of corona; scale bar $20 \mu \mathrm{m}$. $\bullet \mathrm{F}$ - detail of B showing distal surface of corona; scale bar $5 \mu \mathrm{m}$. $\bullet \mathrm{G}$ - detail of B and C. Note the smooth surface of the distal pole; scale bar $20 \mu \mathrm{m}$. $\bullet \mathrm{H}$ - detail of B showing the distal surface close to corona with tubercules and simple appendages with sharp ends; scale bar $20 \mu \mathrm{m}$. 

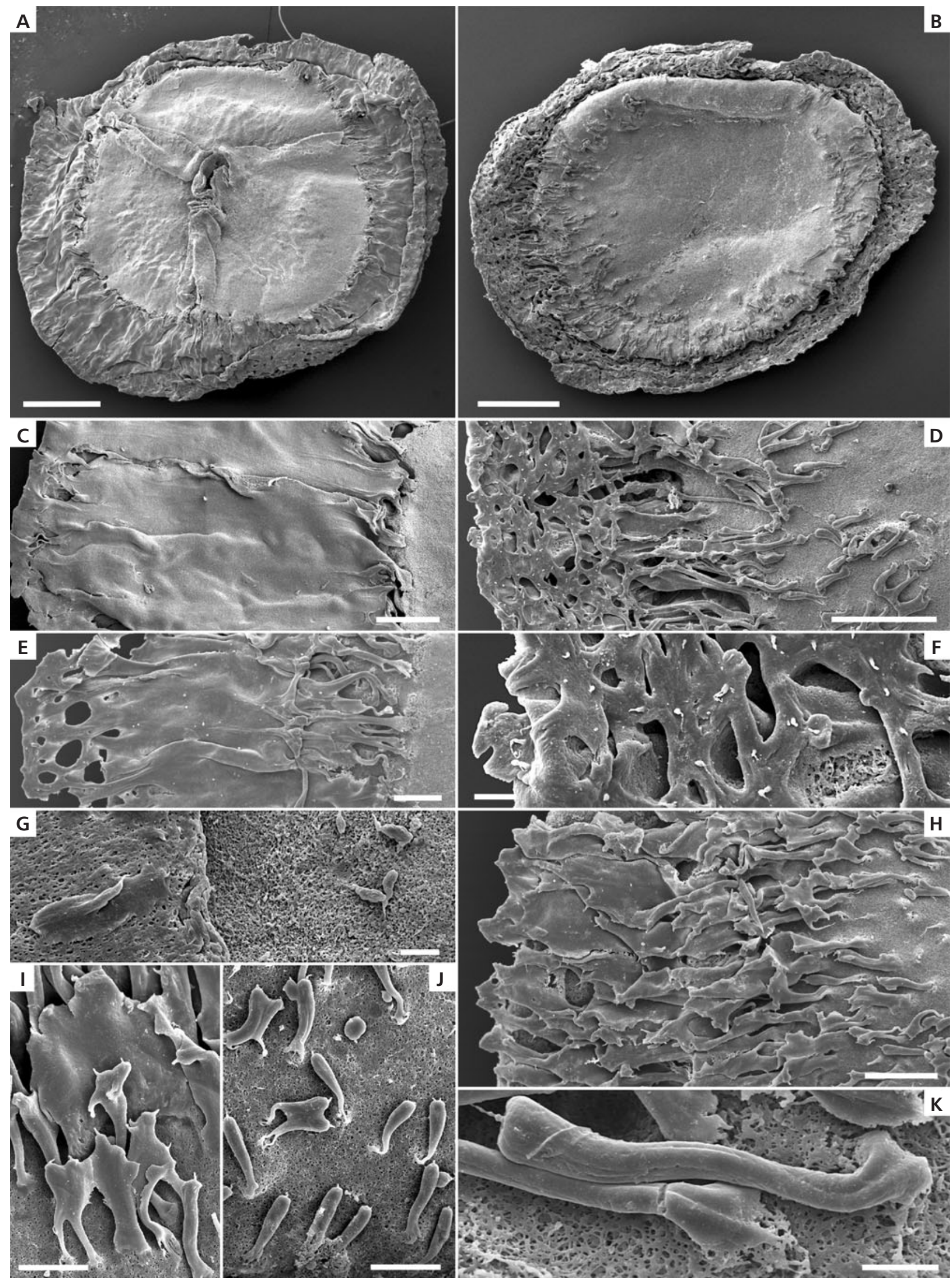

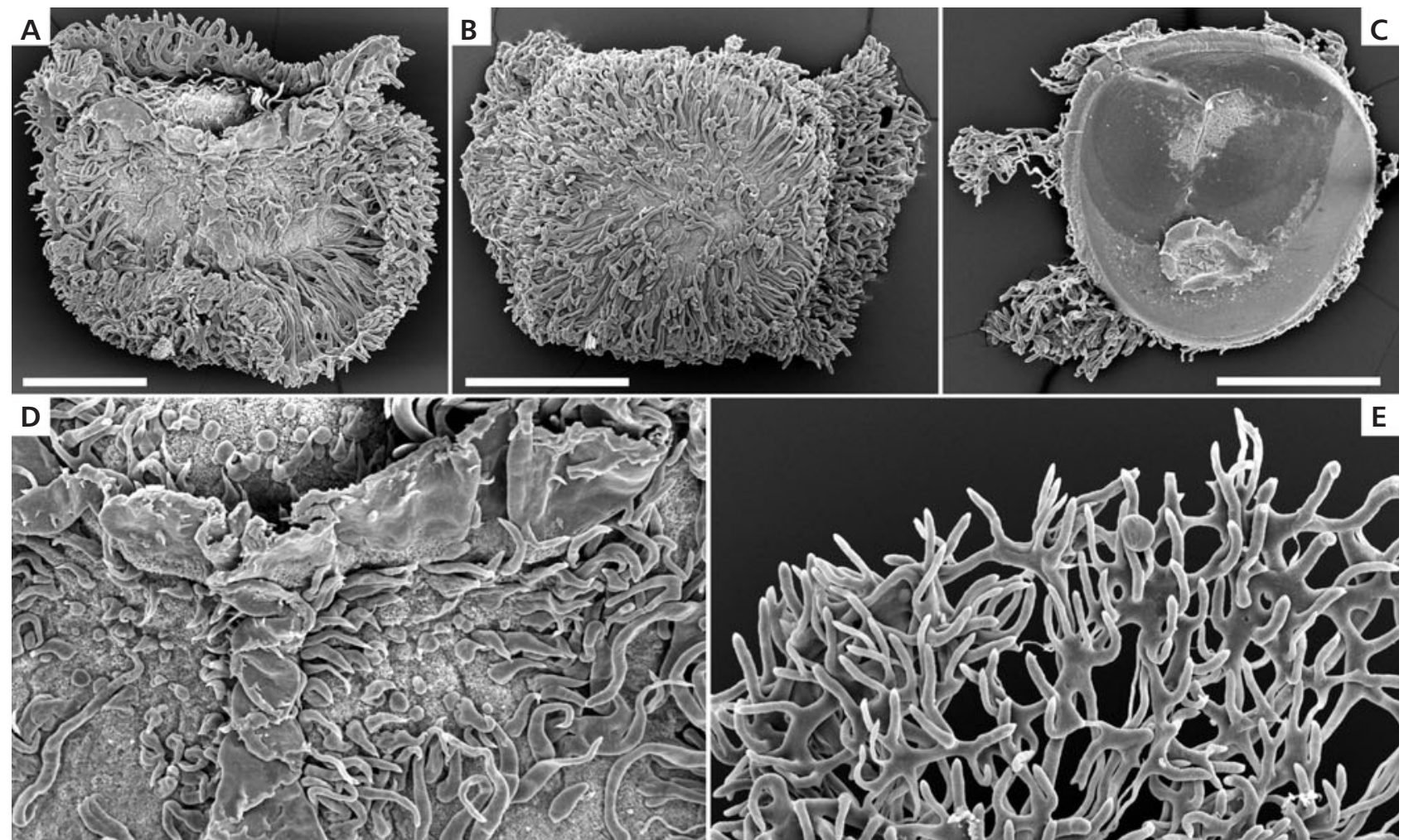

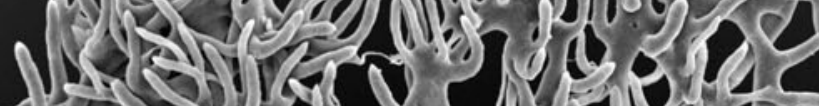

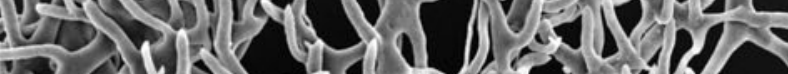

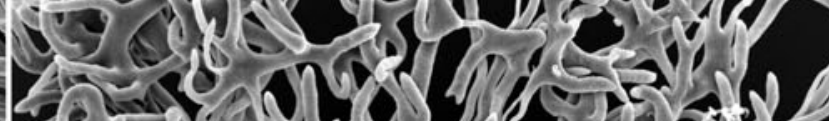

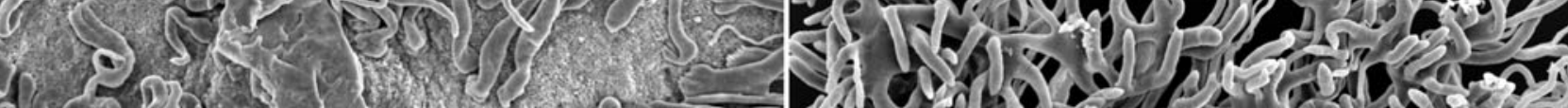

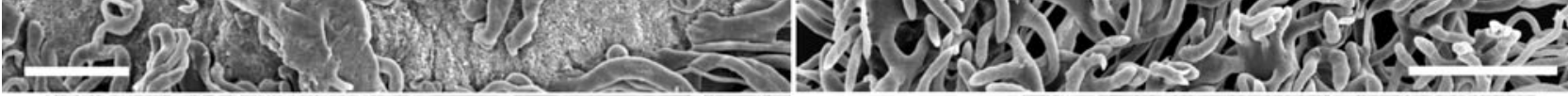

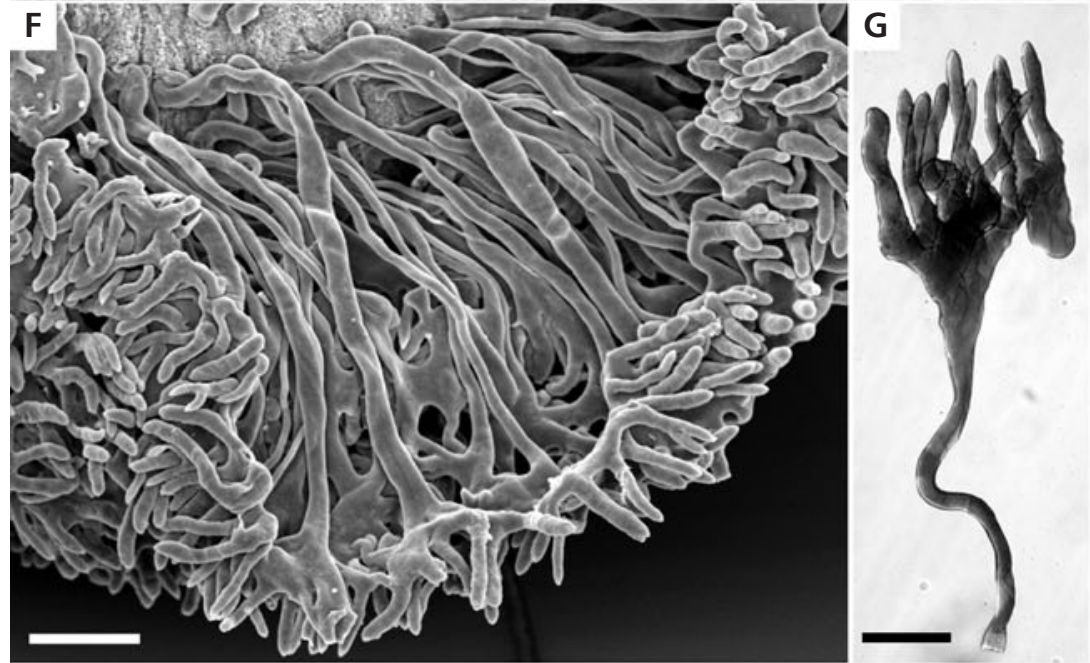

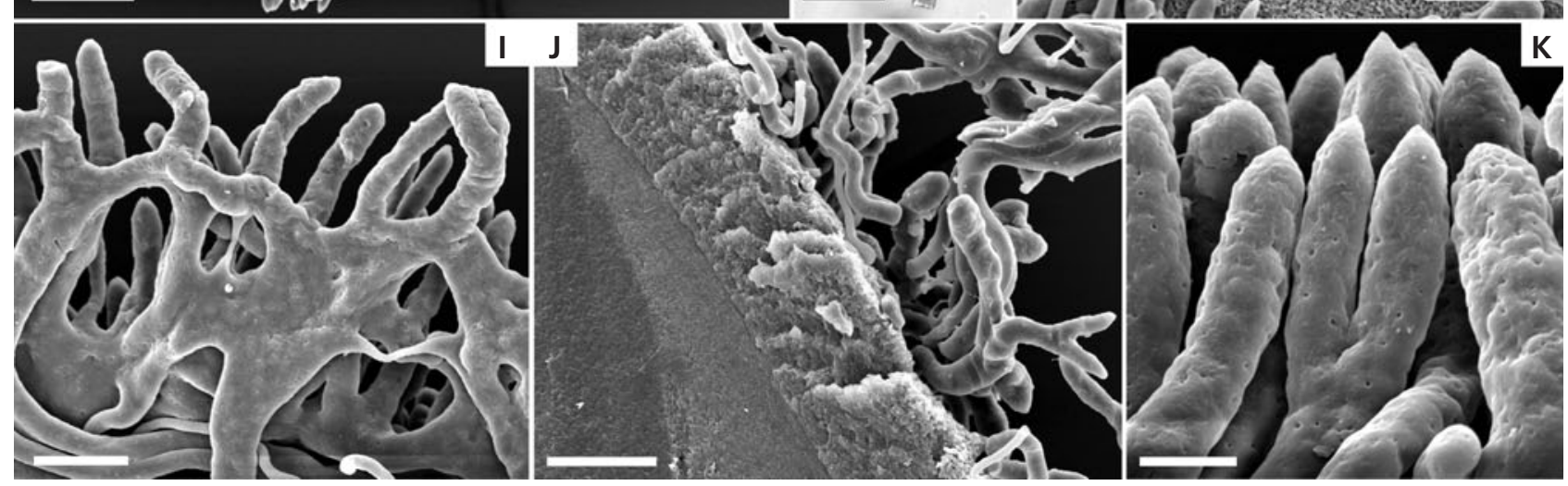


Jiří Bek et al. • The sub-arborescent lycopsid Omphalophloios from the Middle Pennsylvanian of Bohemia
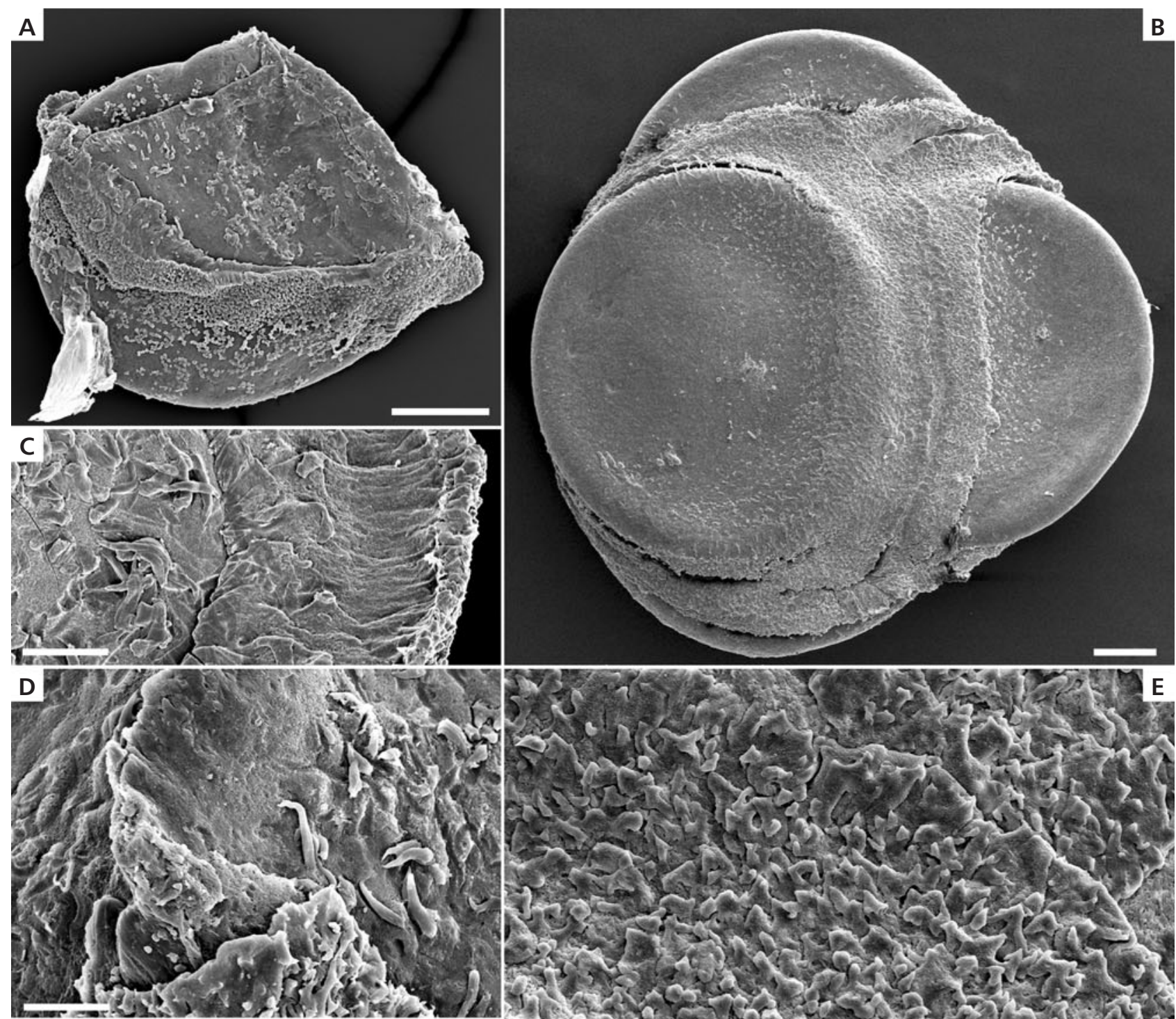

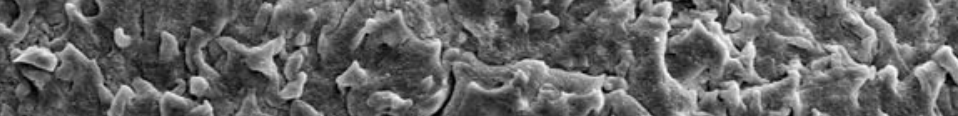

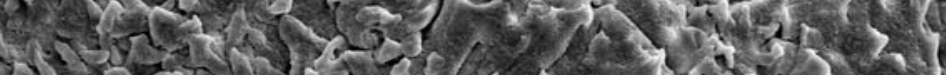

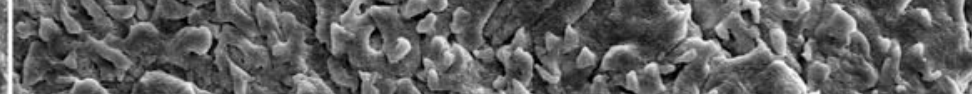

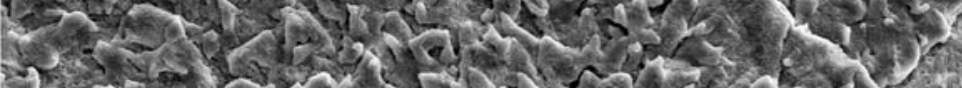

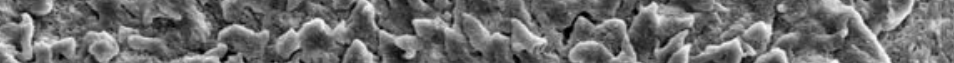

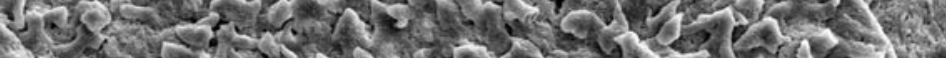

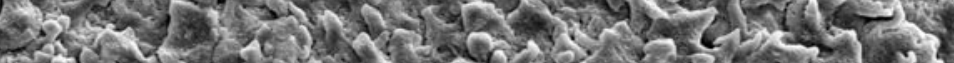

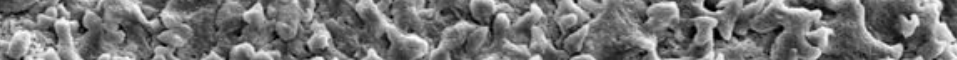

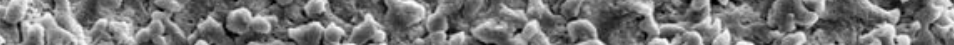

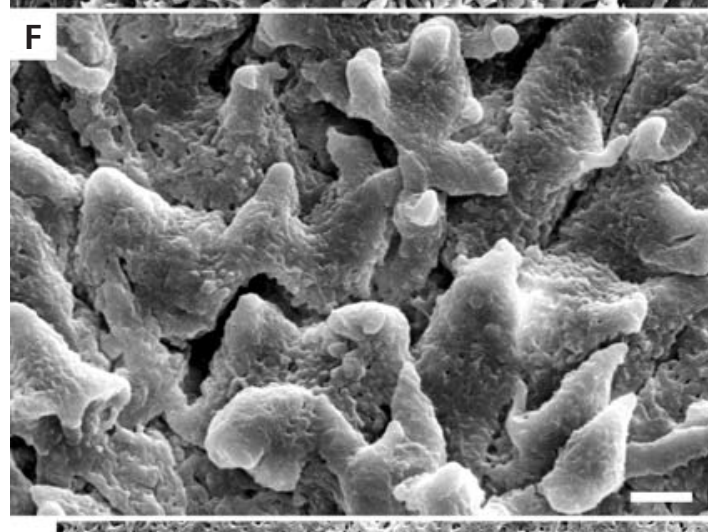

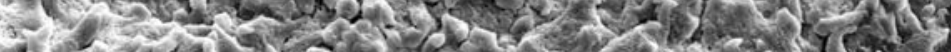

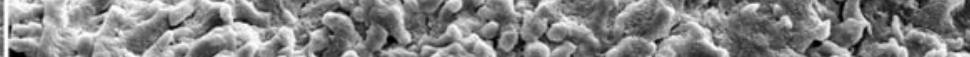

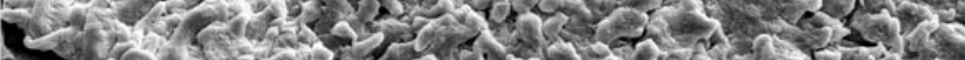

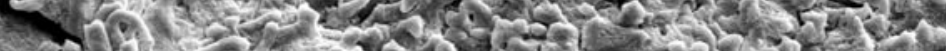

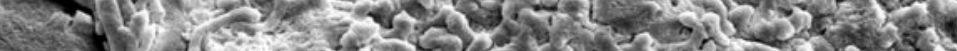

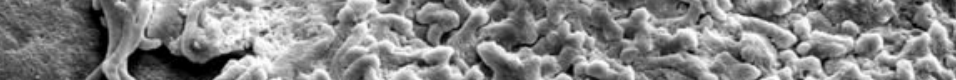

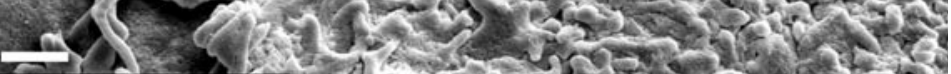

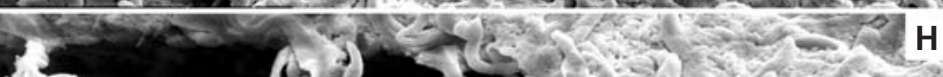

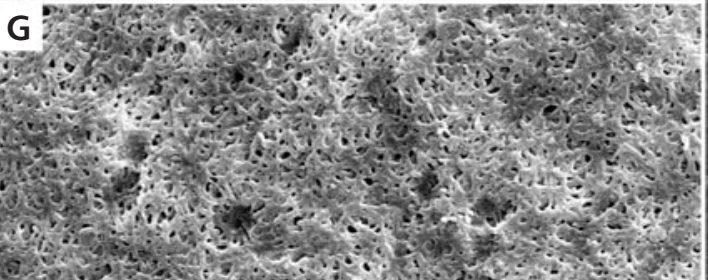
1.9.

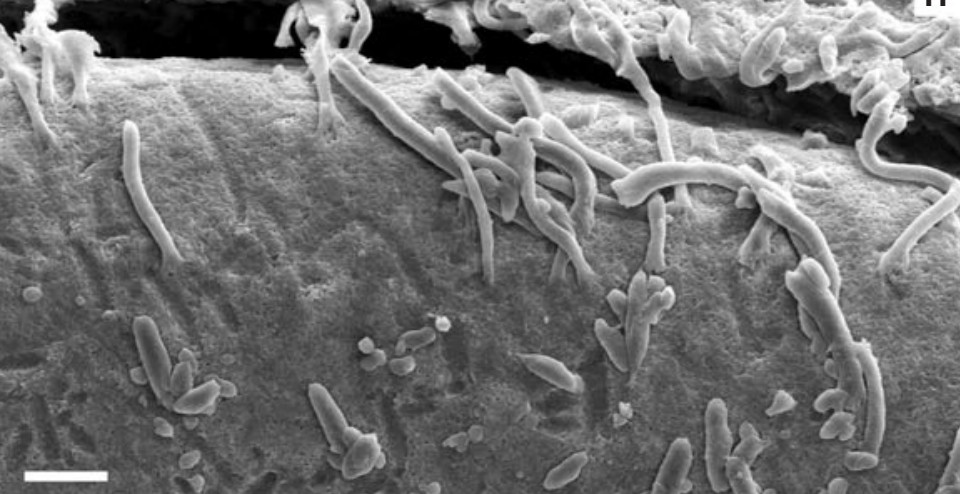


Smithonian Institution, Washington D.C., USA, for comparison with other Omphalophloios megaspores and confirmed, that these megaspores belong to Superbisporites dentatus [synonymum to Rotatisporites ramosus (Arnold) Potonié \& Kremp according to Dybová-Jachowicz et al. 1977]. These megaspores are illustrated in Fig. 28.

New specimens of Omphalophloios sp. nov. from the late Bolsovian of USA including in situ micro- and megaspores were studied by the authors (Opluštil et al. in prep.). Microspores are closely similar to all other in situ Omphalophloios microspores, i.e. they belong to the genera Densosporites and Cristatisporites. Megaspores (Fig. 29) are of the different type and can be correlated with the dispersed spore species Zonalesporites brasserti. Megaspores isolated from Omphalophloios cyclostigma differ from all other Omphalophloios megaspores.

Dispersed species Rotatisporites dentatus (syn. to Triletes ramosus) occurs from the Upper Namurian to Duckmantian in the USA (Arnold 1950, Winslow 1959) and its in situ record expands its stratigraphical range to the Asturian.

Megaspores for the comparison with Czech specimens were isolated from Omphalophloios from Puertollano, Spain (ZŠ 537 and E390, Emma Mine, III ${ }^{\text {rd }}$ Seam). These megaspores possess more developed and compact coronae compared to those of $O$. feistmanteli. Small appendages do not occur on the distal pole. The comparison of appendages from $O$. feistmantelii, $O$. cyclostigma and $O$. sp. nov. is seen in Fig. 30. Generally megaspores isolated from Omphalophloios from Puertollano (Fig. 27) differ from all other Omphalophloios megaspores except for $O$. feistmantelii. They are only roughly similar and may be compared with the dispersed spore species Zonalesporites superbus and Zonalesporites anguitextus Bharadwaj. It is possible to classify them as Zonalesporites cf. superbus.

Sometimes it is possible to observe microspores of the genus Densosporites lying on the surface of their female counterpart, megaspores of the Zonalesporites superbus-type (Fig. 18F).

\section{Comparison}

The genus Omphalophloios represents conservative type of sub-arborescent lycopsid that did not change significantly during the Pennsylvanian. The dominant image of
Omphalophloios is the same for all species - a large leafy axis with sporangia borne in fertile zones along its length. This is exactly the same for $O$. feistmantelii described herein and $O$. puertollanense from the late Stephanian $\mathrm{C} /$ Autunian of central Spain. Both species are preserved in whitish volcanic ash, which buried them in situ, and they therefore display very similar modes of the preservation (Wagner 1989, Opluštil et al. 2007). One of differences is the generally larger size of $O$. puertollanense. Figured specimens as well as specimens from Puertollano stored in the National Museum, Prague, indicate the general absence of axes thinner than $20 \mathrm{~mm}$ and the common occurrence of axes thicker than $200 \mathrm{~mm}$. The larger only rarely occurs in specimens of $O$. feistmantelii. The larger habitat of $O$. puertollanense is reflected also in the larger size of its sporangia, which are about $10 \mathrm{~mm}$ in diameter (compared to $5-6 \mathrm{~mm}$ in the case of $O$. feistmantelii). However, the morphology of sporangia, cuticles, laminae and the fertile axis as a whole are the same. Even disarticulation stages, including naked axes with adhered pedicels (so-called Puertollania), are indistinguishable. Certain differences were observed in the morphology of the leaf cushions of vegetative stems. Both species have rhomboidal leaf cushions of the same length (about 16-18 mm), however, those of $O$. puertollanense are usually about $2 \mathrm{~mm}$ wider and lateral angles are more rounded. Another difference is the position of leaf scars. Although their shape and size are similar for both species, their position within the leaf cushion is slightly different. In the case of $O$. feistmantelii the leaf scar is about in the middle of the cushion length where the cushion reaches its maximum width, whereas $O$. puertollanense has leaf scars in the upper part of the leaf cushion above its maximum width. Unfortunately, even spores do not provide any reliably distinct features. The microspores (densospores) of Omphalophloios are of extremely variable morphology, which excludes their use for the recognition of particular species (Bek \& Straková 1995).

Comparison with the Duckmantian species, O. orzeschensis (includes former Bode's species Sporangiostrobus orzeschensis and S. rugosus) from the Upper Silesian Coal Basin meets with similar problems. Fragments of their fertile zone are morphologically and palynologically indistinguishable from $O$. feistmantelii. The only difference was found when comparing leaf cushions of the vegetative stem of $O$. feistmantelii and newly described species O. bodei Opluštil et al. 2010 (very probably the

Figure 30. Comparison of distal projections of in situ megaspores from Omphalophloios feistmantelii (O. Feistmantel) comb. nov. emend. (A-D), O. puertollanense (Remy \& Remy) Wagner (E), O. sp. (F) and O. cyclostigma (Lesquereux) (G); all × 500.・A - Břasy, Radnice Basin, NM E974. Original O. Feistmantel 1875-1876, plate LX, fig. 2. • B - Tuchlovice Mine, Kladno-Rakovník Basin. NM E2247 (coll. Kučera) (branched specimen). - C - Tuchlovice Mine, Kladno-Rakovník Basin, CGS ZŠ 474. • D - Filip II opencast Mine, Lubná near Rakovník, Kladno-Rakovník Basin. CGS ZŠ 478. - E - specimen ZŠ 537; loc. Puertollano, Emma opencast (Spain), Stephanian C/Autunian, Coal 3. • F - SI, 536592. • G - Omhalophloios cyclostigma (Lesquereux) White; SI 536593. 
Jiři Bek et al. • The sub-arborescent lycopsid Omphalophloios from the Middle Pennsylvanian of Bohemia
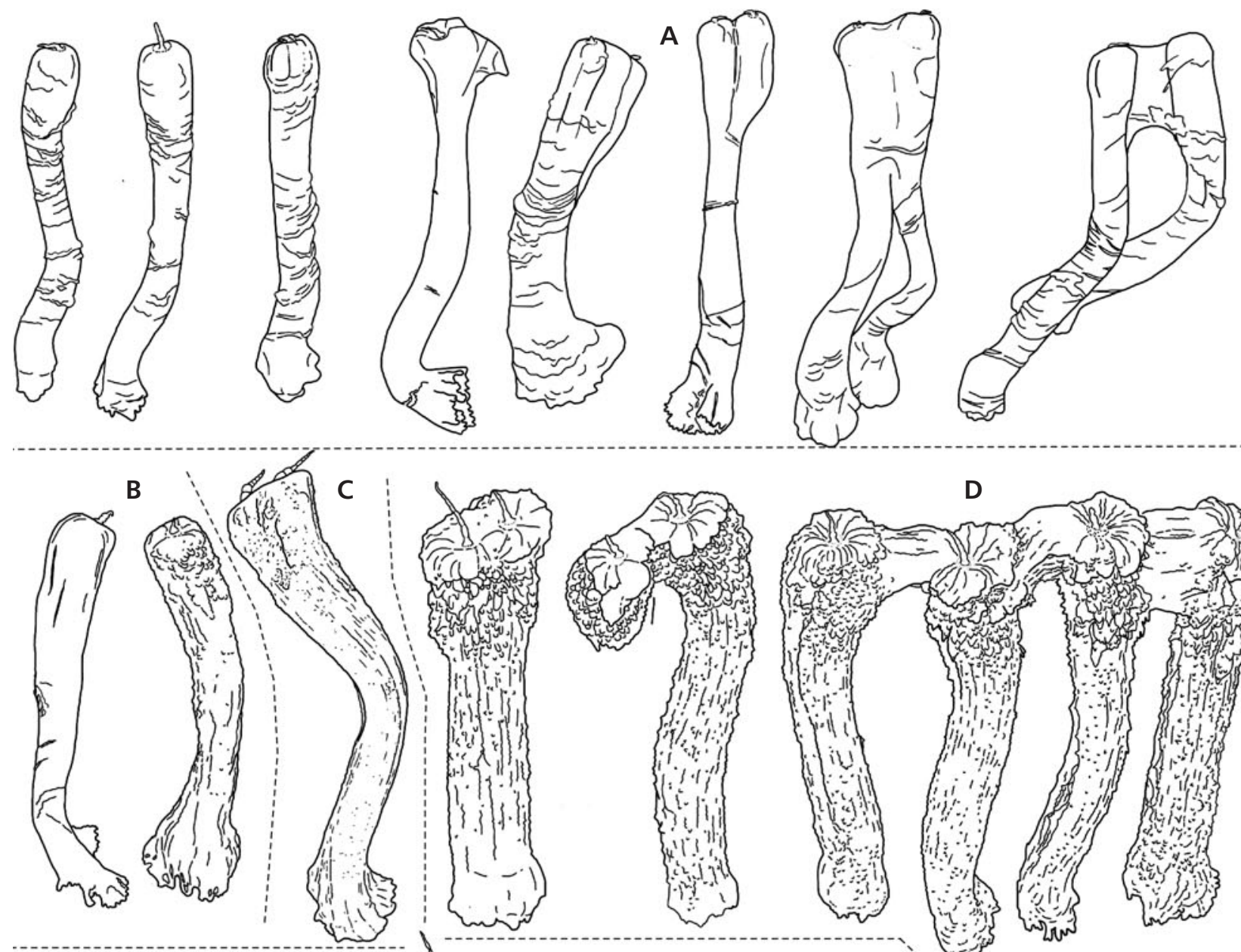

D
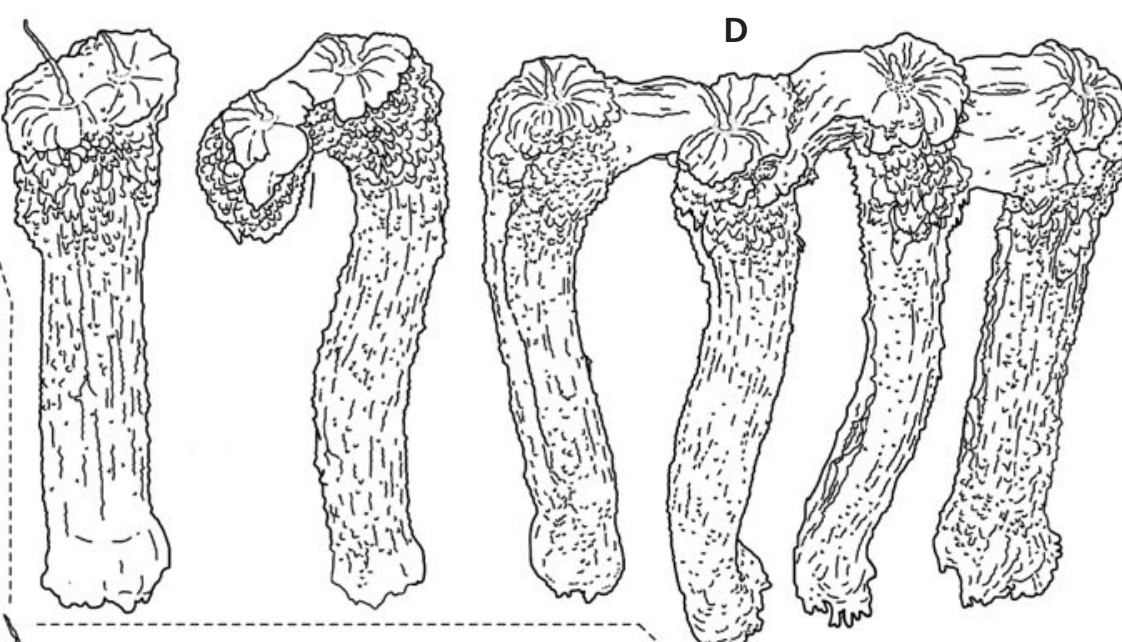

(t)

(C) (C)
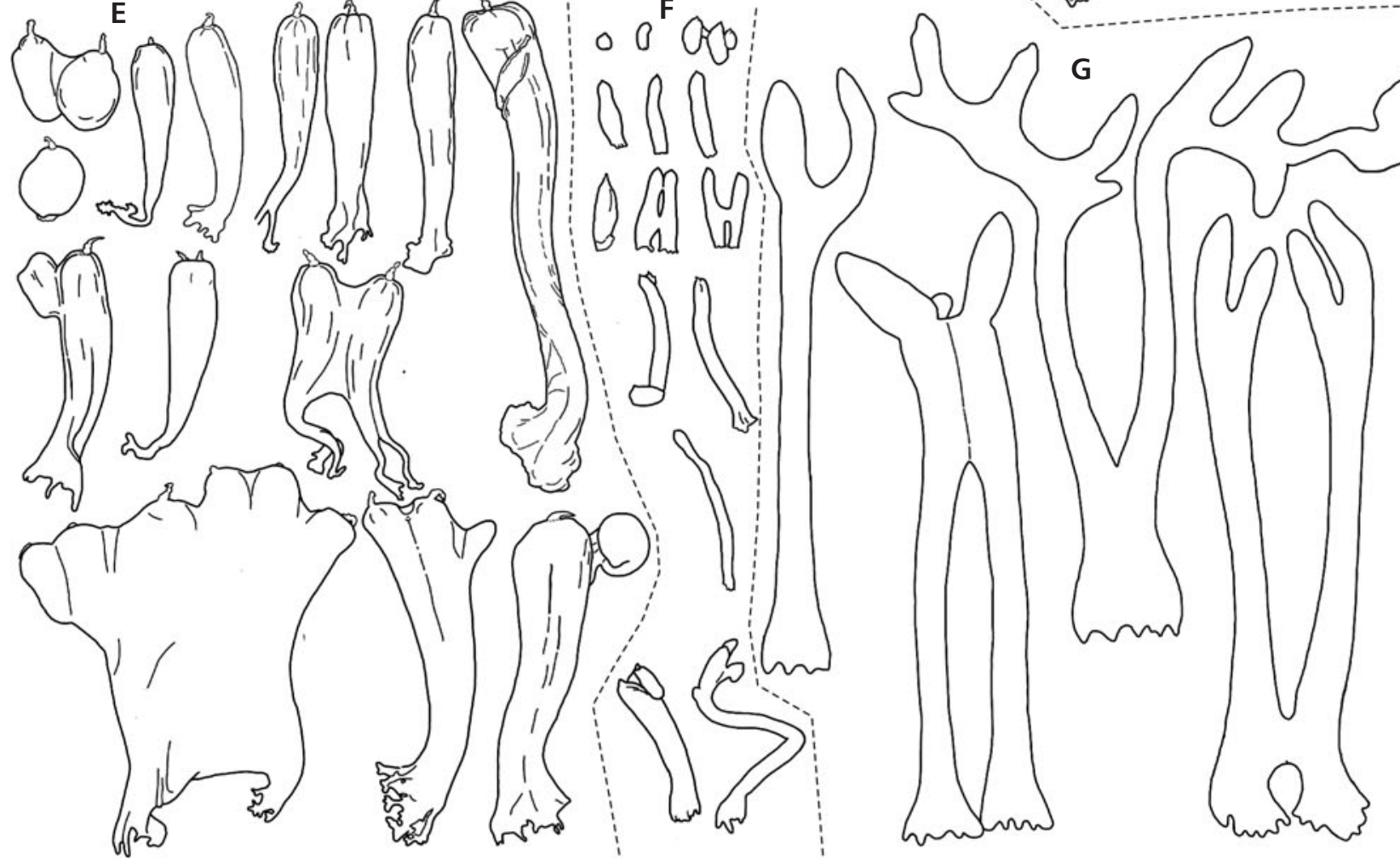
vegetative stem of $O$. orzeschensis). Those of the latter species are slightly smaller and generally wider and their lateral angles are more rounded. The length/width ratios are 3.4 and 2, respectively. The shape, size and position of leaf scar are the same for both species, i.e. in the middle of the length of the leaf cushion where the cushion reaches its maximum length.

The West European and North American species $O$. anglicus Sternberg and O. cyclostigma, both of Westphalian (Moscovian) age, seem to be slightly different concerning their habitus. Some bark fragments of these species are more than $200 \mathrm{~mm}$ wide and evidently represent a much larger form than $O$. feistmantelii. More over, their leaf cushions are wider and have rounded lateral angles in comparison to $O$. feistmantelii. New and rich but unpub- lished findings of Omphalophloios sp. nov. from the roof of the Lower Block Coal in the Illinois Basin stored in the collections of the Smithsonian Institution, Washington, USA and in the West Bohemian Museum, Pilsen, Czech Republic also proved that fertile axes of this species dichotomized several times resulting in terminal branches that are only about $15 \mathrm{~mm}$ wide. Unfortunately, the large variability of megaspores and microspores excludes their use for separation of all discussed species.

\section{The sporangial wall}

The character of the sporangial wall of Omphalophloios/Sporangiostrobus was well elaborated by Leisman

Figure 31. Specimens of Omphalophloios feistmantelii (O. Feistmantel) comb. nov. emend., which were used for the maceration of sporangial wall structures. • A - megasporangiate part of the fertile axis with attached distal laminae; Velká opuka tonstein, Tuchlovice mine, Kladno-Rakovník Basin; WBM F16317; scale bar $20 \mathrm{~mm}$. B - microsporangiate part of the fertile axis. Třemošná, Pilsen Basin; WBM F775; scale bar 10 mm. • C - fragment of microsporangiate part of the fertile axis; Kladno, Kladno-Rakovník Basin. WBM F7475; scale bar 10 mm. $\bullet$ D - fragment of microsporangiate part of the fertile axis; Kladno, Kladno-Rakovník Basin. WBM F7481; scale bar $10 \mathrm{~mm}$. E - megaporangiate part of the fertile axis with attached distal laminae; Velká opuka tonstein, Tuchlovice Mine, Kladno-Rakovník Basin. WBM F7486; scale bar $10 \mathrm{~mm}$. $\bullet \mathrm{F}$ - microsporangiate part of the fertile axis with attached distal laminae; Velká opuka tonstein, Tuchlovice Mine, Kladno-Rakovník Basin. WBM F7473; scale bar 10 mm. • G - fragment of microsporangiate part of the fertile axis; Kladno locality, Kladno-Rakovník Basin. WBM F7485; scale bar 10 mm. • H - fragment of microsporangiate part of the fertile axis; Kladno locality, Kladno-Rakovník Basin. WBM F7484; scale bar $10 \mathrm{~mm}$. $・$ I - fragment of microsporangiate part of the fertile axis; Kladno, Kladno-Rakovník Basin. WBM F7479; scale bar $10 \mathrm{~mm}$.

Figure 32. Omphalophloios feistmantelii (O. Feistmantel) comb. nov. emend. $\bullet$ A - one half of microsporangium showing visible attaching point (P) to pedicel; lines indicate dehiscence areas/bands (d). Třemošná, Pilsen Basin. WBM F775; SEM; scale bar 1 mm. • B - microsporangium with visible attachment point (P) to pedicel; lines indicate dehiscence areas/bands (d). Kladno, Kladno-Rakovník Basin. WBM F7473; SEM; scale bar 1 mm. - C - microsporangium with visible attachment point (P) to pedicel; lines indicate dehiscence areas/bands (d). Kladno, Kladno-Rakovník Basin. WBM F7473; SEM; scale bar $1 \mathrm{~mm}$. D - thickness of microsporangium cell wall with microspores; a line represents the boundary between spores and sporangial wall. Kladno, Kladno-Rakovník Basin. WBM F7484; SEM; scale bar $50 \mu \mathrm{m}$. • E - cutinised outer layer (O) and sporonised, reticulate tapetum (I) of microsporangium. Kladno, Kladno-Rakovník Basin. WBM F7485; SEM; scale bar 100 um. F _ "granulate" dehiscence area (d) with visible sclerenchymatous stripes. Třemošná, Pilsen Basin. WBM F775; SEM; scale bar 200 m. • G - detail of granulation (arrow). Třemošná, Pilsen Basin. WBM F775; SEM; scale bar $100 \mu \mathrm{m}$. $\bullet \mathrm{H}$ - inner side of cuticle $\left(\mathrm{X}_{1}\right)$ where outlines of cells are clearly visible and the outer side of cuticle $\left(\mathrm{X}_{2}\right)$ where the outlines of cells is indistinct. Kladno, Kladno-Rakovník Basin. WBM F7485; SEM; scale bar $100 \mu$ m. $\bullet$ I - fragment of cuticle from the dehiscence (arrow) on megasporangium area. Velká opuka tonstein, Tuchlovice Mine, Kladno-Rakovník Basin; WBM F7486, SEM; scale bar 200 $\mu$ m. - J - megasporangium with remains of cuticle of the outer sporangium wall (arrow). Velká opuka tonstein, Tuchlovice, Tuchlovice Mine, Kladno-Rakovník Basin. WBM F16317; SEM; scale bar $1 \mathrm{~mm}$. $\bullet \mathrm{K}$ - microsporangial cell wall consiting of cuticle, epidermis and inner layer shows slurred palisade-like cells (arrow); outer surface of sporangium is sporsed by disperse spores; above the inner layer are preserved microspores (ring). Kladno, Kladno-Rakovník Basin. WBM F7475 SEM; scale bar $20 \mu \mathrm{m}$. • L - fragment of sporangium wall (arrow) overlap megaspore. Velká opuka tonstein, Tuchlovice, Tuchlovice Mine, Kladno-Rakovník Basin. WBM F16317; SEM; scale bar $200 \mu \mathrm{m}$.

Figure 33. Omphalophloios feistmantelii (O. Feistmantel) comb. nov. emend. All figures are from microsporangia. • A- the cuticle of outer layer displaying conspicuous and well preserved cells $C_{2}$ type occupying the dehiscence area and the second type $C_{1}$ occupying the remaining area of the sporangium other surface; the line represents the boundary between $\mathrm{C}_{1}$ and $\mathrm{C}_{2}$ cell types. Kladno, Kladno-Rakovník Basin. WBM F7481; scale bar $400 \mu \mathrm{m} . \bullet \mathrm{B}$ - random, slightly elongate $\mathrm{C}_{1}$ type cells. Kladno, Kladno-Rakovník Basin. WBM F7481; scale bar $50 \mu \mathrm{m}$. $\bullet$ C - random, slightly elongate $\mathrm{C}_{1}$ type cells. Kladno, Kladno-Rakovník Basin. WBM F7487; SEM; scale bar $100 \mu \mathrm{m}$. $\bullet \mathrm{D}$ - random, elongate $\mathrm{C}_{2}$ type cells with sclerenchymatous strips. Třemošná, Pilsen Basin. WBM F775; SEM; scale bar $20 \mu \mathrm{m}$. • E - detail of random, elongate $\mathrm{C}_{2}$ type cells with sclerenchymatous strips. Kladno, Kladno-Rakovník Basin. WBM F7487; scale bar $20 \mu \mathrm{m}$. • F - a cell filled by very small honeycomb-like structures (?secretory cells). Kladno, Kladno-Rakovník Basin. WBM; SEM; scale bar $10 \mu \mathrm{m} . \bullet \mathrm{G}$ - needle-like shape of trichomatous papillae with extended base occur on the cells. Kladno, Kladno-Rakovník Basin. WBM F7479; SEM; scale bar $10 \mu \mathrm{m} . \bullet \mathrm{H}$ - laminar hydatodes are represented by thickened ellipse rim placing inside the some cells. Kladno, Kladno-Rakovník Basin. WBM F7487; SEM; scale bar $20 \mu \mathrm{m}$. $\bullet$ I - needle-like shape of trichomatous papillae with extended base occur on the cells. Kladno, Kladno-Rakovník Basin. WBM F7479; scale bar $20 \mu \mathrm{m}$. $\bullet \mathrm{J}$ - trichomatous papillae and thickened cells scattered on the epidermis. Kladno, Kladno-Rakovník Basin. WBM F7479; scale bar $50 \mu \mathrm{m}$. 

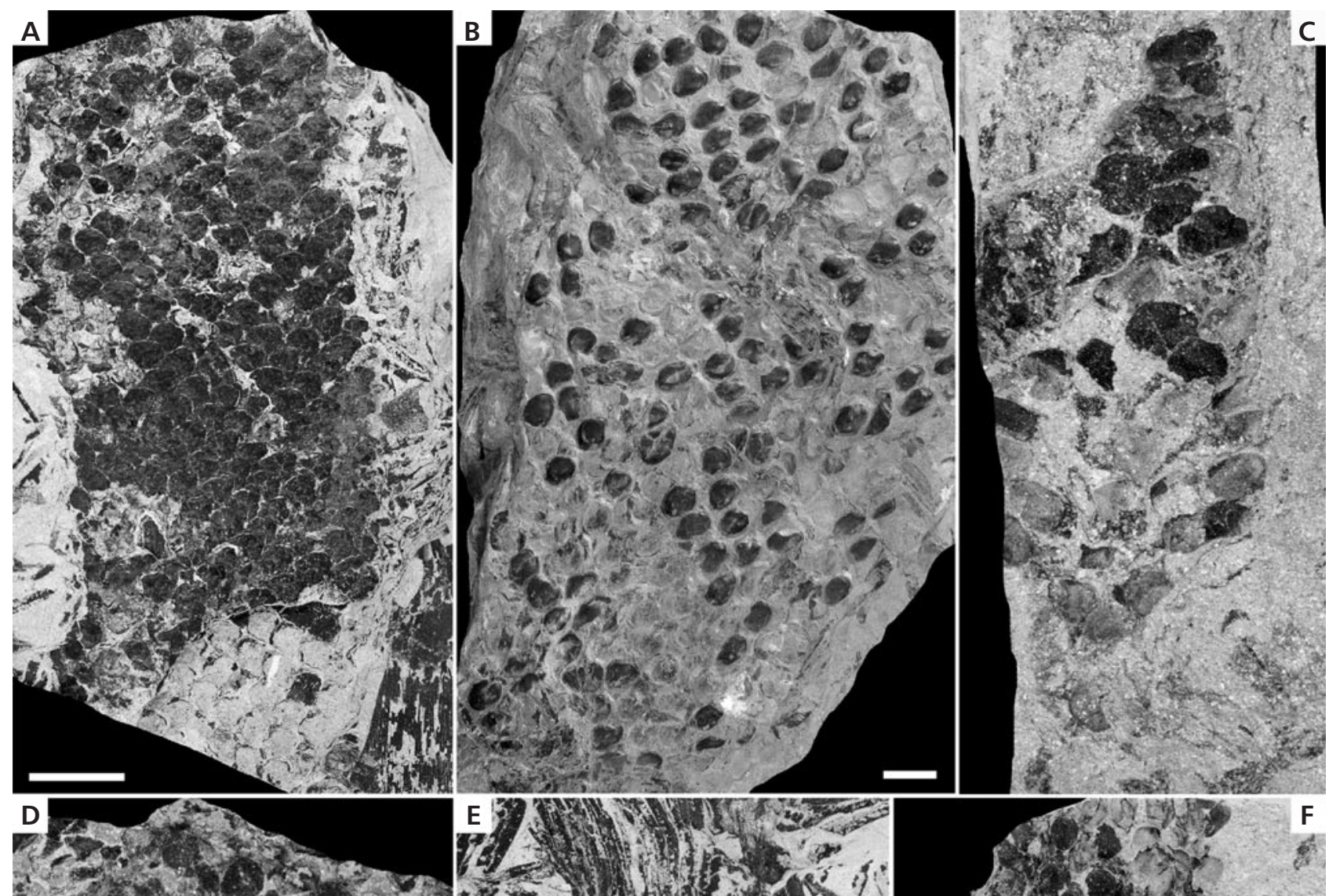

intege

E. 5 (1)

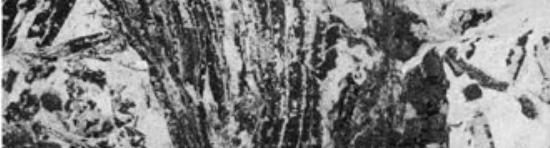
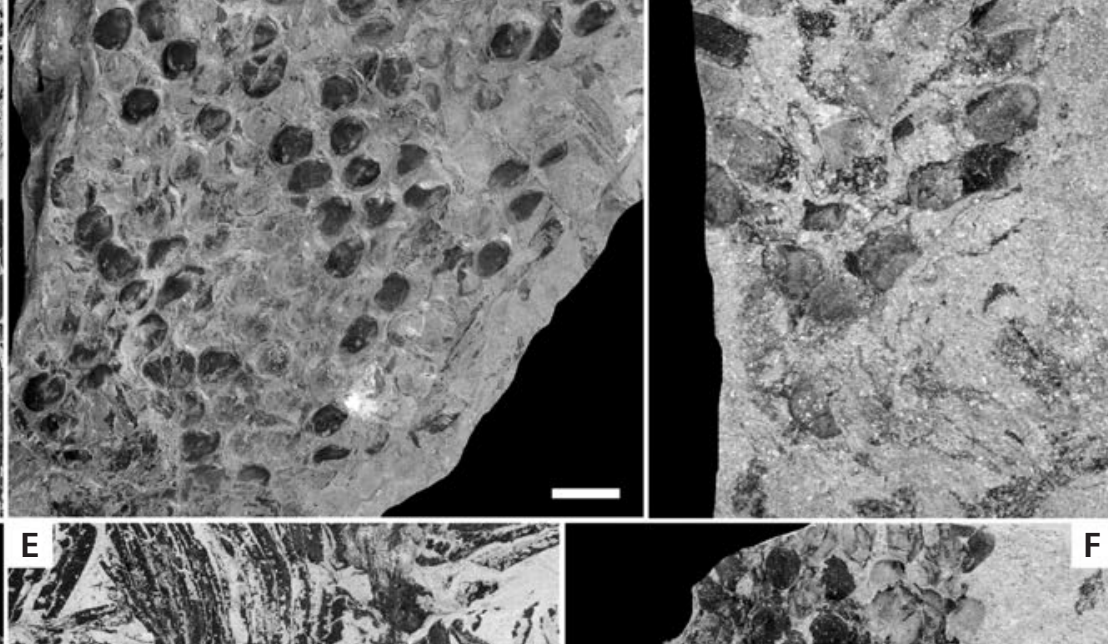
$\mathbf{F}$ 1) 1,120

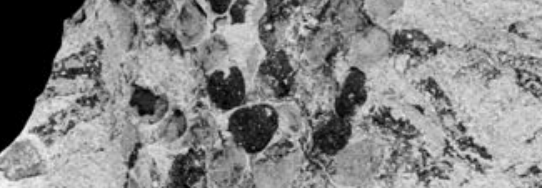

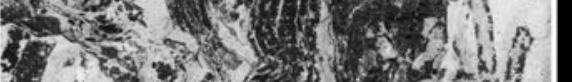

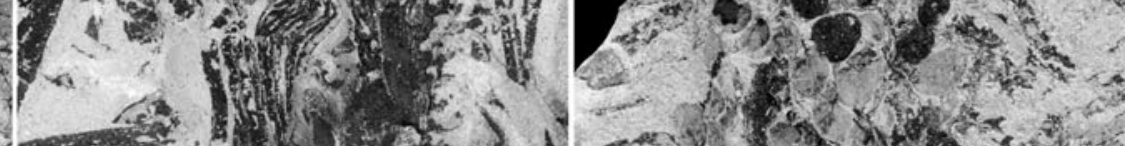

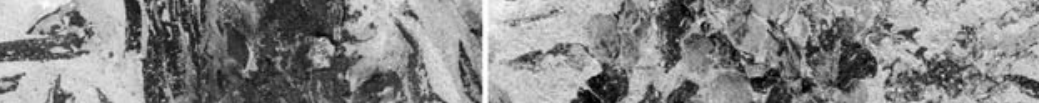

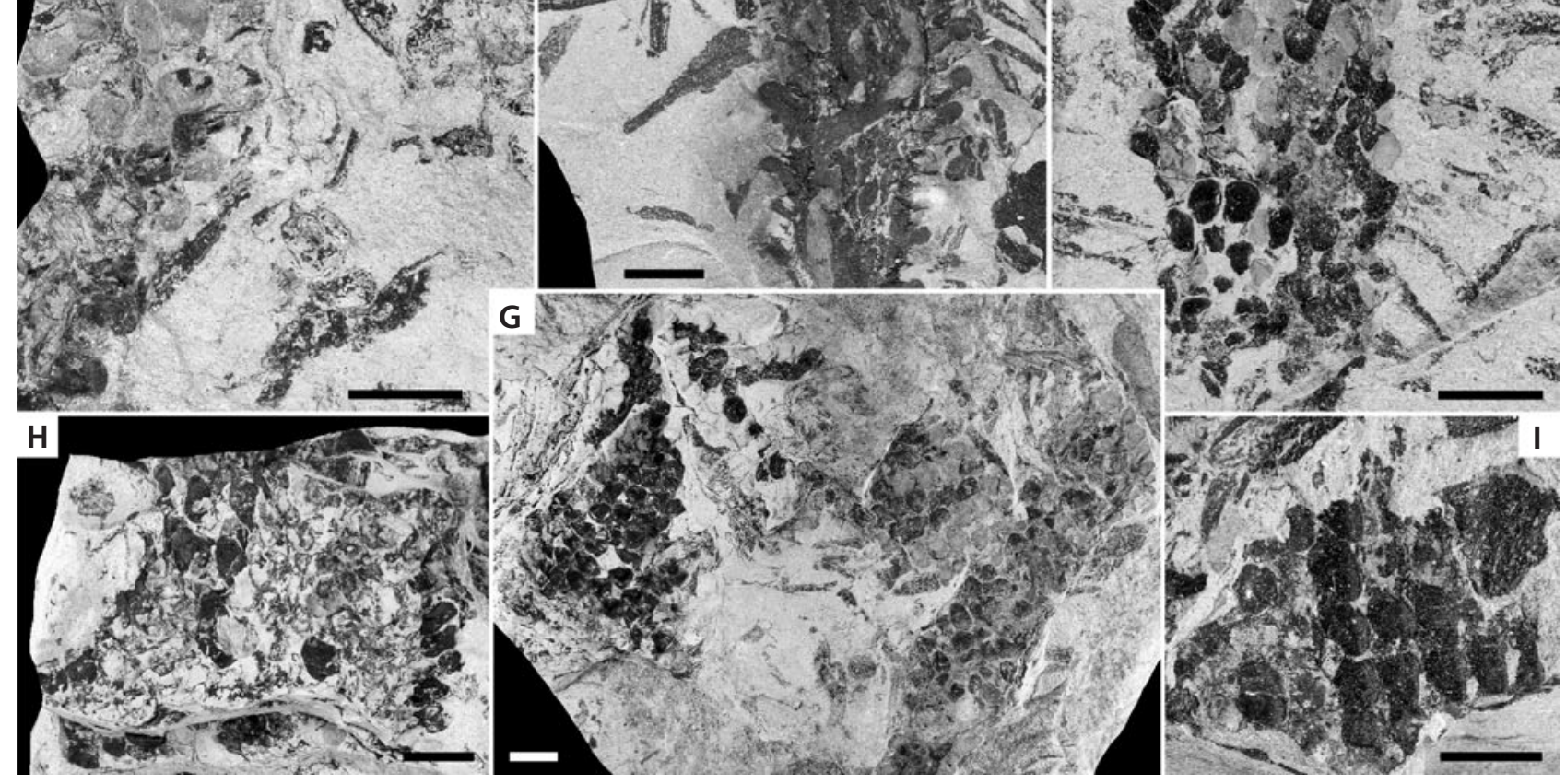



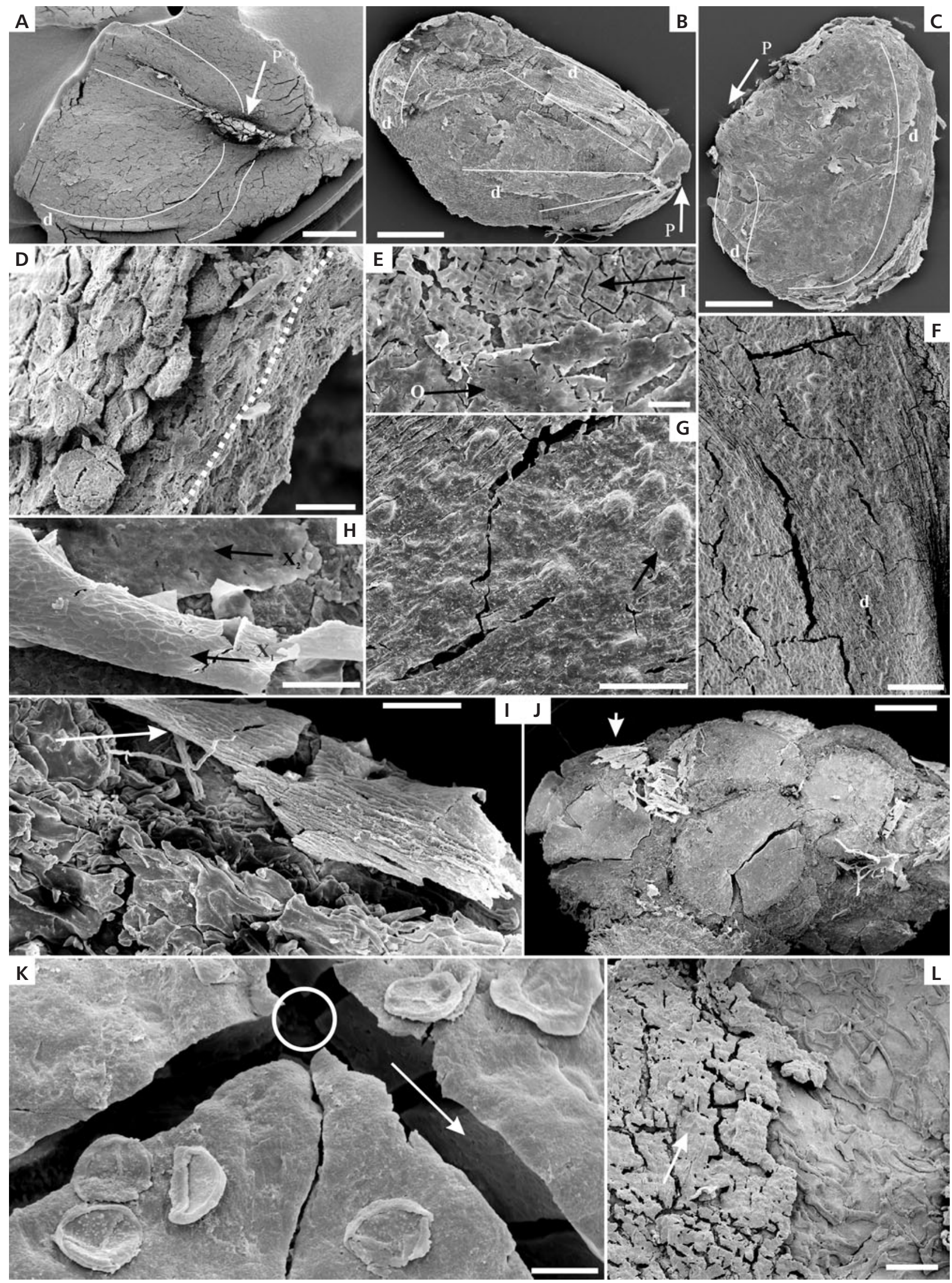

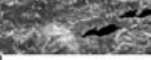
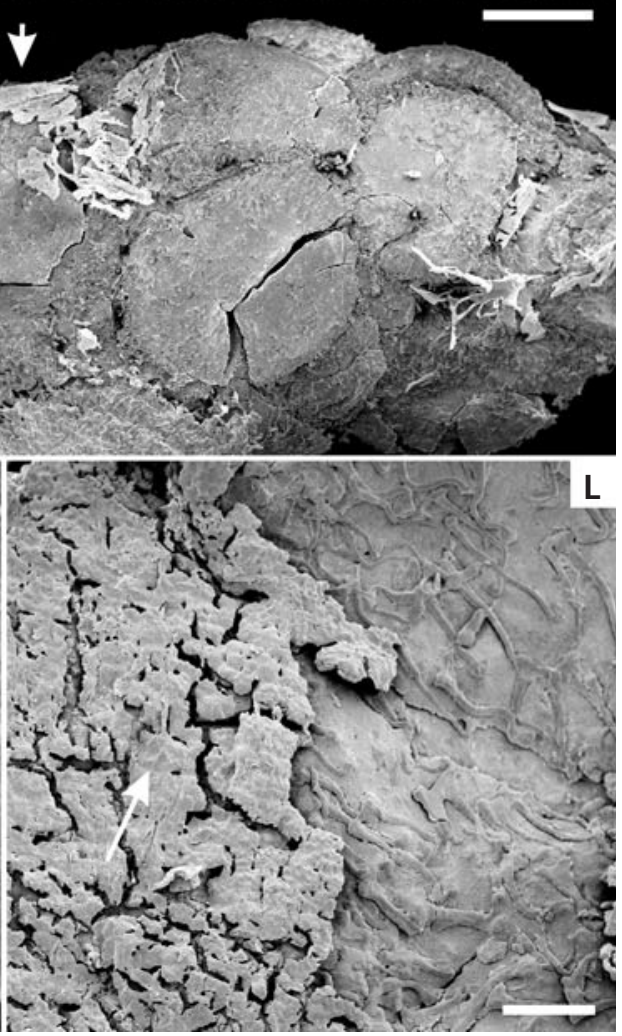


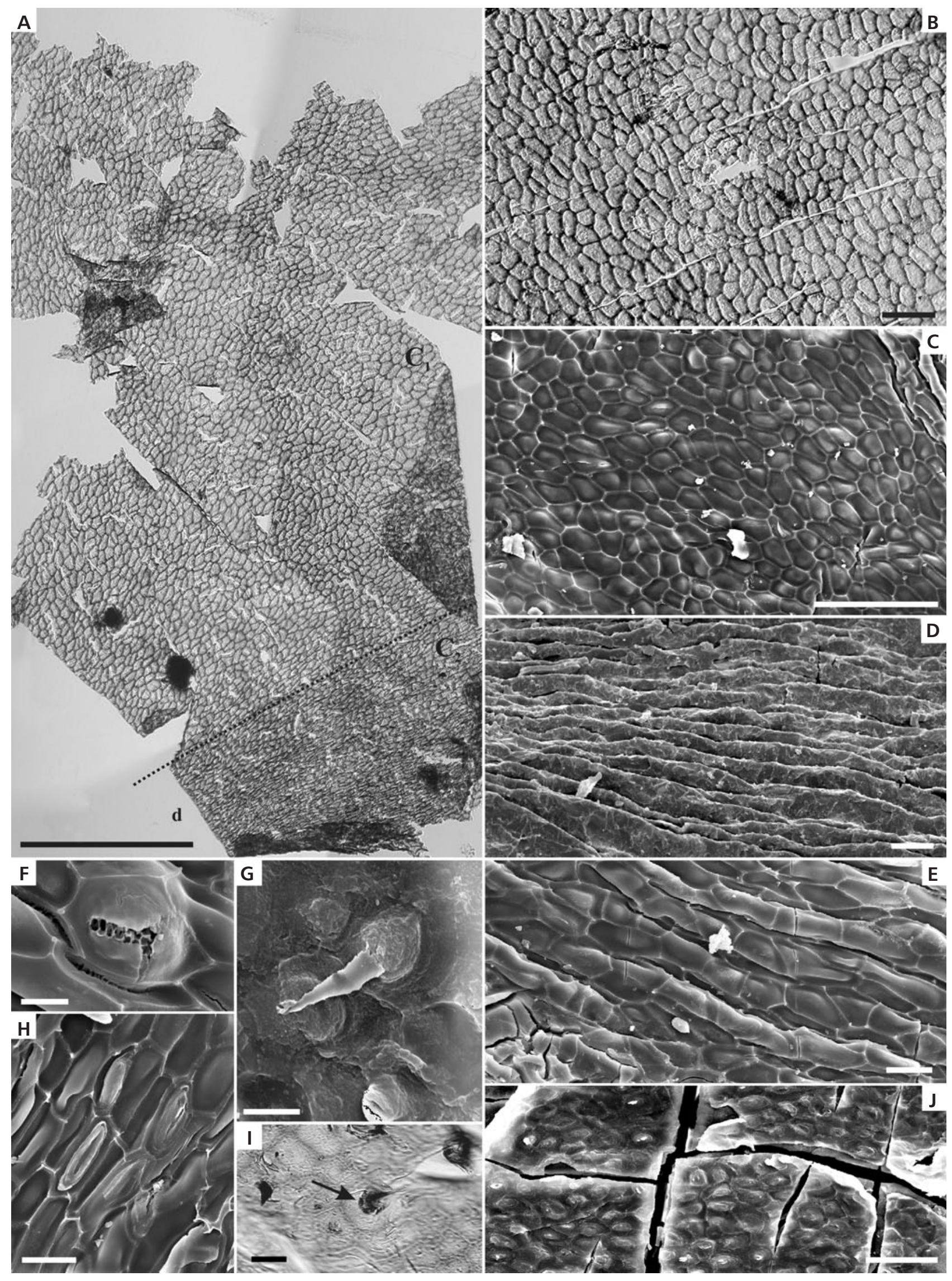


(1970) and Remy \& Remy (1975). Both stated that sporangial wall of Omphalophloios/Sporangiostrobus consists of two layers. The outer layer is formed by epidermal cells covered by cuticle and the thicker inner layer is formed by palisade/parenchyma cells. Remy \& Remy (1975) also mentioned that the tapetum remains between parenchyma and spores. $O$. feistmantelii also has two sporangial layers, that is clearly observed on microsporangia (Fig. 32E, K). Leisman (1970) and Remy \& Remy (1975) described the thickness of the inner layer (palisade/parenchyma cells) as 140-170 $\mu \mathrm{m}$ (Sporangiostrobus kansanensis) or 40-150 $\mu \mathrm{m}$ (S. purtollanensis). Leisman's (1970) material is petrified, which makes thickness data more reliable. The thickness of the sporangial layer of new sporangia is around $30 \mu \mathrm{m}$ (Figs 32D, K). Nevertheless, the thickness could have been altered by compression. Fig. 32K (arrow) shows distorted palisade-like cells, which compare with Leisman's (1970) fig. 5, pl. 36. Microsporangia of $O$. feistmantelii show a two-wall cell pattern similar to that of the Selaginella microsporangia described by Koller \& Scheckler (1986).

The detail of epidermal cells of Omphalophloios-type of sporangia is resulting from obtaining large pieces of cuticle from sporangia. Generally, we are able to recognize two types of cells: ordinary cells (our $\mathrm{C}_{1}$ type) and cells of the dehiscence area (our $\mathrm{C}_{2}$ type) (Fig. 33A). Němejc (1931) also figured both types of cells but he did not recognize which cuticle fragments come from which part of the sporangium. $C_{1}$ cells were figured by Němejc (1931, figs 9 , 10 and 12) and $C_{2}$ cells in his fig. 11. Němejc (1931) also mentioned sclerenchymatously thickened cells (Němejc, 1931, fig. 11; herein Figs 33D, E, 34A, C). These sclerenchymatously thickened cells are known only from O. feistmantelii. The sclerenchymatous strips are situated at the dehiscence band, placed in equatorial area of the sporangium. The broadest are in the distal part of the sporangium and toward the base of the sporangium the dehiscence band narrows. This opening mechanism may evoke the function of an annulus of leptosporangiate ferns. Similar structures are described by Koller \& Scheckler (1986) from microsporangia of extant Selaginella Beauvoir species. According to Koller \& Scheckler (1986) dehiscence in species of the living lycopsid Selaginella begins when cells of the mature microsporangium dry, causing a contraction of the outer layer of cells sufficient enough to split adaxial and abaxial valves apart. Neverthe- less, the sclerenchymatous strips, which are 100-200 $\mu \mathrm{m}$ wide, rather disrupt the dehiscence area into shreds. This is supported by the fact that only small fragments of cuticles are usually obtained from this area of sporangia after maceration.

Sclerenchymatous strips are associated with probable laminar hydathodes represented by water pores (Fig. 33H), which are described herein for the first time from Omphalophloios-type of sporangia.

The occurrence of trichomatous papillae (Fig. 33G, I) is mentioned for the first time in the Omphalophloios-type sporangia. Trichomatous papillae accompany the hydathodes in the dehiscence area of the sporangium and likely protected against desiccation by water loss through the permanent openings of hyadathode water pores.

Very interesting structures are round bodies filled by very small secretory cells (Fig. 33F). We can only speculate about their function. These cells could contain some oil or secondary chemical secretion, indirectly suggesting some kind of ecological interaction among animals and these plants.

Stomatal apparatuses have not been observed that corresponding with the observations of Němejc (1931), Leisman (1970), Remy \& Remy (1975) and Opluštil et al. (2010).

Concerning the genus Omphalophlois sensu lato, only fragmentary information exists about sporangial cell patterns, given in papers of Bode (1928), Němejc (1931), Chaloner (1956), Leisman (1970), Remy \& Remy (1975) and Opluštil et al. (2010). None of these authors mentioned anything about using sporangia structure in their systematic classification. Consequently, the relevant detailed information (such as the number of cell layers, cell pattern and opening mechanism) about sporangium cellwall character was often omitted or marginalized because the predominant opinion among botanists was that sporangial cell-wall character lacked taxonomical importance for lycopsids. The present study reflects the importance of such features as the number of cell layers, cell pattern and sporangial opening mechanism congruent with studies of the extant Selaginella species, which show that sporangial cell-wall character has value in taxonomical classification (Somers 1982, Koller \& Scheckler 1986). In neither of the cited papers did the authors mention some clearly specialized cells as an opening mechanism. Therefore, the precise function of sclerenchymatous strips must remain obscure.

Figure 34. Omphalophloios feistmantelii (O. Feistmantel) comb. nov. emend. All figures are from megasporangia. $\bullet$ A - random, elongate $\mathrm{C}_{2}$ type cells with sclerenchymatous strips. Kladno, Kladno-Rakovník Basin. WBM F16317; SEM; scale bar $50 \mu \mathrm{m}$. $\bullet$ B - outer layer with dehiscent area (d) and ordinary cells; the line represents boundary between both areas. Kladno, Kladno-Rakovník Basin. WBM F16317; SEM; scale bar $100 \mu \mathrm{m}$ • $\bullet \mathrm{C}-$ detail of random, elongate $\mathrm{C}_{2}$ type cells with sclerenchymatous strips. Kladno, Kladno-Rakovník Basin. WBM F16317; SEM; scale bar $20 \mu \mathrm{m}$. $\bullet \mathrm{D}-$ cells of C1 and C2 types; dehiscent area contains sclerenchymatous strips. Kladno, Kladno-Rakovník Basin. WBM F16317; scale bar $100 \mu$ m. 
Jiří Bek et al. • The sub-arborescent lycopsid Omphalophloios from the Middle Pennsylvanian of Bohemia

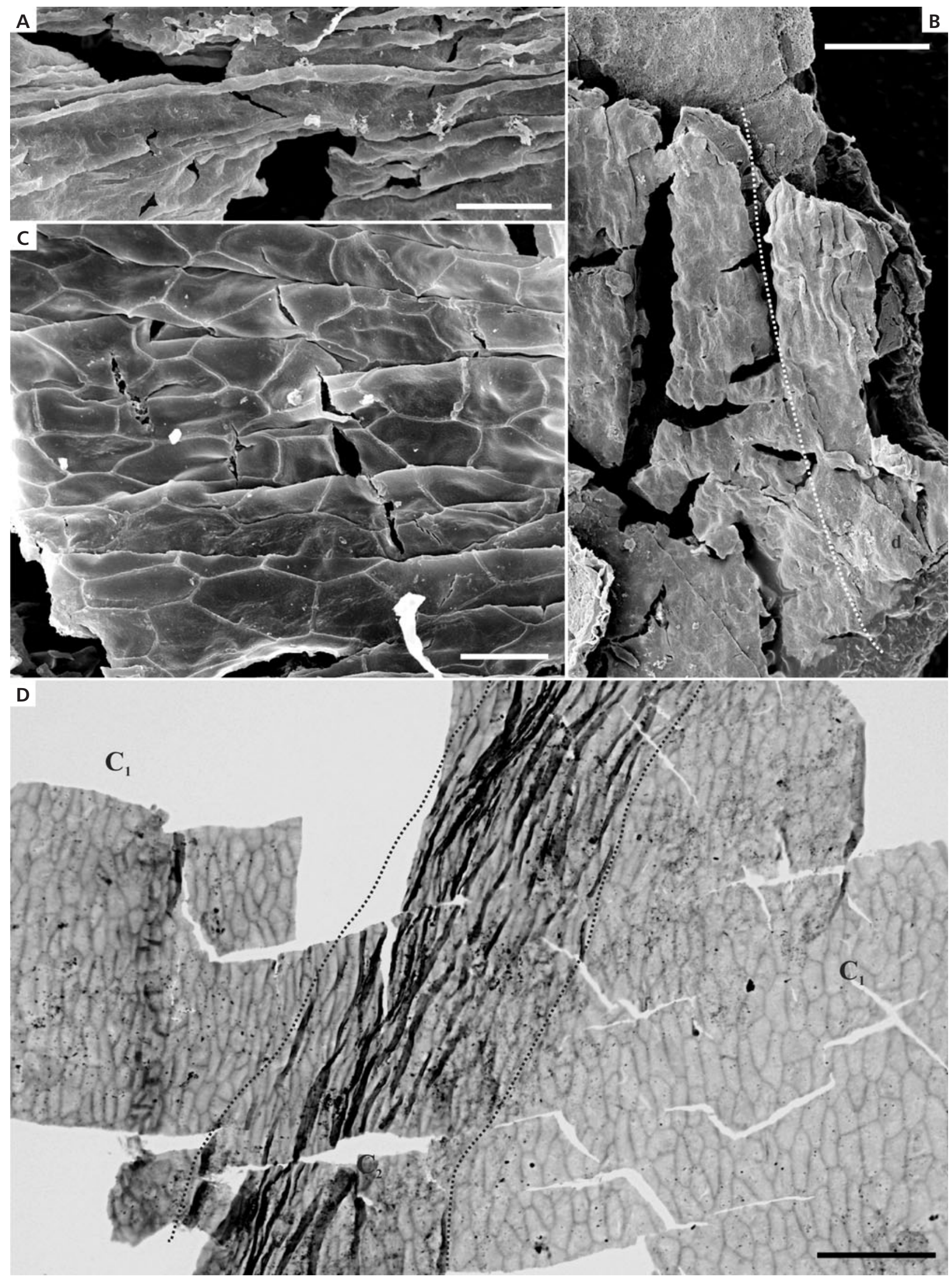




\section{Omphalophlois/Sporangiostrobus sporangia}

Bode (1928) described and figured only very poorly preserved sporangial cells of Sporangiostrobus (Omphalophloios) rugosus, which enabled him to state that cells are more or less polygonal, elongated and up to $40 \mu \mathrm{m}$ long and $20 \mu \mathrm{m}$ wide. He did not mention whether the cells came from microsporangia or megasporangia. The cells he described correspond with the $\mathrm{C}_{1}$ type of cells of micromegasporangia described herein, but unfortunately, no further comparison of the two species can be done because of limited information about the sporangial cell-wall composition of Bode's specimens.

Němejc (1931, figs 9-12) described sporangial cuticles of S. feistmantelii. He figured cuticles from micro- as well as megasporangia. Němejc (1931) only stated that cells are polygonal, cells of microsporangia are smaller than those of megasporangia, and mentioned strips of sclerenchymously thickened cell walls, which were observed on cuticles of the microsporangium (Němejc, 1931, fig. 11). The material described herein more or less corresponds with Němejc's (1931) observations.

Leisman (1970) described sporangial structures of S. kansanensis based on anatomically preserved specimens. Sporangial wall pattern and the type of cells more or less correspond except in thickness. The size of sporangia is also different; sporangia of $S$. kansanensis are $11 \mathrm{~mm}$ long and $7 \mathrm{~mm}$ wide whereas sporangia of Omphalophloios feistmantelii are 4-7 $\mathrm{mm}$ in diameter. Leisman (1970) also did not mention trichomatous papillae or any hydathodes on the body of the sporangium.

Remy \& Remy (1975) described in detail the sporangial structures of $S$. puertollanensis. The sporangial wall pattern and the type of cells more or less correspond to those described herein, except in thickness. Nevertheless, as in Leisman's description of S. kansanensis, Remy \& Remy (1975) did not mention trichomatous papillae or any hydathodes on the sporangial body.

Opluštil et al. (2010) described sporangial cell structures of Omphalophloios orzeschensis, which were observed under SEM, but without prior maceration. These authors stated that sporangial cells are elongate, polygonal, and varied between $30-40 \mu \mathrm{m}$ on average, which corresponds with the $\mathrm{C}_{1}$ type of cells described herein for both micro- and megasporangia.

\section{Ecology}

Although Omphalophloios is not the only densospore producer (Bharadwaj 1958, Chaloner 1962), Wagner (1989) suggested that the enormous size of its fructification predetermines it as the major producer of densospores in Euramerican tropical wetlands of Pennsylvanian time. We completely agree with this conclusion. This interpretation is strongly supported by the observation in the Puertollano Basin, Spain where Omphalophloios-bearing lower and upper tuff bands are present in both coal and associated carbonaceous mudstone (coal seam No. III) that contains 60 to $80 \%$ of densospores in the palynological assemblages (Wagner 1989). Similar observations were made on localities with $O$. feistmantelii in central Bohemia, Czech Republic. Here the remains of $O$. feistmantelii are very common in volcaniclastic bands (Velká opuka, Z-tuff) present within or capping coals dominated by densospores (Opluštil et al. 1999), but both the macrofossils and spores are extremely rare in mudstones in roof of the same coals. Abundant densospore content is also a common feature of many coal seams from Euramerican coalfields that lack fossiliferous tuff beds or coal balls and where remains of Omphalophloios are extremely rare or absent (e.g. Smith 1962, Butterworth 1966, Littke 1987, Strehlau 1990, Nowak \& Górecka-Nowak 1999). The only exception known to the authors is the Lower Block Coal in the Illinois Basin (SW Indiana, USA), the compression flora of which in roof mudstone is rich in remains of Omphalophloios. This is consistent with increased content (but not domination) of densospores in the roof of this coal (Mastalerz et al. 2000). It is worth noting that laminated mudstones in roof of this coal are interpreted by Kvale \& Archer (1990) as tidalite sediments that appear to have been deposited very rapidly. It is common to find trees $3 \mathrm{~m}$ or more in height, sometimes extending from the top of one coal bed to the bottom of the next. Thus, the roof rock of the Lower Block Coal probably captures the final vegetation of the peat swamp (DiMichele - pers. comm.).

To sum up these observations, the general rareness of Omphalophloios in clastic-sediment compression floras accompanying coal seams, on one hand, and their frequent occurrence in volcaniclastic bands within coal seams or carbonaceous mudstones dominated by densospores, on the other hand, points to the conclusion that Omphalophloios was a plant preferring peat and mixed peat-clastic swamps (Fig. 4). DiMichele \& Phillips (1994) suggest opportunistic strategy for this plant, which was able to rapidly colonize local habitats with limited competition. This interpretation is supported by observations that some Early to Middle Pennsylvanian coals are characterized by alternation of lycospore and densospore phases and that decrease of one group of spores is balanced by increasing content of the other group (e.g. Smith 1962, Opluštil et al. 1999, Bek 2008).

\section{Discussion on the whole plant reconstruction}

The current concept of the whole plant reconstruction of Omphalophloios is based on a large collection of specimens 

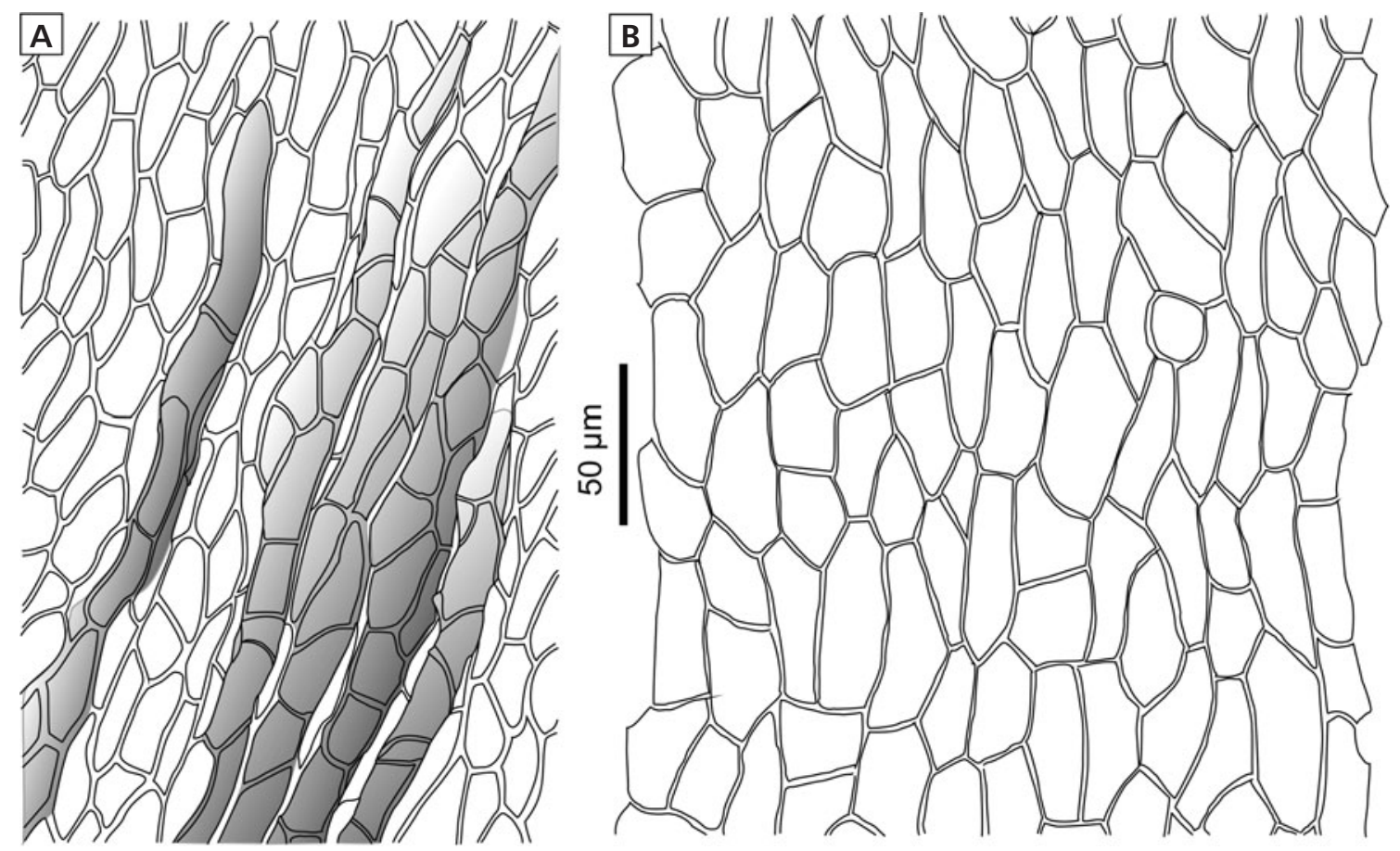

Figure 35. Omphalophloios feistmantelii (O. Feistmantel) comb. nov. emend. $\bullet \mathrm{A}-$ the cuticle of the outer layer displaying random, elongate cells $\mathrm{C}_{2}$ type occupies dehiscence area with sclerenchymatous strips (grey stripes). $\bullet \mathrm{B}$ - the cuticle of the outer layer displaying random, elongate cells $\mathrm{C}_{1}$ which occupying the sporangium surface except for the dehiscence area.

of O. puertollanense from Puertollano, Spain. Wagner (1989) assumes that this species was essentially a small columnar tree not taller than 3 to $5 \mathrm{~m}$ either unbranched or possibly with only one or two dichotomies at the top. Omphalophloios did not bear cones but its large rounded sporangia densely covered apical parts of the stem or branches. These fertile parts (apices) contain both micro- and megasporangia arranged in irregularly distributed patches that matured from the bottom to the top (Wagner 1989). In their reconstructions Wagner (1999) and Wagner et al. (2003) depict Omphalophloios with a relatively short fertile apex, not longer than about $1 / 5$ of the tree height. This is, however, in contradiction with the frequency of findings of fertile and vegetative parts since only about $6 \%$ of the Puertollano specimens (Wagner 1989) and 3\% of specimens from Bohemian localities preserve vegetative axes whereas the bulk of specimens are fragments of fertile zones. To explain this disproportion, Wagner (1989) suggested that partially disarticulated fertile apices were probably shed from the tree on maturity and that the growing tree would be capable of regenerating a fertile apex several times during its lifetime. Abscission of fertile apices could indeed result in their naturally increased concentration within plant litter preserved at the base of the tuff bed during a prolonged period of time. However, as Wagner (1989) argued, abscised or broken parts of Omphalophloios suffered from rapid decay, which explains why this plant litter consists mostly of disarticulated fragments. Specimens preserved in massive tuff bed (Wagner 1989, 1999; Wagner et al. 2003) are, however, not disarticulated or are only partly disarticulated remains, which indicates they were broken from living plants by the weight of volcanic ash. The association of remains resulting from this burial should therefore record the instantaneous ratio between fertile and sterile parts of plants at the time of the eruption. Therefore, an apparent contrast between the number of fertile and vegetative parts found both in Spanish and Czech localities leads us to the conclusion that the fertile zone does not necessarily abscise following sporangial/spore maturation and that the disproportion in abundance of both fertile parts is rather because the fertile segments of the Omphalophloios axes were much longer than its vegetative stem. Specimens of disarticulated fertile axes more than $250 \mathrm{~mm}$ long, of the Stage 3 preservation (Puertollania) grading into preservation stages 2 and 1, suggest rather gradual maturation of sporangia from the bottom to the top and their subsequent abscission from the plant, leaving the proximal parts of the sporophyll on the stem or branch. This interpretation is further supported by densospores of twice the diameter in sporangia far from the apex compared to those from apical sporangia (Bek \& Straková 1995).

The absence of finely divided dichotomous branches and large diameter of apical fragments led Wagner (1989) to conclude that $O$. puertollanense was essentially an unbranched tree perhaps with one or two dichotomies at the top. The scarcity of specimens showing dichotomous 
branching is principally true also for O.feistmantelii. Apart from $O$. puertollanense as some specimens of described species consist of preserved branches even less than $20 \mathrm{~mm}$ in diameter. Measurements of axes from the study collection also reveal diameters grouped into three more or less separate size classes (Fig. 2) suggesting that these represent axes produced by one or two or even more orders of apical dichotomy.

O. feistmantelii was probably only a small tree. The largest axis ever observed is $135 \mathrm{~mm}$ wide, however, axes greater than $70 \mathrm{~mm}$ in diameter are very rare. The whole plant was probably only 2 to $3 \mathrm{~m}$ tall on average. Material available allows us to partly reconstruct the ontogenetic development of $O$. feistmantelii (Fig. 3), except the juvenile stage, which can be assumed to have resembled juvenile stages of other arborescent lycopsids, especially lepidodendrids and sigillarians, as described by Phillips \& DiMichele (1992) or Opluštil (2010). In the early mature stage of development the plant had an unbranched collumnar stem that in its upper part started to produce sporangia (Fig. 3A), which when ripened released vast quantities of micro- and megaspores. It is not clear whether sporangia released spores when still attached to stem or after being shed. We can only state that mature parts of the fertile axis probably shed sporophyll laminae first and then sporangia, leaving the proximal parts of sporophylls (pedicels) on the stem. The shedding of the mature sporangia-bearing apex, as suggested by Wagner (1989), and its subsequent disarticulation releasing sporangia and finally spores does not seem to be the case for $O$. feistmantelii. Naked axes (disarticulation Stage 3), several tens of centimeters long, found both isolated and in connection with fertile apices still bearing complete sporophylls suggest gradual maturation and shedding of sporangia from the plant rather than abscission of the entire fertile apex. This interpretation is in agreement with the findings of non-disarticulated to disarticulated axes mostly in the middle and upper parts of the Z-tuff bed ( $40 \mathrm{~cm}$ thick). This bed preserves only plant fragments broken and buried due to the fall of volcanic ash, whereas plant litter was buried only in the basal few tens of millimeters of volcanic ash (Burnham \& Spicer 1986, Opluštil et al. 2009a). Therefore we assume that these fertile axes in various stages (1-3) of disarticulation had to be part of the still-living plant at the time of the volcanic ash fall.

The scarcity of dichotomizing fertile axis remains indicates that the fertile part of the stem could dichotomize only one or few times (Figs 3B, C). Either a dichotomized or simple columnar stem continued growth until the meristem ceased cell division, within the context of determinate growth. When the plant stopped growing, the remaining sporangia gradually matured and abscised and then the plant died leaving a naked Puertollania-type of axis. Such a late ontogenetic stage is probably represented by specimen E5625 (Fig. 6A), which shows only a $157 \mathrm{~mm}$ long fertile apex connected to a Puertollania-stage axis; ontogenetically younger fertile axes are much longer. Wagner (1989) discussed whether Omphalophloios was a monocarpic or polycarpic plant. Our specimens do support the idea of continuing reproduction because the sporangia appear to have matured up to the end of an individual plant's life cycle, suggested by the lack of an observed alternation of fertile and vegetative remains.

\section{Summary and conclusion}

An abundant collection of compressions of vegetative and fertile parts of the sub-arborescent lycopsid Sporangiostrobus feistmantelii from the middle Westphalian strata of central and western Bohemia, Czech Republic, provided a wealth of data for revision and reconstruction of the species. Specimens of this species, which is here assigned to the genus Omphalophloios due to priority, are mostly preserved in volcanic ash beds in which they were buried in situ. This simple burial history produced an association that contains remains of plants in various stages of maturation and/or disarticulation, often in organic connection. Such a unique taphocoenosis allows proposal of a hypothetical whole-plant reconstruction in various stages of maturity. The $O$. feistmantelii plant is estimated to be about 2 to $3 \mathrm{~m}$ tall, of columnar habit, the stem usually ones or twice dichotomizing. The basal vegetative part of the stem bears rhomboidal leaf cushions with a bell-shaped leaf scar. Most of the stem, however, bears densely spaced sporophylls with oval sporangia about $5-6 \mathrm{~mm}$ wide and $7-8 \mathrm{~mm}$ long. This suggests continuous reproduction from the time the plant reached maturity to the end of its life span. Fertile zones matured from bottom to top first shedding Cyperites-like laminae, which reached lengths of $>20 \mathrm{~cm}$, and then ripened sporangia, leaving only pedicels on the axis (Puertollania-disarticulation stage). The oldest parts of the stem decorticated leaving the stem in the Knorria-type of preservation.

From an ecological point of view, Omphalophloios plants preferred peat and mixed peat-clastic swamps and probably only exceptionally colonized habitats of mineral (clastic) substrate. This plant was able to colonize rapidly local habitats with limited competition (DiMichele \& Phillips 1994).

\section{Acknowledgement}

We acknowledge financial support from the Grant Agency of the Czech Republic via the project IAA210-12-2053. Part of this contribution was also supported by the Research Program of the Institute of Geology AS CR, v.v.i. (RVO67985831) and 
the Research Program PRVOUK P44 of the Faculty of Science, Charles University, Prague. The authors are also very grateful to M. Libertín (National Museum, Prague) and Z. Šimůnek (Czech Geological Survey, Prague) for providing access to the specimens in the collections of their institutions. The authors would like to express their best thanks to the reviewers, B.A. Thomas (Aberystwyth University, UK) and W.A. DiMichele (Smithsonian Institution, Washington, USA) for their useful critical remarks and creative comments on the manuscript and for their linguistic revision of the text. Thanks belong also to J. Svoboda who is an author of the reconstructions of Omphalophloios performed in Figs 3 and 4.

\section{References}

ARnold, C.A. 1950. Megaspores from the Michigan Coal Basin. Contribution from the Museum of Paleontology 8(5), 59-111. University of Michigan Press, Ann Arbor.

ARNold, C.A. 1961. Re-examination of Triletes superbus, T. rotatus, and T. mamillarius of Bartlett. Brittonia 13, 245-252. DOI 10.2307/2805340

Bartlett, H.H. 1928. Fossils of the Carboniferous Coal Pebbles of the glacial drift at Ann Arbor. Papers of Michigan Academy of Sciences, Letters 9, 11-28.

Bartling, F.G. 1830. Ordines naturales plantarum. 498 pp. Dieterich, Göttingen.

BARTRAM, K.M. 1987. Lycopod succession in coals: an example from the Low Burnley Seam (Westphalian B), Yorkshire, England, 187-199. In ScotT, A.C. (ed.) Coal and Coal-bearing strata: Recent advances. Geological Society, Special Publications 32.

BEK, J. 1998. Spórové populace některých rostlin oddělení lycophyta, sphenophyta, pteridophyta a progymnospermophyta z karbonských limnických pánví České republiky. 505 pp. Thesis, Institute of Geology AS CR, Praha.

BeK, J. 2008. Late Mississippian-early Pennysylvanian (Serpukhovian-Bashkirian) miospore assemblages of the Bohemian part of the Upper Silesian Basin, Czech Republic. Review of Palaeobotany and Palynology 152, 40-57.

DOI 10.1016/j.revpalbo.2008.04.008

Bek, J., Drábková, J., Dašková, J. \& Libertín, M. 2008. The sub-arborescent lycopsid genus Polysporia Newberry and its spores from the Pennsylvanian (Bolsovian-Stephanian B) continental basins of the Czech Republic. Review of Palaeobotany and Palynology 152, 176-199. DOI 10.1016/j.revpalbo.2008.05.002

BeK, J. \& Leary, R.L. 2012. Porostrobus nathorstii (Leary \& Mickle) emend. and its spores from the Namurian of Illinois, USA. Bulletin of Geosciences 87(1), 45-52. DOI 10.3140/bull.geosci.1293

BeK, J. \& Opluštil, S. 1998. Some lycopsid, sphenopsid and pteropsid fructifications and their miospores from the Upper Carboniferous of the Bohemian Massif. Palaeontographica, Abteilung B 248, 127-161.

Bek, J. \& StrakovÁ, M. 1995. Carboniferous fertile branch Sporangiostrobus feistmantelii (O. Feistmantel) Němejc and its miospores from the Kladno Basin, Bohemian Massif. Acta Musei nationalis Pragae, Serie B-historia naturalis 51, 37-51.
Berry, W. 1937. Spores from Pennington Coal, Rhea County, Tennessee. American Midland Naturalist 18, 155-160. DOI $10.2307 / 2420626$

Bharadwaj, D.C. 1958. On Porostrobus zeilleri Nathorst and its spores with remarks on the systematic position of $P$. benholdii Bode and the phylogeny of Densosporites Berry. The Palaeobotanists 7, 67-75.

Bode, H. 1928. Über eine merkwürdige Pteridophyten fruktifikation aus dem oberschlesien Carbon. Jahrbuch der Preußischen Geologischen Landesanstalt 49, 245-247.

Brousmiche-Delcambre, C., Coquel, R. \& Wagner, R.H. 1995. Nouvelle interprétation du genre Omphalophloios White, 1898 (Lycophyte primitive). Compte Rendu Academie des Sciences Paris 321, série IIa, 179-184.

Burnham, R.J. \& SPICER, R.A. 1986. Forest litter preserved by volcanic activity at El Chichón, Mexico. A potentially accurate record of the pre-eruption vegetation. Palaios 1(2), 16-28. DOI 10.2307/3514509

Butterworth, M.A., Jansonius, J., Smith, A.V.H. \& Staplin, F.L. 1964. Densosporites (Berry) Potonié and Kremp and related genera. Compte Rendu Congress Stratigraphique et Géologique du Carbonifère, Paris 1, 1049-1057.

Butterworth, M.A. 1966. The distribution of densospores. Palaeobotany 15(1-2), 16-28.

Chaloner, W.G. 1956. On Sporangiostrobus langfordii sp. nov., a new fossil lycopod cone from Illinois. American Midland Naturalist 55, 437-442. DOI 10.2307/2422605

Chaloner, W.G. 1962. A Sporangiostrobus with Densosporites microspores. Palaeontology 5(1), 73-85.

Chaloner, W.G. 1967. Lycophyta, 435-802. In Boureau, W.G., Høeg, O.A. \& Jovet-Ast, S. (eds) Traité de Paléobotanique 2. Masson et Cie, Paris.

Chaloner, W.G. 1999. Plants and spore compression in sediments, 36-40. In Jones, R.P. \& Rowe, N.P. (eds) Fossil Plants and Spores: Modern Techniques. The Geological Society Publishing House, Bath.

Coquel, R. \& Brousmiche-Delcambre, C. 1995. Comparaisons spores in situ-spores dispersées chez quelques Equisetales, Marattiales et Lépidodendrales du Carbonifère supérieur: Considérations sur l'utilisation de morphoespéces en paléopalynologie. Revue de Paléobiologie 15(1), 121-154.

Dettmann, M.E. 1963. Upper Mesozoic microfloras from southeastern Australia. Proceeding of Royal Society of Victoria 77, $1-148$.

DijkstrA, S. 1952. The stratigraphical value of megaspores. Comptes Rendus du Congrès d'Avances Etudes de la Stratigraphie et Géologie du Carbonifère, Heerlen 1, 163-168.

DiMichele, W.A. \& Phillips, T.L. 1994. Paleobotanical and paleoecological constraints on models of peat formation in the Late Carboniferous of Euramerica. Palaeogeography, Palaeoclimatology, Palaeoecology 106(1-4), 39-90.

DOI 10.1016/0031-0182(94)90004-3

Drábková, J., BeK, J. \& Opluštil, S. 2004. The first compression fossils of Spencerites (Scott) emend., and its isospores, from the Bolsovian (Pennsylvanian) of the Kladno-Rakovník and Radnice basins, Czech Republic. Review of Palaeobotany and Palynology 130, 59-88.

DOI 10.1016/j.revpalbo.2004.01.004

DybovÁ-Jachowicz, S., KarcZewska, J., LachKar, G., 
Loboziak, S. \& Evert, R.F. 2006. Esau's plant anatomy. 599 pp. Wiley and Sons Inc. USA.

Feistmantel, O. 1875-1876. Die Versteinerungen der Böhmischen Kohlenablagerungen. Palaeontographica 23, 223-262.

Glasspool, I.J., Hemsley, A.R., Scott, A.C. \& Golitsyn, A. 2000. Ultrastructure and affinity of Lower Carboniferous megaspores from the Moscow Basin, Russia. Review of Palaeobotany and Palynology 109, 1-31. DOI 10.1016/S0034-6667(99)00042-1

IBRAHIM, A.C. 1933. Sporenformen des Aegirhorizonts des Ruhr-Reviers. 47 pp. Konrad Triltsch, Würzburg.

Goldenberg, F. 1855-1862. Flora Saraepontana fossilis: Die Pflanzenversteinerungen des Steinkohlengebirges von Saarbrücken. 3 Heft. Saarbrücken.

KarcZewska, J. 1975. Megaspores of the Turma Zonales from the Carboniferous of Poland, Part 1. Coronate megaspores. Acta Palaeontologica Polonica 20, 447-500.

Koller, A. \& Scheckler, S.E. 1986. Variations in Microsporangia and Microspore Dispersal in Selaginella. American Journal of Botany 73(9), 1274-1288. DOI 10.2307/2444062

Kvale, E.P. \& ArCher, A.W. 1990. Tidal deposits associated with low-sulfur coals, Brazil Formation (Lower Pennsylvanian), Indiana. Journal of Sedimentary Petrology 60, $563-574$.

LeIsman, G.A. 1970. A petrified Sporangiostrobus and its spores from the middle Pennsylvanian of Kansas. Palaeontographica, Abteilung B 129(4-6), 166-167.

LeSQueReuX, L. 1880. Description of the coal flora of the Carboniferous formation in Pennsylvania and throughout the United States. Second Geological Survey of Pennsylvania, Report of Progress 1, 1-354.

LitTKe, R. 1987. Petrology and genesis of Upper Carboniferous seams from the Ruhr region, West Germany. International Journal of Coal Geology 7, 147-184. DOI 10.1016/0166-5162(87)90047-4

Mastalerz, M., Padgett, P.L. \& Eble, C.F. 2000. Block coal from Indiana: Inferences on changing depositional environment. International Journal of Coal Geology 43, 211-226. DOI 10.1016/S0166-5162(99)00060-9

NĚMEJC, F. 1931. A study on the systematic position of the fructification called Sporangiostrobus Bode. Bulletin international de l'Académie des Sciences de Bohême, 1-13.

NowaK, G.J. \& GóReCKA-NowaK, A. 1999. Peat-forming environment of Westphalian A coal seams from the Lower Silesian Coal Basin of SW Poland based on petrographical and palynological data. International Journal of Coal Geology 40, 327-351. DOI 10.1016/S0166-5162(99)00007-5

OpLuštiL, S. 2010. Contribution to knowledge on ontogenetic developmental stages of Lepidodendron mannebachense Presl, 1838. Bulletin of Geosciences 85(2), 303-316. DOI 10.3140/bull.geosci.1180

Opluštil, S., BeK, J. \& SchultKA, S. 2010. Re-examination of the genus Omphalophloios White, 1898 from the Upper Silesian Coal Basin. Bulletin of Geosciences 85(1), 123-136. DOI 10.3140/bull.geosci.1139

Opluštil, S., PšEniČKa, J., Libertín, M., Bashforth, A.R., ŠimưNEK, Z., DrábKovÁ, J. \& DAŠKovÁ, J. 2009a. A Middle Pennsylvanian (Bolsovian) peat-forming forest preserved in situ in volcanic ash: The Whetstone Horizon in the Radnice Basin, Czech Republic. Review of Palaeobotany and Palynology 155(3-4), 234-274.

DOI 10.1016/j.revpalbo.2009.03.002

Opluštil, S., PšeničKa, J., Libertín, M., BeK, J., DašKovÁ, J., ŠImƯneK, Z. \& DrábKová, J. 2009b. Composition and structure of an in situ Middle Pennsylvanian peat-forming plant assemblage in volcanic ash, Radnice Basin (Czech Republic). Palaios 24, 726-746. DOI 10.2110/palo.2008.p08-128r

Opluštil, S., PŠEničKa, J., Libertín, M. \& ŠImůnek, Z. 2007. Vegetation paterns of Westphalian and Lower Stephanian mire assemblages preserved in tuff beds of the continental basins of Czech Republic. Review of Palaeobotany and Palynology 143, 107-154.

DOI 10.1016/j.revpalbo.2006.06.004

Opluštil, S., SÝkorovÁ, I. \& BeK, J. 1999. Sedimentology, coal petrology and palynology of the Radnice Member in the S-E part of the Kladno-Rakovník Basin, Central Bohemia (Bolsovian). Acta Universitatis Carolinae, Geologica 43, 599-623.

PePPERS, R.A. 1996. Palynological correlation of major Pennsylvanian (Middle and Upper Carboniferous) chronostratigraphic boundaries in the Illinois and other coal basins. Geological Society of America, Memoirs 188, 1-119.

Phillips, T.L. \& DiMichele, W.A. 1992. Comparative ecology and life-history biology of arborescent lycopsids in Late Carboniferous swamps of Euramerica. Annals of the Missouri Botanical Garden 79(3), 560-588. DOI 10.2307/2399753

Phillips, T.L., Peppers, R.A., Avcin, M.J. \& Laughnan, P.F. 1974. Fossil plants and coal: Patterns of change in Pennsylvanian coal swamps of the Illinois Basin. Science 184, 1367-1369. DOI 10.1126/science.184.4144.1367

PigG, K.B. \& Rothwell, G.W. 1983. Chaloneria, gen. nov.: Heterosporous lycophytes from the Pennsylvanian of North America. Botanical Gazette 144, 132-147. DOI $10.1086 / 337354$

Potonié, R. \& Kremp, G. 1954. Die Gattungen der Paläozoischen Sporae dispersae und ihre Stratigraphie. Geologische Jahrbuch 69, 111-193.

Potonié, R. \& KRemp, G. 1955. Die Sporae dispersae des Ruhrkarbons ihre Morphographie und Stratigraphie mit Ausblicken auf Arten anderer Gebiete und Zeitabschnitte. Teil I. Palaeontographica, Abteilung B 98, 1-136.

Punt, W., Hoen, P.P., Blackmore, S., Nilsson, S. \& LeThomas, A. 2007. Glossary of pollen and spore terminology. Review of Palaeobotany and Palynology 143, 1-81.

DOI 10.1016/j.revpalbo.2006.06.008

REMY, W. \& REMY, R. 1975. Sporangiostrobus puertollanensis n. sp., und Puertollania sporangiostrobifera n. gen., n. sp. aus dem Stefan von Puertollano, Spanien. Argumenta Palaeobotanica 4, 13-29.

Rex, G.M. \& Chaloner, W.G. 1983. The experimental formation of plant compression fossils. Palaeontology 26, 231-252.

ScotT, D.H. 1909. Studies in Fossil Botany. $2^{\text {nd }}$ edition. 552 pp. A. \& C. Blafl Ltd., London.

SMith, A.H.V. 1962. The palaeoecology of Carboniferous peats based on the miospores and petrography of bituminous coals. Proceeding of Yorkshire Geological Society 33, 423-474. DOI 10.1144/pygs.33.4.423 
Smith, A.H.V. \& Butterworth, M.A. 1967. Miospores in the coal seams of the Carboniferous of Great Britain. Special Papers in Palaeontology 1, 1-324.

Somers, P. 1982. A unique type of microsporangium in Selaginella series Articulate. American Fern Journal 72(3), 88-92. DOI $10.2307 / 1546603$

SPINNER, E. 1965. Westphalian D megaspores from the Forest of Dean Coalfield, England. Palaeontology 8(1), 82-106.

STERNBERG, K. 1823. Versuch einer geognostich-botanischen Darstellung der Flora der Vorwelt. Vol. I, part 3.40 pp. E. Brenck's Wittwe, Regensburg.

Strehlau, K. 1990. Facies and genesis of Carboniferous coal seams of Northwest Germany. International Journal of Coal Geology 15, 245-292.

DOI 10.1016/0166-5162(90)90068-A

WAGNER, R.H. 1983. Late Westphalian D and early Cantabrian floras of the Guardo Coalfield. Geology and Palaeontology of the Guardo Coalfield (NE León-NW Palencia), Cantabrian Mts.: Serie Informes Instituto Geológico y Minero de España, 57-91.

WAGNER, R.H. 1989. A late Stephanian forest swamp with Sporangiostrobus fossilized by volcanic ash fall in the Puertollano Basin, central Spain. International Journal of Coal Geology 12, 523-552. DOI 10.1016/0166-5162(89)90064-5
WAGNER, R.H. 1999. Macroflora del carbonífero/pérmico, 77-98. In Aguirre, E. \& RÁbAno, I. (eds) La huella del pasado. Fósiles de Castilla-la Mancha. Património histórico, Arquelogía Castilla-La Mancha, Junta de Comunidades de Castilla-La Mancha, Toledo.

Wagner, R.H., Brousmische-Delcambre, C. \& Coquel, R. 2003. Una Pompeya Paleobotánica: historia de una marisma carbonífera sepultada por cenizas volcánicas, 448-475. In Nuche, R. (ed.) Separata de Patrimonio Geológico de Castilla-La Mancha. Enresa, Madrid.

WAGNER, R.H. \& SPINNER, E. 1976. Bodeodendron, tronc associé à Sporangiostrobus. Comptes rendus, Académie des Sciences, Paris, Série D, Sciences naturelles 282, 353-356.

White, D. 1898. Fossil flora of the Lower Coal Measures of Missouri. Monographs of the United States Geological Survey 37, $1-467$.

WinsLow, M.R. 1959. Upper Mississippian and Pennsylvanian megaspores and other plant microfossils from Illinois. Bulletin of the Illinois State Geological Survey 86, 7-13, 5.1959.

Zavialova, N. \& TuRnau, E. 2012. Morphology and wall ultrastructure of some Middle Devonian dispersed megaspores from northern Poland. Review of Palaeobotany and Palynology 171, 103-121.

DOI 10.1016/j.revpalbo.2011.12.001 